UNIVERSIDADE DE SÃO PAULO

INSTITUTO DE PSICOLOGIA

GABRIEL CASTRO SIQUEIRA

Noções de bem viver latino-americanas na perspectiva da psicologia:

uma revisão de escopo

São Paulo

2020 
GABRIEL CASTRO SIQUEIRA

\section{Noções de bem viver latino-americanas na perspectiva da psicologia:}

uma revisão de escopo

\section{Versão Original}

Dissertação apresentada ao Programa de Pós-Graduação em Psicologia Social do Instituto de Psicologia da Universidade de São Paulo para obtenção do título de Mestre em Psicologia

Área de concentração: Psicologia Social e do Trabalho

Orientador: Prof. Livre-Docente Alessandro de Oliveira dos Santos 
Autorizo a reprodução e divulgação total ou parcial deste trabalho, por qualquer meio convencional ou eletrônico, para fins de estudo e pesquisa, desde que citada a fonte.

Catalogação na publicação

Serviço de Biblioteca e Documentação

Instituto de Psicologia da Universidade de São Paulo

Siqueira, Gabriel Castro

Noções de bem viver latino-americanas na perspectiva da psicologia: uma revisão de escopo / Gabriel Castro Siqueira ; orientador, Alessandro de Oliveira dos Santos. - 2020

Dissertação (Mestrado em Psicologia) - Programa de PósGraduação em Psicologia Social - Instituto de Psicologia, Universidade de São Paulo, São Paulo, 2020

1. Bem viver. 2. Psicologia social . 3. Qualidade de vida. 4. Revisão de escopo. 
Nome: SIQUEIRA, Gabriel Castro

Título: Noções de bem viver latino-americanas na perspectiva da psicologia: uma revisão de escopo

Dissertação apresentada ao Programa de Pós-Graduação do Instituto de Psicologia da Universidade de São Paulo para obtenção do título de Mestre em Psicologia

Aprovado em:

\author{
Banca Examinadora
}

Prof. Livre-Docente Instituição:

Julgamento: Assinatura:

Profa. Dra. Instituição:

Julgamento: Assinatura:

Prof. Dr. Instituição:

Julgamento: Assinatura: 
Dedico este trabalho às pessoas empenhadas na construção e popularização de uma psicologia social latino-americana centrada na realidade histórica, social e política desta região, associada à luta contra opressões. 


\section{AGRADECIMENTOS}

Agradeço sinceramente a todas as pessoas que fizeram parte deste capítulo da minha vida, um ciclo que se completa nesta obra para dar lugar a novas aventuras.

Em especial, ao meu orientador, Alessandro de Oliveira dos Santos, pela oportunidade de colaboração, pela sua contribuição em cada etapa desse processo e pelas risadas compartilhadas na caminhada.

À minha família, minha mãe que me apoiou incondicionalmente nesta empreitada, ao meu pai e meus irmãos pela lealdade e afeto. Márcia, Vilela, Thiago e Carlinha por toda sua ajuda e carinho. Salete, Mariana, Arlete e Bruno pelas conversas, risos e caminhadas.

Às pessoas que inspiraram meu trabalho no campo psi no transcorrer de cursos, corredores e cafés, foram tantas que não caberiam aqui, agradecimentos especiais à Márcia Barreto, Vera Paiva, Fran Nascimento, Clélia Prestes, Bruno Gonçalves, Esdras Vasconcellos, Roberto Cardoso, Vinicius Melo, Gustavo Massola, Nirson Neto, Fátima, Ketiê, Sandra e Schor.

Pati, Luana, Vini, Jean Philippe, Jean Benitez, Gisele Lackeski, Mina, Diana e Marly, minhas amizades de longa data que de várias formas se fizeram presentes.

Rosângela, Nalva, Teresa e Selma agradeço por toda ajuda nesses anos e pelo carinho com que me acolheram no PST.

Minha gratidão sincera. 
Estando a caminho muitas vezes nos sentiremos em casa, outras vezes na diáspora. Em qualquer um dos casos precisaremos fazer alianças, com os outros do passado e do presente, misturar nossas vidas com as origens e tirar dali o impulso para promover hoje uma vida boa. 


\section{RESUMO}

SIQUEIRA, Gabriel Castro. Noções de bem viver latino-americanas na perspectiva da psicologia: uma revisão de escopo. 2020. 149 f. Dissertação (Mestrado em Psicologia) Instituto de Psicologia, Universidade de São Paulo, São Paulo, 2020.

Há décadas, alternativas às noções eurocêntricas de bem-estar têm sido discutidas por muitos povos na América Latina, resultando, entre outros fatores, em um conjunto de ideias agrupadas como noções de bem viver. Em linhas gerais, as noções de bem viver latinoamericanas formam um conjunto heterogêneo de ideias, em construção, que apresentam em comum propostas de bem-estar coletivo, baseadas em cosmovisões de povos indígenas deste continente, envolvendo relações comunitárias com um território. O objetivo desta pesquisa é apresentar um panorama da produção científica sobre o conhecimento relacionado às noções de bem viver latino-americanas no campo psi (Psicologia, Psicanálise, Psicologia Social). O eixo condutor é a investigação de tais noções e das possíveis contribuições deste conhecimento para o campo da Psicologia Social. Para tanto, foi realizada uma revisão de escopo, um tipo de síntese de conhecimento que segue uma abordagem sistemática para mapear evidências sobre um tópico e identificar as principais ideias, teorias e lacunas no conhecimento de determinado campo. Para seleção das obras, as bases consultadas foram: Dedalus, Google Acadêmico, Lilacs, Portal de Periódicos da CAPES, Proquest, PsycInfo, Redalyc, Scielo, Scopus, Web of Science, Youtube. De um total de 960 obras, foram selecionadas 79. Concluímos que, enquanto alternativas às noções eurocêntricas de bem-estar, as noções de bem viver apresentam: propostas de diálogo intercultural igualitário, centrados no bem-estar coletivo, em formas de produção e distribuição igualitária de recursos; em relações de equilíbrio com um território e possibilidades de transcendência do plano material. As noções de bem viver latino-americanas são propostas de sociabilidade centradas nas relações entre os seres vivos e destes com o seu espaço de vida. Portanto, discussões sobre qualidade de vida na América Latina necessitam envolver dois aspectos centrais: o conjunto de opressões e desigualdades sociais, incluindo racismo, sexismo e injustiças históricas; e a compreensão do que é uma vida desejável de acordo com os saberes, peculiaridades e modos de viver de cada povo.

Palavras-chave: Bem Viver. Psicologia Social. Qualidade de Vida. Revisão de Escopo. 


\begin{abstract}
SIQUEIRA, Gabriel Castro. A psychological perspective on Latin American notions of good living: a scoping review. 2020. 149 f. Dissertation (Master in Social Psychology) Instituto de Psicologia, Universidade de São Paulo, São Paulo, 2020.

For decades, several peoples in Latin America have been discussing alternative approaches to Eurocentric notions of well-being. In this scenario, a heterogeneous set of ideas was identified as notions of good living. In essence, Latin American notions of good living are considered a set of ideas under construction, that present in common proposals for collective well-being, based on cosmovisions of indigenous peoples of this continent, involving community relations with a territory. This research aims to present an overview of scientific production concerning Latin American notions of good living in the field of psychology (psychology, psychoanalysis, social psychology). The guiding principle is to assess the relevance of this knowledge to the field of Social Psychology. To this end, a scoping review was carried out: a type of knowledge synthesis that follows a systematic approach to map evidence on a topic and identify the main ideas, theories, and gaps in the knowledge of a given field. The sources of information consulted were: Dedalus, Google Scholar, Lilacs, CAPES Journal Portal, Proquest, PsycInfo, Redalyc, Scielo, Scopus, Web of Science, Youtube. Out of a total of 960 works, 79 met the selection criteria. We conclude that, as alternatives to the Eurocentric notions of well-being, the notions of good living present proposals centered on collective well-being, on forms of production and equal distribution of resources, on balanced relations with a territory and possibilities of transcending the material dimension. Latin American notions of good living are claims for new forms of sociability centered on the relationships between living beings and between them and their living space. Therefore, discussions of quality of life in Latin America must involve two fundamental aspects: the set of social oppressions and inequalities, including racism, sexism and historical injustices; and the understanding of what is a desirable life according to the cosmovision, peculiarities and ways of living of each people.
\end{abstract}

Keywords: Good living. Quality of life. Scoping review. Social Psychology. 



\section{SUMÁRIO}

1 APRESENTAÇÃ

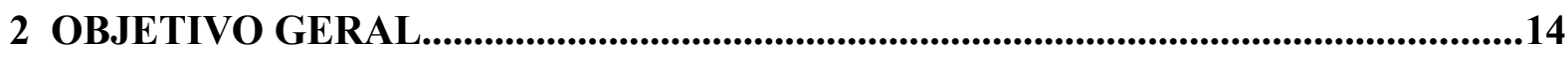

3 INTRODUÇÃ

3.1 O pensamento latinoamericanista: contexto histórico-cultural.................................20

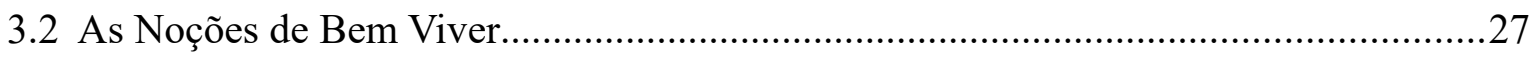

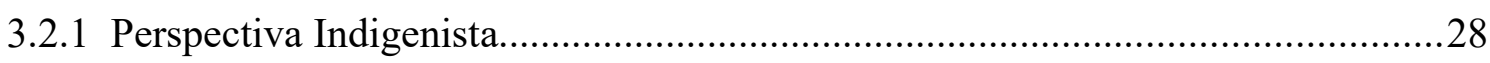

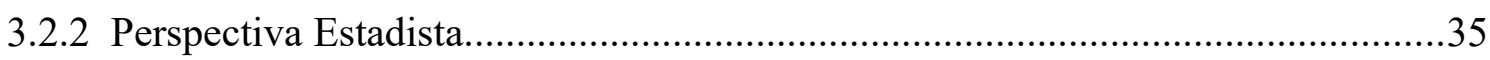

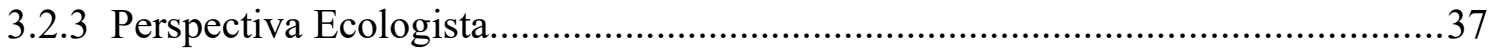

3.2.4 Aspectos comuns entre as perspectivas........................................................... 40

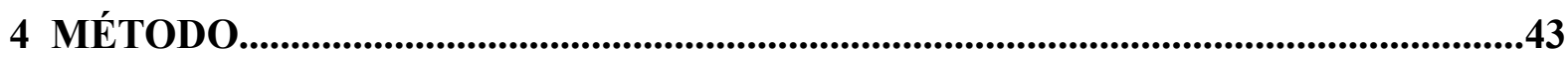

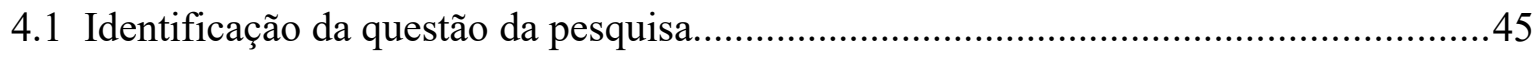

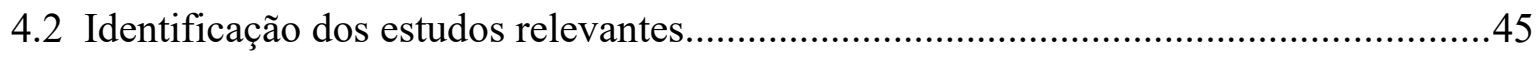

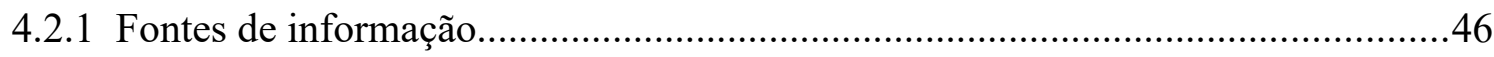

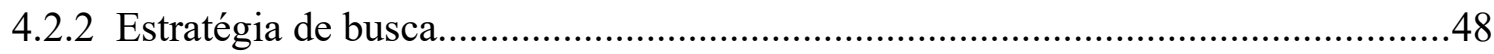

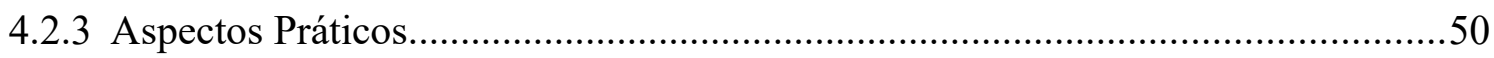

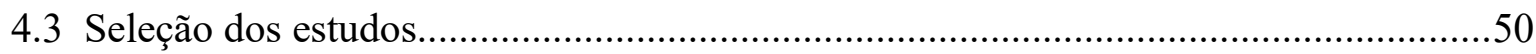

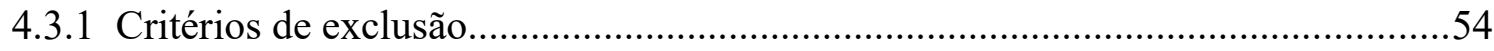

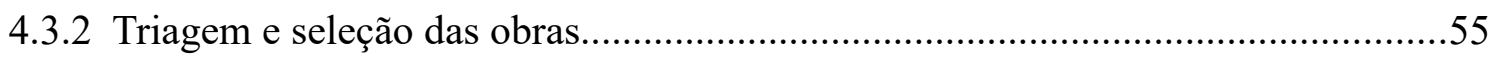

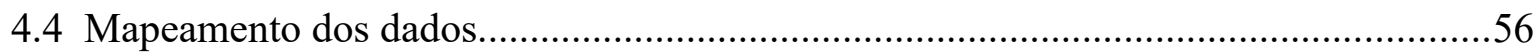

4.4.1 Teste piloto de extração de dados......................................................................57

5 AGRUPAMENTO, SÍNTESE E DISCUSSÃO DOS RESULTADOS..........................58

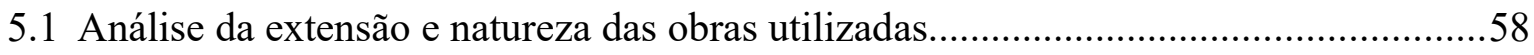

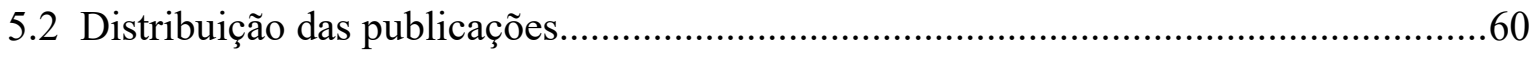

5.3 Frequência de temas relacionados às noções de bem viver.........................................63

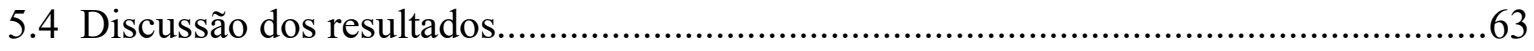

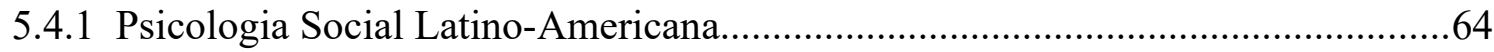

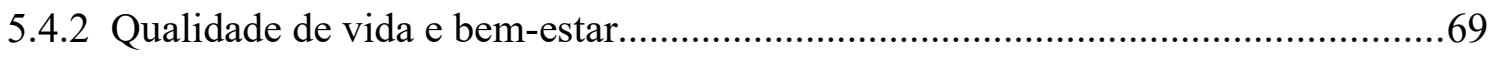

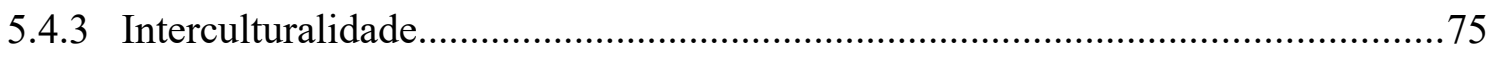

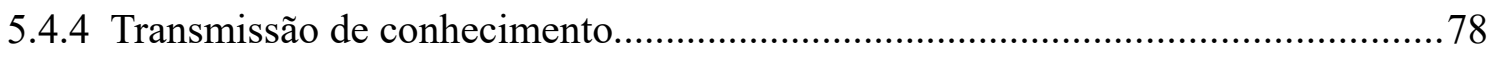




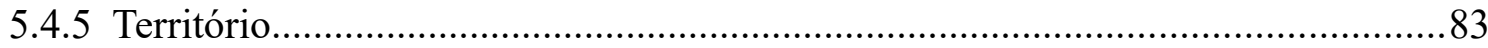

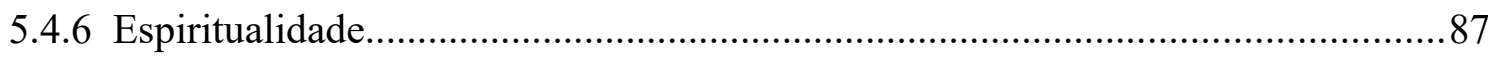

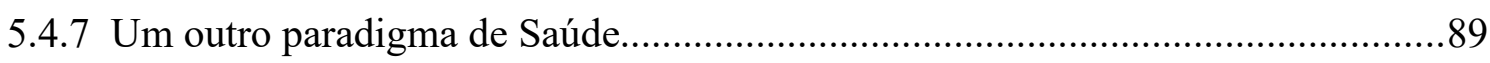

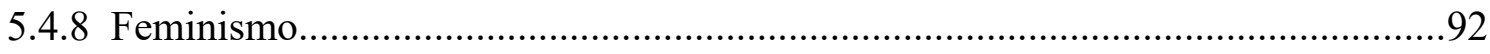

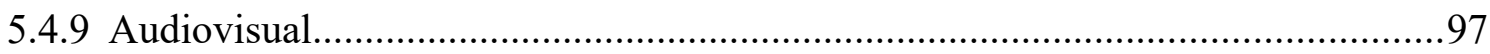

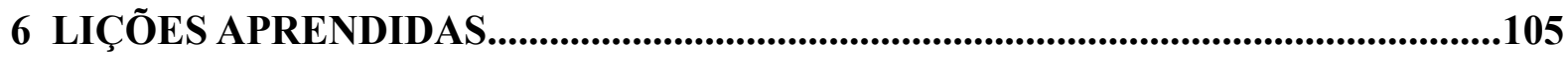

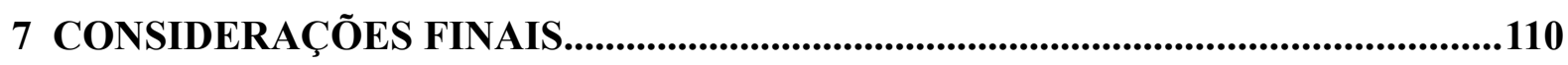

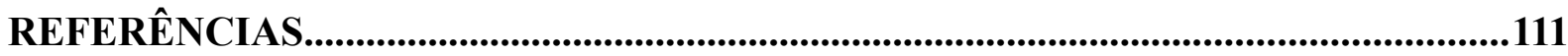

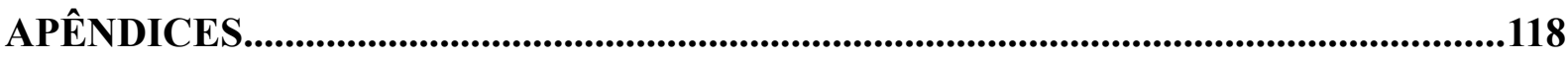

Apêndice A - Teste piloto de extração de dados................................................................118

Apêndice B - Mapeamento de dados no quadro analítico..................................................123

Anexo 1 - Guia para execução de Revisões de Escopo (PRISMA-ScR).........................149 


\section{APRESENTAÇÃO}

Por décadas eu me dediquei à busca pela felicidade. Através das experiências vivenciadas em tal busca meu objetivo foi alterado, convertendo-se no cultivo da paz interior. Talvez mesmo porque seja mais simples acreditar na possibilidade de cultivar algo que já existe dentro de si do que procurar no mundo exterior por situações, coisas ou pessoas que venham a compor um sentido de felicidade.

Em minha trajetória para cultivar essa paz interior, percebi que o bem-estar pessoal está ligado ao bem-estar coletivo, por isso meu objetivo é investigar práticas que possam melhorar a convivência entre os seres, aumentar a experiência individual e coletiva de satisfação com a vida e poder compartilhar tais práticas com o maior número de pessoas possível.

Para delimitar meu tema de pesquisa iniciei por mapear o que me parecia mais corrente segundo minha trajetória, logo, os termos felicidade e qualidade de vida surgiram. Nasci no Brasil, em 1979, em uma pequena cidade do interior do Estado de São Paulo, em uma família de origem humilde. Minha cidade se encontra em uma região onde há várias indústrias automobilísticas e de bens de consumo. Nessa região destaca-se o contraste entre vastas zonas rurais e cidades industrializadas, logo a desigualdade social extrema característica do Brasil é amplamente visível.

Devido aos meus círculos sociais mais próximos, bem como pela glorificação do capital e dos padrões eurocêntricos pela mídia de massa, minha concepção original de bemestar foi centrada no capital. Poder aquisitivo era para mim sinônimo de felicidade. Ter uma casa grande e confortável, uma segunda casa na praia, carros modernos, viagens internacionais, aparelhos eletrônicos e todo aparato fetichizado pela mídia. Todos esses itens em uma espiral de renovação e ampliação constante, numa certa perspectiva de obsolescência planejada. A lógica era simples: quanto mais bens e dinheiro, mais próximo da felicidade.

No entanto, eu começara a perceber algo errado nessa ideologia. As pessoas de meu convívio que possuíam maior poder aquisitivo não me pareciam necessariamente mais felizes. Evidentemente eu não esperava que a fórmula da felicidade fosse uma progressão aritmética, não obstante, o ciclo de consumo motivado pelo sistema capitalista não me parecia uma estratégia garantida de bem-estar interior. Comecei a duvidar do mito de que mais dinheiro é igual a mais felicidade. Nesse contexto e descontente com a crescente violência no Brasil, 
decidi imigrar para um país mais seguro, mais promissor e com menor desigualdade social.

Naquela época, ano de 2010, a economia do Canadá estava bastante aquecida, havia muitas oportunidades de crescimento profissional e a idade média da população Canadense era elevada. Lá chegando, eu logo constatei que minhas pesquisas estavam corretas quanto às condições de vida no Canadá. Em poucos meses eu comecei a acumular mais dinheiro, eu já estava bem empregado na cidade de Montreal quando comecei a notar que a vida passa muito rapidamente e que o consumismo e a acumulação de capital engendrados pelo sistema capitalista, mesmo em um país que representava para mim o padrão de sucesso desse sistema, não preenchiam o vazio da minha alma.

Mais especificamente, lembro que em 2013 duas pessoas haviam falecido no escritório onde eu trabalhava; ambas bem-sucedidas profissionalmente e com idade aproximada de 40 anos, uma por câncer, a outra devido a um infarto fulminante. Nessa época eu já fazia alguns cursos de psicologia, alguns meses depois eu decidi deixar meu emprego e me dedicar exclusivamente, no Canadá, ao estudo da Psicologia, do bem-estar e da qualidade de vida.

Estudar psicologia era um sonho de adolescente. Sonho que não foi perseguido por parecer muito distante da minha realidade socioeconômica de então e por não ter parecido na época uma boa estratégia para ganhos financeiros rápidos.

Ao estudar os mais proeminentes autores contemporâneos ocidentais, dentro da linha de estudos cognitivo-comportamentais, que se dedicam, sobretudo, à investigação do bemestar (Csikszentmihalyi, Diener, Fredrikson, Lubomirsky e Seligman) percebi que a questão da importância de nutrir boas relações pessoais é um consenso nesse campo. O fato de ser um expatriado no Canadá me excluía de um importante círculo de relações, as relações familiares.

Assim, com o passar dos anos a importância que eu atribuía a bens materiais e ao status social foi diminuindo, ao passo que a importância das relações pessoais aumentava. Portanto, em 2016, eu já estava pronto para trocar a segurança e a qualidade de vida objetiva que eu encontrara no Canadá pelos riscos de viver no Brasil e os benefícios de desfrutar dos laços familiares.

Ao buscar uma maneira de estudar qualidade de vida no Brasil, entrei em contato com pesquisadoras do Instituto de Psicologia da Universidade de São Paulo, onde encontrei o professor Alessandro de Oliveira dos Santos, que naquele momento estava co-coordenando o projeto "Mulheres Negras e Violência: A Luta por Justiça nas Américas" ao lado das professoras Vera Paiva do Instituto de Psicologia da USP, Maria Aparecida Bento do Centro 
de Estudos das Relações de Trabalho e Desigualdade (CEERT) e Christen Smith da Universidade do Texas -Austin.

Tal projeto teve inspiração em atos como a "Marcha Nacional das Mulheres Negras de 2015 Contra o Racismo, a Violência e pelo Bem Viver: O Bem Viver Como Nova Utopia”. Este movimento foi o resultado de mais de três anos de articulação de organizações da sociedade civil ligadas às mulheres negras. A "Marcha" mobilizou cerca de 50 mil pessoas em Brasília e reivindicava equidade, solidariedade e bem-estar como valores inegociáveis e que devem ser monitorados com base em indicadores tais como o bem-estar psicológico, a saúde, o uso do tempo, a educação, a cultura e o padrão de vida, segundo manifesto produzido pela Articulação de Mulheres Negras Brasileiras (AMNB) em 2015.

Assim, me engajei como pesquisador voluntário no projeto "Mulheres Negras e Violência: A Luta por Justiça nas Américas”, em paralelo ao meu percurso de estudos pessoais sobre como investigar a qualidade de vida no contexto brasileiro. Esta experiência foi de extrema importância para que eu entrasse em contato com a noção de Bem Viver.

Para melhor compreender o emprego do conceito Bem Viver nas demandas da Marcha eu conversei com Nilma Bentes, uma das idealizadoras da Marcha e liderança do movimento negro e de mulheres do Pará. Nilma esclareceu que o Bem Viver a que se referiam no manifesto da Marcha tinha raízes em movimentos políticos, inspirados em cosmovisões de povos originários da América, que já ocorriam em outros países da América do Sul, como Equador e Bolívia.

Em paralelo às minhas atividades na USP, também iniciei uma formação em psiconeuroendocrinologia na Universidade Federal de São Paulo. Esta experiência me colocou em contato com mulheres que eram encaminhadas para um serviço de atendimento psicológico de um Ambulatório de algia pélvica através do Sistema Único de Saúde (SUS). Neste contexto, pude perceber semelhanças entre concepções de bem-estar de mulheres brasileiras, residentes em São Paulo atendidas pelo SUS, e de mulheres canadenses, residentes em Montreal atendidas em clínica privada. Foi possível constatar uma certa similaridade, um padrão, sobre o que significa ter uma boa vida a despeito de realidades tão diferentes entre si.

Os temas associados ao bem-estar desses grupos orbitavam frequentemente ao redor de questões individuais: materiais, estéticas e romântico-afetivas. Fato que aumentou meu interesse em estudar concepções de bem-estar circulantes na sociedade brasileira. A reflexão crítica sobre o que determinados grupos ou pessoas consideram bem-estar requer um 
questionamento acerca das origens e mecanismos que sustentam tal concepção. Nossa proposta, portanto, é colocar em evidência as estruturas que naturalizam e perpetuam determinados padrões de bem-estar, tomados como universais.

Como a crítica à ideologia eurocêntrica e capitalista de bem-estar já habitava meu imaginário, estudar o bem viver inspirado por cosmovisões de povos originários da América Latina propiciou um caminho importante, ao possibilitar reflexões sobre o que pode ser considerado bem-estar a partir de outras perspectivas históricas e culturais. 


\section{OBJETIVO GERAL}

Levantar, sistematizar e apresentar um panorama da produção de conhecimento no campo psi acerca das noções de bem viver latino-americanas no século XXI. 


\section{INTRODUÇÃO}

Nas últimas décadas, um grande número de estudiosos do campo psi tem se debruçado sobre temas relacionados ao potencial de realização pessoal, qualidade de vida, felicidade, ou seja, noções de bem-estar. Inúmeras teorias e ferramentas têm sido desenvolvidas para aquilatar e operacionalizar categorias que possibilitem a compreensão de conceitos nesse âmbito. Contudo, é crucial questionar quais interesses, contextos e populações compõem os cenários de tais estudos.

No âmbito da "psicologia ocidental eurocêntrica" (NOGUEIRA; GUZZO, 2016, p. 206) os estudos sobre noções de bem-estar são frequentemente abordados em termos de dois paradigmas da filosofia grega: o hedonismo e a eudaimonismo.

O paradigma hedonista parte do princípio que o objetivo da existência humana é buscar prazeres e evitar desprazeres (RYAN; DECI, 2001). As primeiras conceitualizações sobre o hedonismo são comumente atribuídas a Aristipo de Cirene (435 a.C.), que defendia que o prazer era o fim supremo da vida humana, logo, as pessoas deveriam empenhar-se em buscar todas as formas de prazer possíveis e evitar a dor. Ou seja, o paradigma hedonista sugere que a busca por uma vida repleta de prazeres é um valor em si mesma.

Já o eudaimonismo coloca ênfase na atualização de potenciais humanos para se alcançar uma vida boa (RYAN; DECI, 2001). Por exemplo, para Aristóteles (335 a.C.) a finalidade tanto da vida humana quanto das ações morais era a felicidade. Na ética aristotélica a vida boa reside na virtude e na busca de um bem geral, envolvendo a intenção de uma vida boa com e para o outro, em instituições justas. Tal perspectiva coloca ênfase na reciprocidade benevolente, na solicitude, que sustenta relações harmoniosas.

Os dois paradigmas não são excludentes, e muitas linhas de estudo sobre bem-estar empregam ambos de forma complementar (TEIXEIRA FIQUER, 2006).

De acordo com Martín-Baró (1986), determinadas correntes de pensamento no campo psi são demasiadamente arraigadas no pensamento hedonista, como por exemplo a psicanálise. Segundo o autor, muito já foi discutido sobre "o hedonismo imperante na psicologia”, contudo, mesmo após décadas de críticas, a centralidade do eixo prazer e dor prevalece em muitas correntes. O pressuposto que em todo comportamento há sempre, e por princípio, uma busca de prazer ou satisfação sustenta a falácia de uma forma única de pessoa humana. Logo, permanece atual a pergunta de Martín-Baró (1986, p. 5) 
Integrar como pressuposto o hedonismo em nosso marco, não seria de fato uma concessão ao princípio de lucro fundante do sistema capitalista, e, portanto, uma transposição à natureza do ser humano daquilo que caracteriza o funcionamento de um determinado sistema socioeconômico?

Contudo, optamos por nos abster de uma discussão da filosofia eurocêntrica, pois nossa intenção é ampliar as discussões sobre conhecimentos baseados em outras cosmovisões. Nosso propósito é criar um panorama do estado da arte do conhecimento sobre noções de bem viver latino-americanas, no campo psi, independente do debate eurocêntrico entre hedonismo e eudaimonismo. Logo, nos inspiramos em outras epistemologias, as quais têm sido relegadas a uma marginalidade associada aos genocídios, e consequentes epistemicídios, que caracterizaram a invasão da América pelos europeus desde o século XV.

Epistemicídio pode ser definido como a destruição de certas formas de saber, a inferiorização de outras, o desperdício da riqueza de perspectivas presente na diversidade cultural e nas múltiplas visões do mundo por elas protagonizadas. As discussões sobre os epistemicídios que marcam o conhecimento acadêmico ocidentalizado são discutidas por Grosfoguel (2016). Sua obra corrobora para a reflexão da epistemologia fundante da psicologia tradicional enquanto ciência, bem como das ciências sociais e humanas como um todo. Uma das perguntas centrais levantadas por Grosfoguel $(2016$, p. 26) é:

Como é possível que o cânone do pensamento em todas as disciplinas das ciências sociais e humanidades nas universidades ocidentalizadas (Grosfoguel, 2012) se baseie no conhecimento produzido por uns poucos homens de cinco países da Europa Ocidental (Itália, França, Inglaterra, Alemanha e os Estados Unidos)?

Grosfoguel (2016) relaciona o racismo/sexismo epistêmico do mundo moderno ao genocídio/epistemicídio de: muçulmanos e judeus na conquista de Al-Andalus; de povos originários das Américas; de povos africanos e da escravização dos mesmos nas Américas; de mulheres europeias acusadas de bruxaria.

Martin-Baró, psicólogo social, filósofo e sacerdote jesuíta, dedicou a maior parte de sua vida à luta pelos direitos humanos, igualdade e justiça social em El Salvador, bem como à investigação da difícil realidade social e política do país. Fundador de uma psicologia social, autodenominada "psicologia da libertação", o autor afirma que as três principais causas da “miséria histórica da psicologia latino-americana" (MARTÍN-BARÓ, 1985) eram, à época: o seu mimetismo cienticista para com a psicologia norte-americana, emprestando de forma acrítica sua bagagem conceitual, metodológica e prática; a carência de uma epistemologia adequada; e o seu dogmatismo provinciano, que não se ocupava em responder às questões 
prementes da realidade latino-americana.

A carência de uma epistemologia adequada é ponto crucial em nossa discussão sobre noções de bem-estar. Alinhado com a abordagem da alfabetização conscientizadora de Paulo Freire (1970), Martín-Baró (1985) defende a importância da desideologização da experiência cotidiana, advertindo fortemente sobre o papel dos meios de comunicação de massa na divulgação de um discurso hegemônico de ideal de vida que não se encaixa na realidade das maiorias populares da América Latina.

Tratando-se de uma ciência que busca promover equilíbrio e saúde, é um dever da psicologia questionar tais ideologias, de modo a auxiliar na reflexão das camadas populares sobre a compreensão de suas realidades e na realização de seus potenciais.

Pesquisar o tema do bem viver visa trazer para o centro dos debates no campo da psicologia saberes que têm sido sistematicamente marginalizados, objetivando amparar a reflexão crítica sobre o que tem sido imposto como bem-estar pelo sistema capitalista, incluindo as formas altamente individualistas e individualizantes das abordagens hedonísticas/ adaptacionistas da psicologia ocidental eurocêntrica.

Nosso debate envolve portanto o que Paulo Freire (1980) definiu como conscientização, o processo de transformação pessoal e social que experimentam os oprimidos da América Latina ao se alfabetizarem em dialética com seu contexto; onde alfabetizar-se significa, sobretudo, aprender a ler a realidade circundante e a escrever a própria história. Martín-Baró afirmou que a conscientização é o "horizonte primordial do quefazer psicológico" (1985). Através da capacidade de nos distanciarmos frente ao mundo para objetivá-lo, podemos desenvolver percepções mais nítidas da realidade, incluindo os mecanismos que naturalizam processos de individualização e opressão. A conscientização é composta de processos que permitem transcender a esfera espontânea de apreensão da realidade para uma esfera crítica, sobre a qual se assume uma posição epistemológica (GUZZO, 2014).

Portanto, propomos aqui uma reflexão aos profissionais da psicologia face aos conceitos eurocêntricos de bem-estar. De acordo com Martín-Baró a conscientização consiste de três aspectos centrais: processos dialéticos, ativos, de transformar-se através da modificação das relações com o seu ambiente e acima de tudo com as outras pessoas; decodificação do contexto, de quaisquer mecanismos de opressão e desumanização; e descobrir-se como pessoa histórica, descobrir as raízes do que se é e o horizonte do que se 
pode chegar a ser, do potencial de realização, pois “a recuperação da memória histórica oferece a base para uma determinação mais autônoma do próprio futuro" (p.61, 1985).

A reflexão crítica sobre a realidade é atividade necessária no quefazer da psicologia, como processo gradual em que a pessoa, na medida em que conhece e age no mundo, transforma-o e transforma a si mesma, sendo agente de sua própria história (GUZZO, 2014). É válido ponderar que a conscientização articula possibilidades de transformação social a partir da esfera individual. Contudo, salientamos que a conscientização pode ser discutida em termos de gerar cidadania, de se pensar o ser como parte do todo, pois todo comportamento envolve uma dimensão social, constituída por fatores sociais onde se materializa a individualidade humana.

Para facilitar nossa discussão a respeito de uma reflexão crítica sobre a realidade, empregamos a noção de colonialidade do poder, cunhada pelo sociólogo peruano Aníbal Quijano. Tal noção nos orienta na análise de nossa conjuntura atual, bem como do projeto civilizatório que inaugurou e sustenta até hoje a propagação global de modelos e padrões eurocêntricos de ser, de relações, de saberes e da produção de conhecimentos.

A colonialidade do poder (QUIJANO, 2000) é um padrão de poder que emergiu como resultado da invasão da América pelos europeus, especialmente espanhóis e portugueses, a partir do século XVI, e se refere a forma como o trabalho, o sexo, a autoridade pública e a subjetividade/intersubjetividade se articulam entre si através do mercado capitalista mundial e da diferença colonial imposta entre povos conquistadores e conquistados. Portanto, o conceito aponta a continuidade das formas coloniais de dominação, séculos após o fim das administrações coloniais, perpetuadas pelas culturas coloniais e pelas estruturas do sistemamundo capitalista moderno (GROSFOGUEL, 2016).

De acordo com Quijano (2000), o poder é considerado uma relação social que articula permanentemente três elementos: dominação, exploração e conflito, e afeta as quatro áreas básicas da existência social: 1) trabalho, seus recursos e seus produtos; 2) sexo, seus recursos e seus produtos; 3) a autoridade coletiva (ou pública), seus recursos e seus produtos; 4) subjetividade / intersubjetividade, seus recursos e seus produtos. Essas áreas da vida social operam de forma dependente, porque não podem existir uma sem a outra, formando um sistema dinâmico complexo, cujo caráter é sempre histórico e específico, constituindo um padrão histórico de poder.

Dois eixos fundamentais determinam a colonialidade do poder, dois processos 
históricos que convergiram e se associaram: a codificação de diferenças entre conquistadores e conquistados na ideia moderna de raça, ou seja, em supostas diferenças biológicas que situavam certos grupos como naturalmente inferiores a outros; e a "articulação de todas as formas históricas de controle do trabalho, de seus recursos e produtos, em torno do capital e do mercado mundial" (QUIJANO, 2000, p. 227).

Tomando em conta a violência com que os europeus invadiram a América, notadamente os genocídios e escravizações, todas as experiências, histórias, produtos culturais, saberes e formas de produção de conhecimento terminaram também subjugados a uma única ordem cultural global em torno da hegemonia europeia (ou ocidental), ao que podemos chamar de colonialidade do saber (SEGATO, 2014).

O tipo de capitalismo que se desenvolve a partir da invasão da América criou formas de controle da subjetividade, da cultura e da produção de conhecimento. Portanto ocorreu a colonização das perspectivas cognitivas, dos modos de produzir e outorgar sentido aos resultados das experiências materiais ou subjetivas, do imaginário, do universo das relações intersubjetivas. De acordo com o caderno "Referências técnicas para atuação de psicólogas(os) com povos tradicionais” do Conselho Federal de Psicologia (2019, p. 57)

\begin{abstract}
A modernidade teve seu alicerce nos processos de colonização e estende seu projeto de sociedade até os dias atuais por meio da colonialidade do poder que envolve aspectos: políticos, epistêmicos, estéticos e ontológicos. E este projeto de sociedade tem nas categorias étnico-racial, gênero, domínio da natureza, controle do trabalho e hegemonia epistêmica suas bases para diferenciação e hierarquização da humanidade dos povos colonizados frente aos brancos europeus.
\end{abstract}

A noção de colonialidade do poder é uma perspectiva teórica que além de reconfigurar o discurso histórico das relações da América na estrutura de poder mundial imprime um novo rumo a leitura da história mundial. Não é uma teoria para e sobre a América Latina, ela se refere ao conjunto de poder globalmente hegemônico (SEGATO, 2014).

Logo, para alterar perspectivas cognitivas colonizadas é necessária uma "subversão latino-americana a respeito do modo eurocêntrico de produção de intersubjetividade" (QUIJANO, 2014, p. 11). Destarte, nossa proposta se alinha aos ideais dos autores decoloniais, na produção de perspectivas epistêmicas, teóricas, históricas, estéticas e políticas opostas e alternativas ao eurocentrismo. De acordo com Quijano (2014), as noções de bem viver inspiradas nas cosmovisões dos povos originários da América Latina, com sua extraordinária heterogeneidade histórica, representam um horizonte histórico de sentido alternativo ao eurocêntrico. 
Nesta obra, investigamos produções, pensamentos e teorias que reflitam modos de existir em diálogos interculturais, unindo-nos ao movimento de estudos para a descolonização do campo psi. Nossos esforços estão, portanto, alinhados com movimentos que prezam pelo desenvolvimento de uma ciência baseada nas realidades latino-americanas, concebidas em função das necessidades de nossas sociedades, assim como tem sido evidenciado nas bases da psicologia social comunitária, da psicologia social crítica e da psicologia da libertação (MONTERO, 1994).

Nessa perspectiva, levantamos questões sobre o significado de viver bem na América Latina; estariam as noções de bem viver dos povos indígenas em alguma forma relacionadas aos conceitos de vida feliz do Norte Global? Considerando-se a realidade social e política latino-americana, poderia o campo da Psicologia se beneficiar ao introduzir acepções de qualidade de vida oriundas de noções indígenas a outros grupos? Motivados por esse tipo de perguntas, nos debruçamos sobre a investigação do que tem sido produzido sobre as noções de bem viver no campo psi.

\subsection{O pensamento latinoamericanista: contexto histórico-cultural}

Assim como são heterogêneos os povos que compõem a América Latina, também são múltiplas as noções de bem viver. Neste capítulo discorremos sobre as origens e principais semelhanças entre as noções de bem viver presentes no continente.

No presente texto, adotamos o termo indígena para nos referirmos aos povos que já habitavam a América Latina antes da invasão europeia iniciada no século XV. Empregamos também o termo indígena com o significado de pessoa ou ideia nativa. $\mathrm{O}$ termo provém do latim, "indigěna, ae, natural do lugar em que vive, gerado dentro da terra que lhe é própria" (AULETE, 1980). Evidentemente, todos os termos que sociedades coloniais impõem aos povos originários de uma região são atribuições exógenas e nos expõem ao risco de transmitir uma ideia errônea de homogeneidade, ou risco de romantização de um universo indígena. A partir do século XVI, uma série de termos foram empregados para designar a totalidade dos povos originários, esse mecanismo colonial impunha uma suposta homogeneidade propícia para a opressão, exploração e genocídio desses povos.

O termo indígena, em âmbito político e legal, é adotado pela Fundação Nacional do Índio (FUNAI), é também um termo amplamente utilizado por intelectuais indígenas (BANIWA, 2006; NAIÍNE TERENA, 2014), de acordo com o intelectual indígena Gersem 
Baniwa (2006, p. 30)

Com o surgimento do movimento indígena organizado a partir da década de 1970, os povos indígenas do Brasil chegaram à conclusão de que era importante manter, aceitar e promover a denominação genérica de índio ou indígena, como uma identidade que une, articula, visibiliza e fortalece todos os povos originários do atual território brasileiro e, principalmente, para demarcar a fronteira étnica e identitária entre eles, enquanto habitantes nativos e originários dessas terras, e aqueles com procedência de outros continentes, como os europeus, os africanos e os asiáticos.

Salientamos que buscamos nesta pesquisa manter um estado de alerta constante para enfatizar a imensa heterogeneidade dos povos originários da América do Sul, a diversidade de seus modos de organização, de expressão de seus saberes e formas de existir. Destarte, considerando os limites de nosso idioma, de nossa perspectiva cognitiva, da plataforma de registro e dos meios de comunicação utilizados para o presente trabalho, empregaremos os termos povos indígenas ou povos originários, pela perspectiva supracitada.

Essas noções representam, sobretudo, utopias de um mundo melhor, de um projeto civilizatório que garanta a sobrevivência da espécie humana e de todos os outros seres (DUSSEL, 2018), um projeto que possa substituir o projeto civilizatório capitalista/moderno. Nesse contexto, uma utopia social é uma nova ordem possível, uma ordem mais justa que a ordem presente. Uma nova ordem possível não pressupõe uma estratégia precisa, ela necessita, sobretudo, de critérios e princípios para alcançar um novo sistema (DUSSEL, 2018).

De acordo com o CFP (2019), as origens das utopias latino-americanas encontram-se logo no início da invasão europeia, presentes em diversos grupos que de maneiras distintas vislumbravam a possibilidade de um Novo Mundo, de uma "terra sem males", um paraíso em terra. Desde as descrições dos primeiros europeus.

Dentre estes grupos, destaca-se a atuação das missões jesuíticas junto aos povos originários na região sul do continente. O pensamento utópico latino-americano também esteve presente na vida de líderes políticos e idealizadores de uma América unida em torno dos mesmos valores.

Quijano (2014) aponta que os primeiros registros em língua europeia de uma noção de bem viver inspirada em saberes e práticas de povos originários da América Latina foram reivindicadas no âmbito da administração colonial do Vice-Reino do Peru, articuladas em obra que clamava por uma ordem social mais justa, por Felipe Guaman Poma de Ayala, 
cronista e intelectual de origem Inca, no início do século XVII. De acordo com Quijano (2014, p. 87):

Bien vivir es, probablemente, la formulación más antigua en la resistencia indígena contra la colonialidad del poder. Fue, notablemente, acuñada en el Virreinato del Perú, por nada menos que Guaman Poma de Ayala, aproximadamente em 1615, en su Nueva corónica y buen gobierno.

A crônica de Guaman Poma, escrita parte em espanhol e parte em quéchua, reivindicava mudanças governamentais e apontava a forma violenta de exploração dos povos originários pela administração colonial do vice-reino do Peru junto ao rei Felipe III de Espanha. Sua obra é escrita a partir do lado marginalizado da modernidade, de uma compreensão de mundo advinda da "periferia" e da carência, formada através de vivências com povos originários em grande parte do território peruano, ou seja, da grande maioria oprimida (ORTIZ FERNANDES, 2014).

Em sua obra, além de usar o termo "bien vivir" como sinônimo para bom governo, Guaman efetua o primeiro registro do termo "sapci", que pode ser compreendido como "aquilo de propriedade e uso comum a todos" (ORTIZ FERNANDES, 2014). O termo que tem centralidade na obra está amplamente associado à ideia de bom governo, como eixo central de um projeto de restituição da justiça e igualdade para os povos indígenas. A centralidade do termo realça o tom distinto do discurso da obra, o qual exige a garantia do acesso à terra e aos meios de subsistência para todos seus habitantes.

Essa obra de Guaman Poma (1615) projetava elementos de sua formação cristã, em repetidos trechos ele sugeria que sua crônica poderia servir como instrumento "proveitoso para os fiéis cristãos para emenda de seus pecados" (p. 17), e sua proposta de educação intercultural dos desprovidos incluía o ensino e prática da virtude sustentada na fé cristã. Salientamos que a obra foi escrita diretamente para o rei de Espanha, assim "quando escreve em castelhano (como o faz na maior parte de seu manuscrito de 1000 páginas) seu ego colonial vigilante fala por ele... para assegurar-se de que o rei de Espanha o considerasse um de seus súditos mais fiéis" (CUSICANQUI, 2011, p. 175). Por outro lado, as centenas de ilustrações que criou para essa obra exprimem a crueldade predominante na ordem social, vital e cósmica de seu entorno.

Portanto, suas propostas sociais e políticas, apresentadas em uma escrita repleta de mística, religiosidade e influências cristãs, delineavam os contornos de uma utopia ética e estética que espalhou-se no imaginário social até manifestarem-se nos diversos movimentos 
indígenas, entre eles a emblemática revolução de Túpac Amaru (1780).

Em Simón Bolívar (1783-1830) encontramos outro expoente das utopias latinoamericanas e um pioneiro do pensamento latino-americano continental. Ele foi um líder político e militar venezuelano, chefe das revoluções que libertaram a Venezuela, Colômbia, Equador, Panamá, Peru e Bolívia do domínio espanhol. Bolívar defendia a ideia utópica de uma América Latina unificada em uma grande federação de nações soberanas. Embora fosse um antimonarquista convicto também haviam contradições e ambiguidades em seus ideais, como sua proposta de um senado hereditário como base fundamental do poder legislativo ou a centralização do poder para a união política da América Latina. Por outro lado, em sua luta anticolonial, destacam-se alguns aspectos progressistas para a época, como a abolição da escravidão e a busca por instituições políticas e culturais adequadas às especificidades do continente.

Outra visão utópica de caráter continental para a América Latina é encontrada na obra e vida de José Martí (1853-1895), pensador e herói da independência cubana. Martí defendia a formação utópica de uma união continental formada pelas nações constituintes da América Latina, denominada "Nuestra América". No centro de seu ideal político e humanista está a autoctonia, apresentada como formas políticas, econômicas e culturais próprias a especificidade histórica de "Nuestra América". Martí propõe um projeto civilizatório alternativo ao capitalismo, amparado em dois pilares: a valorização da cultura autóctone e a superação da dualidade na relação humanidade versus natureza, uma crítica profunda à visão de humanidade produzida pelo padrão civilizatório ocidental.

Em sua perspectiva a natureza não é vista como matéria-prima a ser explorada pelas forças produtivas, contrariamente, é na relação com a natureza que a humanidade encontra seu potencial de transcendência. Não somente a espiritualidade, mas também os sentimentos emergem como dimensões essenciais na produção e expressão do conhecimento. Assim, Martí sugere formas alternativas de percepção da realidade e da construção do conhecimento, que partem de uma lógica que inclui os sentimentos e a transcendência da matéria. Seu pensamento vinculava o potencial de transcendência, ou seja, de realização espiritual, a uma resposta política a problemas históricos.

A partir desse pensamento sobre a transcendência apresentamos outra vertente das utopias latino-americanas, a religiosidade messiânica. As grandes experiências messiânicas no Brasil, como, por exemplo, a revolta de Canudos e do Contestado, contaram com uma 
liderança carismática e profética na busca de um novo mundo utópico, de uma terra sem males, onde todos pudessem viver em condições de igualdade (CFP, 2019).

No final do século XIX, o povoado de Canudos no sertão baiano, teve como fundador e líder religioso Antônio Conselheiro, que pregava uma mistura de doutrina cristã e religiosidade popular em um povoado autônomo, organizado em torno do trabalho coletivo, da distribuição igualitária da produção, da devoção e da oração, em um cenário de condições extremas de seca e pobreza. Acredita-se que muitos sertanejos seguiram ao Conselheiro embalados pela crença no discurso da salvação da alma e da busca do paraíso cristão.

Na região de Contestado (Santa Catarina), o acúmulo de problemas sociais culminou em um conflito armado, entre 1912 e 1916, onde pereceram por volta de 9000 pessoas. Para a maioria dos rebeldes, o conflito significou a concretização de antigas expectativas em torno de profecias, há muito, difundidas por religiosos. O líder religioso José Maria, que se opunha ao autoritarismo da ordem republicana, pregava novos tempos de prosperidade e comunhão espiritual e profetizava revoltas que colocariam fim à fome e à miséria. A revolta de Contestado tratava-se, segundo a crença de seus seguidores, da profetizada "Guerra de São Sebastião" (SALOMÃO, 2009, p. 10).

Esses representantes emblemáticos da história latino-americana tinham em comum em suas obras e práticas elementos espirituais na composição de utopias que delineavam modos de conviver de forma mais igualitária, contra opressões de qualquer cunho. Ilustram a importância de considerar o papel da espiritualidade, da religião, da devoção na América Latina.. Desde a invasão da América, o contato entre as culturas propiciou interpretações das mais variadas na esfera místico religiosa, seja pela imposição da fé católica, receptividade de alguns povos originários para outras místicas ou a transformação das espiritualidades indígenas, resultantes do contato violento entre povos tão distintos.

Também a Revolução Cubana (1953 - 1959) tem impacto profundo na formação do pensamento latino-americano, os desdobramentos e a efervescência da produção literária pósrevolução influenciam a convergência entre a questão identitária latino-americana e a luta social no continente, propiciando discussões que resultam na categoria filosófica da Libertação (SIMÕES GONÇALVES, 2014).

De acordo com Simões Gonçalves (2014) o debate entre o peruano Augusto Salazar Bondy e o mexicano Leopold Zea é um dos marcos fundamentais da Filosofia da Libertação, Considerando o potencial de uma filosofia latino-americana que seja própria (BONDY, 1968) 
e auntêntica (ZEA, 1968), esses dois filósofos se questionaram mutualmente criando a base de pensamento de uma filosofia da libertação. Ambos filósofos concordavam que o florescer de uma filosofia latino-americana exigia que se levasse em consideração os problemas históricoconcretos específicos da América Latina e os caminhos de sua superação. Além da filosofia, outras ciências também incorporaram os marcos da categoria filosófica da Libertação, como, por exemplo, a pedagogia, a teologia, a sociologia e a psicologia.

Nos anos sessenta começa a tomar forma a Teologia da Libertação, uma corrente de pensamento teológico cristã, caracterizada pela “opção preferencial pelos pobres” e que utiliza as ciências humanas e sociais para pensar a realidade social e histórica das populações em situação de pobreza rumo à sua libertação contra as opressões. Prima por uma análise profunda do significado da pobreza, dos processos históricos de empobrecimento e se compromete com os processos de liberação dos oprimidos. Uma abordagem que considera a pessoa no tecido das relações sociais, em suas coordenadas econômico-sociais, culturais e étnico-raciais (GUTIERREZ, 1972/2000). A noção cristã sobre “ajudar ao próximo” é ampliada para o pensamento de ajudar a massa pobre e oprimida a se liberar de condições de vida intoleráveis e tomar em mãos seu destino, pela construção de um "reino de deus" que já começa na terra.

De acordo com Lowy (1991), a despeito das divergências entre os teólogos da libertação, há temas fundamentais que aparecem repetidamente nas mais diversas obras, os quais revelam uma saída radical da doutrina tradicional das igrejas católicas e protestantes. Dentre os consensos apontados por Lowy (1991), estão: a opção preferencial a favor dos pobres e da solidariedade para com sua luta de emancipação social; acusação moral e social contra o capitalismo como sistema injusto e cruel, uma forma de pecado estrutural; o uso de instrumentos marxistas para análise das causas da pobreza, das contradições do capitalismo e das formas de luta de classes; a criação de comunidades cristãs de base entre os pobres como alternativa ao modo de vida individualista imposto pelo sistema capitalista e a luta contra a idolatria ao consumismo, a riqueza, ao poder, ao Estado, aos exércitos.

Notadamente, alguns dos consensos apontados por Lowy (1991) são similares aos que encontramos em noções de bem viver. Autores expoentes da Teologia da Libertação já escreveram sobre o bem viver, por exemplo, Leonardo Boff (2009), François Houtart (2011) e Fernando Vega (2012).

A Teologia da Libertação enquanto movimento científico religioso contemporâneo 
atualiza a tradição utópica latino-americana "através do diálogo entre diferentes tradições cristãs e não cristãs com o pensamento utópico de tradição marxista" (CFP, 2019), notadamente em suas lutas contra a opressão e pela libertação dos povos. Sendo, portanto, um movimento que também revaloriza as formas de vida das populações indígenas.

A Psicologia da Libertação, elaborada por Ignácio Martín Baró nos anos 80, nasce especialmente voltada à vida das maiorias pobres e oprimidas na América Latina, representando um compromisso ético e político com as populações mais carentes do continente. A Psicologia da Libertação prima, sobretudo, pela reconstrução teórica e prática da psicologia, tendo como eixo central a vida das maiorias oprimidas, de seu sofrimento, suas aspirações, seus dilemas. O esforço em desenvolver uma psicologia para a América Latina, para além de um esforço teórico, concentra-se na prática, na criação de serviços que atendam às necessidades da maioria pobre da população (GUZZO, 2014).

Apresentando uma crítica profunda à ideia de universalidade sustentada pela psicologia social tradicional (norte-americana, europeia), Martín-Baró (1986) elabora uma psicologia social centrada em fomentar o protagonismo das pessoas oprimidas nos processos de transformação social, para superar imposições de subalternidade, na luta contra desigualdades sociais.

Uma das principais ferramentas defendidas pelo psicólogo salvadorenho é a conscientização (ou desideologização) enquanto processo de retomada da trajetória de vida individual e coletiva a partir do fortalecimento das memórias históricas. O processo de conscientização é possível através da recuperação e ressignificação da memória histórica da população oprimida. A recuperação da memória histórica tem amplo significado em sua obra (Martín-Baró, 1986, p. 10)

Se trata de recuperar no sólo el sentido de la propia identidad, no sólo el orgullo de pertencer a un pueblo así como de contar con una tradición y una cultura, sino, sobre todo, de rescatar aquellos aspectos que sirvieron ayer y que servirán hoy para la liberación. Por eso, la recuperación de una memoria histórica va asuponer la reconstrucción de unos modelos de identificación que, en lugar de encadenar y enajenar a los pueblos, les abra el horizonte hacia su liberación y realización.

Nesse contexto, a prática do psicólogo social junto às populações oprimidas deve ser baseada em ações de caráter político e emancipador. $\mathrm{O}$ marco da categoria filosófica da Libertação inspira movimentos intelectuais de grande potencial para a matriz epistêmicopolítica latino-americana, para além da filosofia, da teologia e da psicologia da libertação, se 
desenvolveram a educação libertadora de Paulo Freire e a sociologia da Libertação de Orlando Fals Borda.

Portanto, as utopias latino-americanas (embebidas de religiosidade e misticismo), incluindo a construção de um pensamento latino-americano continental e a categoria filosófica da Libertação (e todos seus desdobramentos), conjunto que doravante chamaremos de pensamento latinoamericanista, representam um dos eixos centrais do cenário que antecede e alimenta as discussões filosóficas, sociais, econômicas e políticas presentes nos movimentos indígenas e campesinos, notadamente do Equador e da Bolívia, os berços da popularização das noções de bem viver.

\subsection{As Noções de Bem Viver}

Após uma década de extensa pesquisa sobre o tema, Ana Patricia Cubillo-Guevara e Luiz Antonio Hidalgo-Capitán da Universidade de Huelva, na Espanha, têm publicado obras sobre a genealogia das noções de bem viver $(2012 ; 2015 ; 2017 ; 2019)$, os autores apontam que seria próximo a um consenso afirmar que noções de bem viver, em geral, são formas de viver em equilíbrio: consigo (identidade), com a sociedade (equidade) e com a natureza (sustentabilidade). Contudo, toda tentativa de especificar o que é "viver em equilíbrio" emerge associada a "mananciais de conhecimento" que apresentam significados distintos, de acordo com a posição ideológica de cada pessoa, seja ela intelectual, política ou militante.

A partir dessa perspectiva, os autores afirmam que há ao menos três maneiras de se entender o bem viver a partir de arcabouços epistemológicos distintos: a indigenista, a socialista/estadista e uma terceira, ecologista e pós-desenvolvimentista (CUBILLOGUEVARA; HIDALGO-CAPITÁN, 2012).

A abordagem de análise do bem viver a partir de três eixos principais é corroborada no livro dos pesquisadores Matthieu Le Quang e Tamia Vercoutère, "Ecosocialismo y Buen Vivir: Diálogo entre dos alternativas al capitalismo" (2013). A discussão dos autores gira em torno da análise de três correntes de pensamento que fundamentam as noções de bem viver: a corrente culturalista, como discurso de povos indígenas da América Latina; a corrente ecomarxista; e a corrente ecologista.

A partir de nossas próprias investigações, consideramos que a discussão em três eixos é profícua para apresentar ideias sobre os empregos e a propagação das noções de bem viver. Contudo, conforme discutimos no capítulo anterior, o pensamento latinoamericanista 
representa um eixo central que antecede e propicia a formação do movimento do bem viver, além de significar um importante horizonte teórico e prático que continua a orientar militantes, acadêmicos e políticos. Uma vez que já comentamos o pensamento latinoamericanista, discutiremos na sequência a perspectiva indigenista, da qual emergem os primeiros usos das noções em movimentos sociais. Em seguida discutiremos a perspectiva socialista e estadista, a qual originou-se através da chegada ao poder do Movimiento al Socialismo (MAS) de Evo Morales na Bolívia e de Alianza PAIS (Patria Altiva y Soberana) de Rafael Correa no Equador, e, particularmente, através da aprovação das Constituições de ambos países. Finalmente, abordaremos a perspectiva ecologista, baseada na ecologia profunda, com forte influência das teorias pós-desenvolvimentistas e do biocentrismo, uma concepção de mundo onde a natureza é a medida para todas as coisas e possui valor intrínseco e, portanto, deve ter seus direitos reconhecidos.

\subsubsection{Perspectiva Indigenista}

Os primeiros registros de uma noção latino-americana de bem viver como horizonte ético e político são atribuídos a intelectuais indígenas da Amazônia equatoriana (CUBILLOGUEVARA; HIDALGO-CAPITÁN, 2015), em associação com a Organización de los Pueblos Indígenas del Pastaza (OPIP), para intermediar negociações de recursos financeiros com organizações não governamentais europeias, no início dos anos noventa (MARTINEZNOVO, 2018; CUBILLO-GUEVARA, 2016; VITERI, 2003).

Uma noção de sumak kawsay emerge nesse cenário como uma alternativa ao conceito de desenvolvimento sustentável que até então era utilizado pela OPIP, refletindo uma concepção sobre um modo de viver desejável para a comunidade Quíchua de Sarayaku (na Amazônia Equatoriana), em contraste com a concepção ocidental de desenvolvimento sustentável. Este modo desejável de viver, expressado como vida harmônica, foi então apresentado como sumak kawsay (buen vivir) e registrado no Plano Amazanga da OPIP em 1992, o qual tinha como principal demanda a legalização de territórios para comunidades indígenas de Sarayaku (VITERI, 2003).

Essa alternativa ao conceito de desenvolvimento que surgiu em 1992, contou com o apoio da ONG italiana Terra Nuova e da ONG dinamarquesa IBIS para o desenvolvimento do Plano Amazanga. O antropólogo quíchua amazônico Carlos Viteri (2003) afirma que propôs em 1992 o sumak kawsay (viver em abundância, sabedoria e dignidade) como um novo 
paradigma para que se possa alcançar uma boa vida, uma convivência equilibrada entre povos e culturas, e desses com a mãe natureza, diante do fracasso global da ideologia do desenvolvimento.

Viteri (2003) sistematizou em sua tese de licenciatura uma noção de bem viver, enquanto prática social, baseada em pesquisa sobre seu povo na região de Sarayaku na Amazônia equatoriana. Em suma, a noção emerge de um exercício coletivo de reflexão (com diversos membros da comunidade) a partir de suas visões (crenças e mitos) de uma existência desejável em contraste aos conceitos ocidentais de desenvolvimento sustentável. A família Viteri teve e tem grande influência no movimento indígena equatoriano, tendo participado da criação e liderança da OPIP nos anos noventa. De acordo com Carlos Viteri (2003, p. 43), sumak kawsay reflete:

Una visión holística a cerca de lo que debe ser el objetivo o la misión de todo esfuerzo humano, que consiste en buscar y crear las condiciones materiales y espirituales para construir y mantener el 'buen vivir'; que se define también como 'vida armónica', que en idiomas como el runa shimi (qichwa) se define como el alli káusai o súmac káusai. Súmak káusai es 'buen vivir' o 'vida armónica' (...) aquello que los sarayakuruna conciben como el sentido ideal de la vida. Es un concepto formado por dos palabras: súmak que significa lo bueno, lo bello, lo armónico, lo perfecto, lo ideal y káusai que significa vida, existencia. Esta expresión (...) alude a una condición ideal de existencia sin carencias o crisis (...) y a una práctica social orientada para evitar caer justamente en condiciones aberrantes de existencia.

Ainda segundo Viteri (2003), enquanto proposta holística, o sumak kawsay compreende a diversidade de elementos a que estão condicionadas as ações humanas que propiciam o bem viver: o conhecimento, os códigos de conduta ética e espiritual em relação ao entorno, os valores humanos, a visão de futuro.

Essa noção de bem viver (como tradução de sumak kawsay) foi adotada pelo Banco Interamericano de Desenvolvimento (BID) no início de 2004, quando Carlos Viteri, era funcionário de tal organização (MARTÍNEZ-NOVO, 2018). O surgimento do sumak kawsay, e especialmente sua subsequente sistematização, foi claramente influenciada por antropólogos estrangeiros e nativos que trabalharam na Amazônia equatoriana durante as décadas de 80 e 90 do século XX, como Philippe Descola (1986), Elke Mader (1999) e Carlos Viteri (2000), que introduziram neste território a noção de pós-desenvolvimento (CUBILLO-GUEVARA, 2016). 
Esses intelectuais começaram a desenvolver um discurso local de transformação social para alcançar um futuro baseado no cotidiano dos povos originários, em seu passado e em sua cosmovisão, articuladas como uma forma desejável de viver, sumak kawsay, vida em equilíbrio ou boa vida.

Dessa forma, a elaboração do discurso inicial de sumak kawsay baseava-se nas cosmovisões dos povos da Amazônia, no seu rompimento com a ideia de desenvolvimento da modernidade ocidental. Apresentava-se como um quadro de referência cultural para a alternativa não moderna ao desenvolvimento.

A partir dos anos 2000, Alberto Acosta, que, à época, era membro do Movimiento de Unidad Plurinacional Pachakutik - Nuevo País (MUPP-NP) e acadêmico do Instituto Latinoamericano de Investigaciones Sociales (ILDIS), passou a divulgar o tema nos termos apresentados por Viteri $(1992 ; 2000)$. Anos mais tarde, Acosta participou da fundação do Movimento da Aliança PAIS, em 2006, incluindo na proposta governamental do partido a noção de bem viver, inspirada no sumak kawsay quíchua amazônico, como uma "alternativa ao desenvolvimento", que deveria ser construída de maneira participativa. Foi ministro de Energia e Minas no primeiro governo de Rafael Correa em 2007, Presidente da Assembleia Constituinte do Equador entre 2007 e 2008 e membro da comissão sobre o regime econômico (Mesa 7) que incluiu o sumak kawsay na Constituição da República do Equador de 2008. Depois de deixar a Presidência da Assembleia Constituinte do Equador, tornou-se o principal divulgador acadêmico nacional e internacional de uma noção de bem viver de caráter pósdesenvolvimentista.

Outra passagem transformadora na história dessas noções é a divulgação da noção amazônica quíchua equatoriana no mundo andino. O discurso inicial do sumak kawsay amazônico foi rapidamente assimilado pelos intelectuais do mundo andino equatoriano, do Peru e da Bolívia (Quíchua e Aimara), pelo intermédio das principais organizações dos movimentos dos povos indígenas equatorianos (Confederação das Nacionalidades Indígenas do Equador - CONAIE), bolivianos (Confederação dos Povos Indígenas de Bolívia CIDOB), peruanos (Confederação das Nacionalidades Indígenas do Peru - CONAIP) e andinos em geral (Coordenação Andina de Organizações Indígenas - CAOI). Essas organizações foram muito ativas durante os anos 90 do século XX, quando o conceito sumak kawsay transcendeu a Amazônia equatoriana (CUBILLO-GUEVARA; HIDALGOCAPITÁN, 2015).A incorporação da cosmovisão andina aos discursos do sumak kawsay 
(quíchua), allin kawsay (quíchua) e suma quamaña (aimara) aporta uma expressiva dimensão espiritual que permite qualificá-los, de forma elogiosa, como pachamamistas (CUBILLOGUEVARA; HIDALGO-CAPITÁN; DOMÍNGUEZ-GÓMEZ, 2014).

Nota-se também a incorporação de princípios andinos de reciprocidade e solidariedade (ayni, minga, randi-randi) que contribuem na criação de fortes vínculos comunitários entre seus praticantes. Com a incorporação desses elementos autênticos, ainda presentes nos cotidianos dos povos andinos, os intelectuais indígenas e indigenistas conseguiram recriar uma concepção de vida desejável que supostamente existiu no passado (CUBILLOGUEVARA, 2016)

$\mathrm{Na}$ Bolívia o termo suma qamaña, comumente traduzido como vivir bien, emerge nos anos 90, sobretudo das atividades da Confederação dos Povos Indígenas de Bolívia em interação com a CONAIE, e de um grupo de intelectuais indígenas e indigenistas de La Paz, direcionado pelas ideias de Simón Yampara, sociólogo aimara reconhecido como um dos principais interlocutores em formular e disseminar a noção de vivir bien, e Javier Medina, intelectual boliviano. Nesse contexto, a noção também emerge como um padrão alternativo ao desenvolvimento ocidental.

Salientamos a atuação política desses dois intelectuais, importante fator na disseminação da noção de vivir bien. Simón Yampara participou amplamente da política boliviana, como membro da Confederación Sindical Única de Trabajadores Campesinos de Bolivia (CSTUCB) e da Confederación Única, como ministro no governo de Víctor Paz Estenssoro, e nos anos posteriores da Federación de Juntas Vecinales de El Alto (FEJUVE). Javier Medina foi diretor do Fundo de Investimento Social (FIS) de Bolívia e a época decidiu introduzir a noção de vivir bien como uma política pública, aplicando-a a programas de participação popular, de educação e interculturalidade em Bolívia.

Nessa dinâmica intercultural, agentes europeus de cooperação internacional também participaram dos processos de disseminação das noções. Tais agentes financiaram vários estudos para identificar noções de bem viver de povos andinos e amazônicos como alternativas ao modelo desenvolvimentista ocidental ou ao desenvolvimento sustentável que estava sendo disseminado nos anos noventa. Alguns dos primeiros estudos sobre bem viver, como os publicados por Javier Medina (2001 e 2002) sobre o suma qamaña aimara e sobre o ñande reko guarani, foram financiadas pela agência de cooperação técnica alemã (GTZ-GIZ, organização de cooperação internacional do governo alemão), bem como a publicação dos 
trabalhos do argentino Dominique Temple (2003) sobre a teoria da reciprocidade. O Instituto Amazanga da Organização dos Povos Indígenas Pastaza no Equador (OPIP), de onde emergem os primeiros registros de sumak kawsay como buen vivir (Viteri et al., 1992; Viteri, 2000), foi financiado pela ONG italiana Terra Nuova e pela organização dinamarquesa IBIS no início dos anos noventa.

Antecedendo em mais de uma década a sistematização proposta por Viteri (2003), Descola (1986) descreveu a noção de shiir waras do povo achuar da Amazônia equatoriana, a qual ele traduziu como bien vivir, como sendo um fenômeno social ${ }^{1}$ relativo à forma e ideal de vida desse povo. Posteriormente, Mader (1999, 166-167) publicou resultados semelhantes de pesquisa realizada junto a outra comunidade da Amazônia equatoriana, a shuar, cujo conceito de pujustin pénker, foi traduzido como bien-estar ou vivir bien, sendo descrito de maneira similar ao shiir waras achuar, como um bem viver a que aspira toda pessoa shuar.

No Brasil, dentre a imensa diversidade de povos indígenas, são 305 etnias diferentes de acordo com o Censo 2010 do IBGE, destaca-se em volume a produção em torno das noções de bem viver dos povos Guarani, provavelmente devido ao expressivo número populacional dos Guarani face às demais etnias. Os povos Guarani constituem uma das populações indígenas de maior presença territorial no continente sul-americano, são povos que apresentam semelhanças nos aspectos fundamentais de sua cultura e organizações sociopolíticas, porém, diferentes no modo de falar a língua guarani, de praticar sua religião e aplicar as diversas tecnologias na relação com o meio ambiente (FUNAI, 2019).

Bartomeu Meliá, jesuíta, antropólogo e militante na luta em defesa dos territórios indígenas, estudou povos indígenas no Paraguai e no Brasil por mais de sessenta anos. Meliá afirma que para os povos Guarani, e outros povos da família Tupi-Guarani, com os quais conviveu longamente, o teko porã (bem viver) é uma noção que atravessa toda a experiência de vida, representando muito mais que uma filosofia $(2015$, p. 08$)$

Teko Porã é um modo de ser, um bom estado de vida, é um bem-viver e um viver bem, mais sentido do que filosofado. É um estado de ventura, de alegria e de satisfação; um estado feliz e prazeroso, pacífico e tranquilo. Há

1 Maturana e Varela (1995) procuram explicar o conhecer explicando o conhecedor e tomando como ponto de partida a experiência do observador e o observar. Esse observador não pode distinguir, na experiência, entre ilusão e percepção, mas pode gerar explicações da experiência que são reformulações da experiência. As explicações científicas, por exemplo, são reformulações da experiência aceitas pela comunidade científica por satisfazerem um critério de validação estabelecido por ela mesma, logo, o fenômeno social existe a partir do momento em que é percebido por um observador. 
um bem-viver quando existe harmonia com a natureza e com os membros da comunidade, quando existe alimentação suficiente, saúde e tranquilidade. É também identidade cultural plenamente vivenciada e livre de ameaças... O bem viver que um território proporciona - e necessita - se manifesta em um tipo de economia que os Guarani definiram como jopói, que é apenas a versão da economia de reciprocidade tão difundida em todo o mundo e desde os primeiros tempos da humanidade.

Em relação aos povos Guarani com os quais conviveu, Meliá também relata que embora migrações sazonais sejam frequentes, tais povos não eram, nem são nômades, ao contrário são agricultores e excelentes produtores de alimentos e as migrações se deram por diferentes motivos: um dos mais fortes foi, provavelmente, a busca da "terra-sem-mal" (2015). De acordo com o pesquisador "são males, para os Guarani, uma terra esgotada para a agricultura, uma paisagem desértica, um campo sem árvores ou, na atualidade, a produção de gado e as monoculturas da soja, eucalipto ou cana-de-açúcar, que ameaçam suas vidas e seus territórios" (p. 08, 2015).

Segundo Meliá (2015), aspectos espirituais são parte importante do modo de ser (teko porã) Guarani, orientando suas noções de pertencimento e de reciprocidade, enquanto experiência de vida compartilhada.

A ideia de "terra sem males" remete às utopias latino-americanas, bem como às suas relações com a religião, sobretudo o catolicismo. A atuação dos jesuítas junto aos povos indígenas desde o século XVI produziu, e continua a produzir, fenômenos e símbolos que dão margem a interpretações, sincretismos, imposições, assimilações e tantas outras dinâmicas entre as culturas envolvidas que talvez seja missão impossível definir se o termo "terra sem males" seria realmente uma simples tradução, assimilação cultural ou reinterpretação. Contudo o que se apresenta como evidência é o grande número de menções e associações entre noções de bem viver e a busca pela "terra sem males".

Graciela Chamorro, professora de História Indígena na Universidade da Grande Dourados, estuda povos Guarani há mais de três décadas, colaborando frequentemente com o Conselho Indigenista Missionário (CIMI). De acordo com Chamorro (2011, p. 03) "mais que simplesmente viver bem, bem viver, trata-se, fundamentalmente, de conviver bem, viver bem em comunidade". Segundo a autora, a metáfora do bem viver e seus reflexos estão relacionados às noções acadêmicas de interculturalidade e descolonização. A autora aponta que ao assumir outras cosmovisões, outros universos de sentido, a interculturalidade anda junto com a "descolonização dos saberes, da natureza e, também, de colonizados e colonizadores" (CHAMORRO, 2011, p. 04). 
A pesquisadora afirma que, para as comunidades Guarani com as quais convive, o divino está presente na natureza, nas plantas, nas pedras e em todos os seres vivos. Essa vertente também está relacionada a temores, por isso, eles rezam antes de caçar para aplacar a ira dos donos daquela caça. Os Guaranis acreditam que a natureza tem alma, tem vida própria e uma relação com seus seres protetores. Portanto, as noções de bem viver presentes entre os povos Guaranis estudados também apresentam aspectos espirituais/religiosos intrínsecos.

As noções de bem viver são encontradas em muitos povos originários no Brasil. Alcântara e Sampaio (2017) realizaram entrevistas semi-estruturadas com dez estudantes universitários de comunidades indígenas (a maioria da região amazônica): Warequena, Baníwa, Xukuru do Orurobá, Tariána, Terena, Arapaso e AtikumUmã. Os resultados sugerem que muitos elementos do cotidiano e do modo de vida dessas comunidades se assemelha a elementos presentes em outras noções de bem viver, por exemplo, as que são articuladas nas constituições do Equador e da Bolívia (ALCÂNTARA; SAMPAIO, 2017, p. 22)

Para os Arapáso, o bem viver está presente na solidariedade e na vida em comunidade... Na etnia dos Atikum, o bem biver está presente nas relações entre a comunidade e natureza... para os estudantes das comunidades do Amazonas Tariana e Baníwa [...] o bem viver está presente na cosmologia indígena, onde a terra é vista como patrimônio comum, resultando na preservação dos saberes tradicionais, cultura e nas relações com o outro e o meio

Fabiane da Silva Prestes (2018) investigou em seu projeto de doutorado as conexões entre os princípios da teoria do buen vivir (sumak kawsay) e os saberes tradicionais que orientam o modo de ser dos Kaingang, em territórios da Bacia Hidrográfica Taquari-Antas, Caí e Sinos. A pesquisadora afirma a existência de um kanhgág há kar (bem viver Kaingang) que tem suas bases fixadas nos saberes ancestrais daqueles que habitaram originariamente as Américas, mas que possui fundamentos específicos que foram construídos a partir das concepções deste coletivo indígena.

A pesquisadora argumenta que os Kaingang mantêm seu modo de ser numa perspectiva que muito se aproxima aos pressupostos da teoria/filosofia do buen vivir, notadamente, "os princípios: ancestralidade, cosmovisão, vida como prioridade, complementaridade, reciprocidade, harmonia, equilíbrio, relacionalidade, dualidade, tempo cíclico e concepção biocêntrica, estão presentes na organização atual deste coletivo indígena" (SILVA PRESTES, 2018, p. 228). 
Em 2015 o jornal Porantim (publicado pelo CIMI desde 1979) produziu o encarte pedagógico "O Bem Viver Indígena e o Futuro da Humanidade”, o qual reúne depoimentos de lideranças indígenas (Kreyê, Tupinambá, Kanamari dentre outros) de várias regiões do Brasil sobre suas noções e lutas pelo bem viver. As similaridades nas noções de bem viver dos povos originários vão para além do modo de viver, elas estão presentes também nos modos de lutar contra as injustiças e explorações que se perpetuam em toda a América, como reivindicado na fala de Kurá Kanamari, liderança indígena no Amazonas, "Estamos lutando para viver com nossa cultura, falar nossa língua, comer o peixe pescado na hora, sentir o cheiro da floresta, isso é o Bem Viver! Não é Bem Viver estar à beira da estrada, passar fome, sem a nossa terra, que é a nossa mãe" (p. 03). Os demais depoimentos nessa publicação ratificam como as noções do bem viver estão sendo empregadas por diferentes comunidades e movimentos indígenas em suas lutas pela recuperação e pela defesa de seus territórios.

O eixo indigenista, e de seus movimentos sociais, é o núcleo do pensamento do bem viver na América Latina. As noções de bem viver latino-americanas emergem a partir de cosmovisões indígenas, de sua autodeterminação e da continuidade de seus modos de vida tradicionais, com grande influência das noções de Pachamama (Mãe Terra), de deidades, rituais e tradições das culturas indígenas que convivem no continente. As cosmovisões indígenas amazônicas e andinas são os elementos centrais do presente debate. Como já pontuamos, embora seja um conjunto muito amplo e heterogêneo, foi a partir de cosmovisões indígenas amazônicas e andinas que emergiram as ideias sobre bem viver na América do Sul enquanto horizontes éticos e políticos.

\subsubsection{Perspectiva Estadista}

A perspectiva socialista e estadista é caracterizada pela influência dos pensamentos neomarxistas próprios dos intelectuais que estiveram próximos aos governos do Movimiento al Socialismo (MAS) de Evo Morales na Bolívia e de Alianza PAIS (Patria Altiva y Soberana) de Rafael Correa no Equador (SENPLADES, 2009, 2011). Nessa abordagem o bem viver é articulado como o socialismo do sumak kawsay, como socialismo comunitário andino ou como a variante equatoriana ou boliviana do socialismo do século XXI, com semelhanças ao desenvolvimento moderno em sua variante neomarxista (CUBILLO GUEVARA, 2016).

Através de um processo revolucionário conhecido como revolução cidadã no Equador e como revolução democrática e cultural na Bolívia, esses intelectuais tentaram implementar 
um novo modelo de desenvolvimento que buscava essencialmente ampliar a equidade (RAMÍREZ, 2010). De acordo com a Secretaria Nacional de Planejamento e Desenvolvimento do Equador (SENPLADES, 2011) esse modelo, em sua fase inicial, seria apoiado pelo extrativismo, enquanto se executava a transformação das matrizes produtivas desses países. Essa abordagem de bem viver se disseminou a partir de grupos de intelectuais dos governos do Equador e Bolívia aos círculos intelectuais de outros governos esquerdistas latino-americanos, tanto de pensamento bolivariano quanto social-democrata, muitos dos quais incorporaram a noção socialista em seu discurso político e estatista de bem viver.

Tal abordagem atribui grande relevância ao papel que o Estado deveria desempenhar na implementação do bem-estar (SENPLADES, 2011). Nesse contexto, o Estado se torna o principal agente político e, em teoria, o intérprete central da vontade popular. Por outro lado, os diferentes movimentos sociais (por exemplo, o movimento indígena ou ambiental), que contribuíram para colocar a noção de bem viver no centro do debate político, acabaram perdendo influência no campo das ações políticas. Essa polarização entre Estado e movimentos sociais é considerada por críticos da perspectiva estadista como uma descaracterização da perspectiva indigenista e das demandas originais dos movimentos indígenas (ACOSTA, 2015).

Os proponentes dessa corrente de pensamento também aspiram transformar os sistemas socioeconômicos latino-americanos em sistemas socioeconômicos pós-capitalistas, em economias com mercado, mas não de mercado, onde entidades da economia social e a solidariedade desempenham um papel central (CORAGGIO, 2007). Logo, o pós-capitalismo é o objetivo central da utilização de noções de bem viver na perspectiva estadista (HIDALGOCAPITÁN; CUBILLO-GUEVARA, 2014).

Apesar das contradições, há fatos concretos alcançados pela perspectiva estadista, como por exemplo, várias referências diretas a noções de bem viver e seus componentes na constituição de 2008 do Equador. Foram incorporadas referências às raízes milenares dos povos originários, à natureza (Pachamama), às diversas formas de religiosidade e espiritualidade e à heterogeneidade de culturas presentes no território, como exemplifica o excerto abaixo (ECUADOR, 2008, p. 01)

Apelando a la sabiduría de todas las culturas que nos enriquecen como sociedad, como herederos de las luchas sociales de liberación frente a todas las formas de dominación y colonialismo, y com un profundo compromiso con el presente y el futuro, decidimos construir una nueva forma de convivencia ciudadana, en diversidad y armonía con la naturaleza, para 
alcanzar el buen vivir, el sumak kawsay

$\mathrm{Na}$ Constituição Política do Estado Plurinacional da Bolívia há também referências diretas às noções de bem viver. Logo em seu preâmbulo estão registradas intenções de se estabelecer uma sociedade mais igualitária a partir da nova constituição, reivindicando respeito para com a diversidade cultural, a pluralidade da qual é formada o povo boliviano:

Un Estado basado en el respeto e igualdad entre todos, con principios de soberanía, dignidad, complementariedad, solidaridad, armonía y equidad en la distribución y redistribución del producto social, donde predomine la búsqueda del vivir bien; con respeto a la pluralidad económica, social, jurídica, política y cultural de los habitantes de esta tierra; en convivencia colectiva con acceso al agua, trabajo, educación, salud y vivienda para todos. Dejamos en el pasado el Estado colonial, republicano y neoliberal. (BOLIVIA, 2009)

Portanto, essas constituições, apresentam um novo pacto de convivência para suas sociedades, com propostas para a realização de mudanças estruturais, e a necessidade de atualizar a discussão sobre novos modos de produzir, consumir e organizar a vida. Um novo marco a partir do qual as políticas sociais deveriam se organizar. Note-se que ainda não entramos no mérito se esses objetivos foram de alguma forma realizados pelos governos que lhes propuseram. Após as quedas de Rafael Corrêa, em 2017, e Evo Morales, em 2019, tem ocorrido o desmonte das estratégias de bem viver em virtude da onda de ultraconservadorismo de direita que assola a América do Sul, um movimento retrógrado em função do neoliberalismo.

\subsubsection{Perspectiva Ecologista}

A perspectiva ecologista advém do pensamento ecologista e pós-desenvolvimentista, de intelectuais vinculados com a crítica do desenvolvimento e com os movimentos sociais latino-americanos (ACOSTA, 2014; GUDYNAS, 2011; QUIJANO, 2014; ESCOBAR, 2015), os quais defendem que as noções de bem viver são utopias a serem reconstruídas como expressões de modos de vida centrados em territórios.

Esses intelectuais rejeitam a ideia de que o desenvolvimento moderno seja uma aspiração social, e o consideram uma forma de dominação. Eles propõem a criação de processos locais de participação social, de maneira que cada comunidade possa definir seu próprio bem viver, ou bom conviver, e assegurem que a sustentabilidade ambiental seja um requisito central para a realização destes modos de vida (ACOSTA, 2014). 
Nesse contexto, tais autores sugerem a subordinação da necessidade de alcançar objetivos de equidade e identidade à necessidade de manter relações equilibradas com os territórios, com os espaços de vida, o que se alcançaria por meio dos "direitos da natureza" (ACOSTA; MARTÍNEZ, 2011); ideia essa cristalizada na Constituição equatoriana. Isso supõe implicitamente que essas economias se tornariam economias pós-extrativistas (GUDYNAS, 2011).

Tal perspectiva sobre as noções de bem viver tornou-se popular entre os movimentos ecologistas latino-americanos e europeus que consideram o conjunto dessas noções como a variante latino-americana do decrescimento ${ }^{2}$ e como uma das muitas estratégias possíveis para uma transição socioecológica (ESCOBAR, 2015). Essa perspectiva atribui grande importância ao papel da sociedade civil e, principalmente, dos movimentos sociais (indígenas, ambientalistas, feministas, trabalhadores, camponeses, pacifistas) na definição e realização de bem viver, e considera esses movimentos como os principais agentes políticos, que devem ser ouvidos e respeitados pelos governos latino-americanos.

Estes movimentos aspiram construir uma sociedade biocêntrica, onde o território ocupa o centro das preocupações dos cidadãos (GUDYNAS, 2011). De fato, o biocentrismo é o objetivo central do uso das noções de bem viver nessa perspectiva. A maior parte desses postulados corresponde a uma concepção pós-moderna do mundo de origem ocidental (HIDALGO-CAPITÁN; CUBILLO-GUEVARA, 2014).

Quando representantes do partido indigenista Pachakutik propuseram a incorporação do sumak kawsay na Constituição equatoriana, os representantes oficiais do partido Alianza País, liderados pelo presidente da Assembleia, Alberto Acosta, aceitaram o termo, traduzido como buen vivir, pois, ao ser um termo pouco discutido, poderia ser preenchido de conteúdo através de um processo participativo (CUBILLO-GUEVARA; HIDALGO-CAPITÁN, 2015). Assim, a Assembleia Constituinte do Equador, sob a presidência de Alberto Acosta, converteu-se em um fórum de reflexão sobre o bem viver.

2 Decrescimento pode ser considerado um imaginário político orientado à profunda transformação da sociedade, promovendo críticas filosóficas, culturais, ecológicas e econômicas ao capitalismo e seus conceitos de desenvolvimento e produtivismo. Sustentabilidade, bioeconomia e economia ecológica são discursos característicos desde imaginário. O conceito de decrescimento baseia-se, num primeiro momento, na crítica antropológica da modernidade e do homo economicus, e num segundo momento à ecologia (Escobar, 2015) 
O grande número de intelectuais equatorianos, latino-americanos e de outras nacionalidades envolvidos propiciou que a noção de bem viver constitucional equatoriana incorporasse várias vertentes teóricas. Logo, para além do pensamento pósdesenvolvimentista e ecologista, encontram-se fortes influências da teoria da colonialidade (a denúncia sobre o racismo estrutural das sociedades latino-americanas e propostas de decolonialidade do poder e do saber), a teoria da dependência (a denúncia das desigualdades sociais derivadas da inserção internacional das economias latino-americanas) e da teologia da libertação (com seu alinhamento em prol dos oprimidos).

Dentre as três perspectivas do bem viver, a perspectiva ecologista é a que teve a maior projeção internacional, com marcadas contribuições de intelectuais europeus, como os espanhóis José María Tortosa e Koldo Unceta, o português Boaventura de Sousa Santos (2016) e o belga François Houtart (2011), particularmente no campo acadêmico.

No contexto andino, um dos principais financiadores de publicações da perspectiva ecologista é a fundação alemã Rosa Luxemburgo, cuja sede andina conta com a colaboração de Alberto Acosta, Eduardo Gudynas, Maristella Svampa, Esperanza Martínez, Edgardo Lander, Margarita Aguinaga e Koldo Unceta.

A principal influência da perspectiva ecologista é a ecologia profunda, da qual deriva o conceito de biocentrismo, um elemento central dessa perspectiva (GUDYNAS, 2011). Este conceito refere-se a uma concepção de mundo em que o território, enquanto espaço de vida, é a medida para todas as coisas e, portanto, tem um valor intrínseco e independente da utilidade que tem para o ser humano.

Como uma colagem de diversas contribuições intelectuais, a perspectiva ecologista também reflete influências do movimento feminista latino-americano, notadamente as influências que se articulam e proliferam a cada Encontro Feminista da América Latina e do Caribe (EFLAC, 1981-2017). Reunindo representantes dos diferentes ramos do feminismo latino-americano desde 1981, o EFLAC já teve 14 edições e tem sido uma plataforma onde influências do ecofeminismo, do feminismo intercultural, do feminismo negro e do feminismo do cuidado, dentre outros, se articulam com noções de bem viver (VEGA, 2011).

No Brasil o feminismo negro ampliou a visibilidade das noções de bem viver através da "Marcha das Mulheres Negras 2015 - Contra o Racismo e a Violência e pelo Bem Viver: o Bem Viver como Nova Utopia”, a marcha mobilizou mais de 50 mil pessoas em Brasília e reivindicava equidade, solidariedade e bem-estar como valores inegociáveis. A noção de bem 
viver foi apresentada no manifesto da Marcha como uma plataforma para se construir coletivamente uma nova dinâmica de vida e ação política, por meio da superação do racismo, do sexismo e de todas as formas de discriminação.

Desde 2105, manifestações das "Marchas das Mulheres Negras" têm articulado noções de bem viver. Em 2020, a "Marcha das Mulheres Negras de São Paulo", apresentou o slogan "Nem cárcere, nem tiro, nem Covid: corpos negros vivos! Mulheres negras e indígenas! Por nós, por todas nós, pelo bem viver!" (MARCHA DAS MULHERES NEGRAS DE SÃO PAULO, 2020). No manifesto publicado pelo movimento expõe-se o retrocesso ético e político que tem assolado o país desde o golpe contra a presidente Dilma, em 2016. Afirma-se que o autoritarismo e o racismo estrutural, referendados pela política genocida do Estado, colaboram para o aumento das desigualdades econômicas, sociais e raciais, de modo que durante a pandemia, "a crise sanitária" expôs a maior vulnerabilidade de populações desprovidas de acesso a "direitos básicos de saúde, saneamento, educação e moradia", notadamente a população negra (MARCHA DAS MULHERES NEGRAS DE SÃO PAULO, 2020). A marcha realizada de forma virtual devido a restrições de circulação relacionadas à pandemia da Covid-19, apresentou em seu manifesto a seguinte abordagem sobre bem viver:

Reivindicamos o Bem Viver por ele resgatar as formas ancestrais de gestão do coletivo e do individual, com respeito aos nossos corpos e à natureza. Exigimos outra economia, sustentada nos princípios de solidariedade, reciprocidade, responsabilidade e integralidade. (MARCHA DAS MULHERES NEGRAS DE SÃO PAULO, 2020)

Logo, o bem viver é articulado, também, como expressão de potência de ação dos grupos sociais. Os movimentos envolvidos com a "Marcha" têm reivindicado o bem viver como um valor "inegociável", articulando-se "pelo bem viver e contra o genocídio do povo preto, povos indígenas, LGBTQIA+ e contra todas as formas de opressão" (MARCHA DAS MULHERES NEGRAS DE SÃO PAULO, 2020).

\subsubsection{Aspectos comuns entre as perspectivas}

Agentes de cooperação internacional, os governos do Equador e da Bolívia e suas Assembleias Constituintes, movimentos sociais latino-americanos, acadêmicos de diversos países se apropriaram dessas noções e contribuíram para dotá-las de um conteúdo mais amplo. Este hibridismo tem proporcionado destaque às noções de bem viver em diversos campos de estudo, sobretudo da sociologia, da ecologia, da economia política, da educação e da saúde. 
Tal pletora de noções, centradas em cosmovisões de povos indígenas da América, articuladas em teorias tão diversas refletem a dinâmica de conceitos em construção (ACOSTA, 2014). Como pérolas em formação, e de imenso potencial, estas noções em movimento evidenciam uma característica do pensamento latinoamericanista, a qual o pesquisador Bruno Simões Gonçalves (2019, p. 131) se refere como ethos barroco latinoamericano:

O ethos barroco se caracteriza pela intensa estetização da vida cotidiana, pela teatralização originada dessa dialética americana dos extremos, que afirma simultaneamente o mundo real e o mundo da ilusão, o mundo das formas e o mundo das ideias, a fruição dos sentidos e a angústia do espírito e inúmeras outras ambiguidades. Mais do que um fracasso ou ausência de escolha, o ethos barroco é a expressão dessas tensões em sua vigência mais vigorosa; é a afirmação desse movimento de oscilação entre um polo e outro.

Sob a luz deste ethos barroco, que aceita ambiguidades e diálogos entre extremos inconciliáveis, que em vez de fechar conceitos abre horizontes, consideramos que há elementos consensuais presentes em grande parte das noções de bem viver latino-americanas:

a) Centralidade das cosmovisões de povos indígenas da América;

b) Marcado caráter comunitário, uma ética de igualitarismo e divisão equânime da riqueza socialmente produzida por todos;

c) Propostas de relações mais equilibradas com o território, em oposição ao extrativismo predatório (ecologia, sustentabilidade, preservação);

d) Aporte espiritual, religioso ou místico;

e) Aportes de culturas e teorias diversas;

f) Propostas de novos sistemas sociopolítico-econômicos.

As noções são utilizadas por movimentos sociais de diversas naturezas, são inspiradas em diversos povos, estão presentes em muitos países, empregadas pelo Estado, incorporadas em constituições, presentes em instituições diversas. De acordo com o CFP (2019), são "práticas pessoais, comunitárias e coletivas que vão concretizando outro sentido histórico para além da colonialidade" (p. 76).

Em suma, o conjunto das noções de bem viver latino-americanas inclui propostas alternativas ao projeto de colonialidade, projetos históricos de descolonização da sociedade moderna, e enquanto "horizontes éticos e políticos alternativos" (PRESTES, 2018) carregam a proposta de uma relação integralizadora do ser humano com seu espaço de vida e demais 
seres, estimulando a revalorização da subjetividade através de cosmovisões ancestrais (CFP, 2019). 


\section{MÉTODO}

A revisão de escopo é um tipo de síntese de conhecimento que segue uma abordagem sistemática para mapear conceitos-chave que sustentam determinada área de pesquisa, mapear evidências sobre um tópico, clarificar definições operacionais e identificar lacunas no conhecimento de um campo de interesse (TRICCO et al., 2018). Este tipo de revisão de literatura tem como técnica mapear estudos relevantes no campo de interesse, neste sentido, é alternativamente chamada de mapeamento de literatura (ROCCO, 2018).

As revisões de escopo têm grande utilidade para explorar e sintetizar evidências de pesquisa em um campo novo, ou sobre um tópico ainda pouco explorado, e são frequentemente empregadas para mapear a literatura existente em termos de sua natureza, características e volume (PRESTES, 2018; TRICCO et al., 2016). De acordo com Moher, Stewart e Shekelle (2015), o uso de revisões de escopo é justificado quando o que se busca é uma visão geral de um campo amplo e não respostas detalhadas para perguntas específicas (como no caso de revisões sistemáticas). De acordo com Tricco et al. (2018, p. 467)

Scoping reviews can be conducted to meet various objectives. They may examine the extent (that is, size), range (variety), and nature (characteristics) of the evidence on a topic or question; determine the value of undertaking a systematic review; summarize findings from a body of knowledge that is heterogeneous in methods or discipline; or identify gaps in the literature to aid the planning and commissioning of future research

O uso de revisões de escopo tem crescido exponencialmente na área da saúde, sobretudo na área médica. Este crescimento tem motivado o estabelecimento de protocolos para assegurar a qualidade e transparência das pesquisas empregando este método. Um grupo de 24 pesquisadores associados à "Rede para Melhoria da Qualidade e Transparência de Pesquisas em Saúde" (Enhancing the Quality and Transparency of Health Research, EQUATOR Network) desenvolveu um protocolo para a realização de revisões de escopo, lançado em Setembro de 2018, na forma de uma lista de verificação contendo 22 itens (TRICCO et al., 2018).

O protocolo foi desenvolvido baseado no guia para realização de revisões sistemáticas (PRISMA - Preferred Reporting Items for Systematic reviews and Meta-Analyses) publicado pelo Instituto Joanna Briggs ${ }^{3}$ (JBI), e foi nomeado PRISMA-ScR (Preferred Reporting Items

3 O Instituto Joanna Briggs é uma organização internacional de pesquisa e desenvolvimento, sem fins lucrativos, vinculada a Faculdade de Ciências Médicas e da Saúde da Universidade de Adelaide, Austrália. 
for Systematic reviews and Meta-Analyses extension for Scoping Reviews).

O JBI já havia publicado em 2015 um manual para a realização de revisões de escopo, chamado “The Joanna Briggs Institute Reviewer's Manual 2015 - Methodology for Joanna Briggs Institute Scoping Reviews" (PETERS et al., 2015) que também foi empregado no desenvolvimento do presente estudo.

A utilização de um protocolo como o PRISMA-ScR (anexo 1) e do manual do JBI para realização de revisões de escopo, ambos validados por um número significante de instituições de ensino superior e pesquisadores de diferentes nacionalidades trabalhando paralelamente. O que aumenta o rigor científico, permite averiguação da qualidade metodológica e assegura a replicação da pesquisa.

Considerando que o tipo de revisão de literatura mais difundido no meio acadêmico é a revisão sistemática, Armstrong et al. (2011) produziram um quadro comparando revisões sistemáticas e de escopo no intuito de evidenciar as principais diferenças entre elas:

Quadro I. Comparação entre revisões sistemática e de escopo (2011)

\begin{tabular}{|l|lr|}
\hline Revisão Sistemática & Revisão de Escopo & \\
\hline $\begin{array}{l}\text { Questão de pesquisa bem determinada } \\
\text { com critérios rigorosos }\end{array}$ & $\begin{array}{l}\text { Questão ou questões de pesquisa } \\
\text { frequentemente amplas }\end{array}$ \\
\hline $\begin{array}{l}\text { Critérios de inclusão/exclusão geralmente } \\
\text { definidos a priori }\end{array}$ & $\begin{array}{l}\text { Critérios de inclusão/exclusão podem } \\
\text { ocorrer post hoc }\end{array}$ \\
\hline $\begin{array}{l}\text { Filtros de qualidade frequentemente } \\
\text { aplicados }\end{array}$ & $\begin{array}{l}\text { Qualidade não é } \\
\text { requisito/prioridade inicial }\end{array}$ \\
\hline Extração detalhada de dados & Extração de dados opcional \\
\hline $\begin{array}{l}\text { Síntese quantitativa frequentemente } \\
\text { executada }\end{array}$ & $\begin{array}{l}\text { Síntese tende a ser qualitativa e } \\
\text { tipicamente não quantitativa }\end{array}$ \\
\hline $\begin{array}{l}\text { Avaliação formal da qualidade dos } \\
\text { estudos e produção de uma conclusão } \\
\text { relacionada à questão da pesquisa }\end{array}$ & $\begin{array}{l}\text { Usada para identificar parâmetros e } \\
\text { lacunas no conhecimento de um campo }\end{array}$ \\
\hline
\end{tabular}

Fonte: Adaptado de Armstrong et al. (2011)

A realização de uma revisão de escopo é dividida em seis etapas principais (ARKSEY; OMALLEY, 2005; COLQUHOUN et al., 2014; PETERS et al., 2015). Essas etapas definem os processos utilizados nas diferentes fases da pesquisa, para que estes sejam conduzidos de

Ele é representado no Brasil pelo Centro Brasileiro para o Cuidado à Saúde Informado por Evidências, uma entidade coordenada pela Escola de Enfermagem e pelo Hospital Universitário da Universidade de São Paulo. 
uma forma rigorosa e transparente. "Os processos devem ser documentados em detalhes para permitir que o estudo possa ser replicado. Essa abordagem explícita de rigor metodológico aumenta a confiabilidade dos resultados" (ARKSEY; O'MALLEY, 2005). Baseando-nos no quadro de estrutura metodológica organizado por Colquhoun et al. (2014) e no manual para realização de revisões de escopo do Instituto Joanna Briggs (PETERS et al., 2015), apresentamos a seguir uma breve descrição e o desenvolvimento das seis etapas:

\subsection{Identificação da questão da pesquisa}

O ponto de partida de uma revisão de escopo é a identificação da questão da pesquisa a ser respondida. Ela servirá como uma bússola que auxilia na criação do roteiro para as etapas subsequentes. Os aspectos relevantes da questão (como população, contexto e conceito) devem ser bem definidos, pois eles têm consequências práticas para as estratégias de busca. As questões de pesquisa são de natureza ampla, pois procuram permitir vasta cobertura da literatura (ARKSEY; O’MALLEY, 2005). Decisões sobre critérios de exclusão de material podem ser aplicadas ou redefinidas uma vez que se tenha noção do volume e escopo da produção no campo.

Derivada do objetivo geral, a questão da pesquisa facilita a operacionalização do processo de revisão, delimitando o foco e facilitando a avaliação crítica da informação, além de tornar evidente ao leitor o propósito da revisão (TRICCO et al., 2018). No intuito de investigar a amplitude e sintetizar a produção sobre o tema escolhido, a questão da pesquisa deve ser ampla, "no ensejo de se alcançar a amplitude de respostas que se deseja" (ROCCO, 2018, p. 72). A questão que baliza a presente pesquisa é:

O que se tem produzido acerca das noções de bem viver latino-americanas no campo psi no século XXI?

\subsection{Identificação dos estudos relevantes.}

Envolve a identificação de estudos relevantes e o desenvolvimento de um plano contendo: onde procurar (fontes de informação e bases de dados), quais termos utilizar (palavras-chave), definição do período e idiomas. As fontes de informação podem ser: bases de dados eletrônicas, listas de referências, periódicos impressos, material produzido por organizações e conferências (ARKSEY; O’MALLEY, 2005). 


\subsubsection{Fontes de informação}

Para proporcionar uma visão ampla da temática, incluímos no escopo da pesquisa bases de dados tradicionais e fontes de informação não controladas por organizações editoriais comerciais. A escolha das bases de dados tradicionais teve por critérios sua relevância na área da Psicologia, no âmbito global e na América Latina, sua abrangência e credibilidade acadêmica. Como resultado, as seguintes bases foram utilizadas: Lilacs, Psycinfo, Redalyc, Scopus, Scielo e Web of Science.

De acordo com Adams et al. (2016) são consideradas referências bibliográficas tradicionais para o desenvolvimento de trabalhos científicos textos publicados em periódicos científicos, anais de congressos ou livros, ao atingirem critérios de aceitação ou seleção de editores que atestam a qualidade dos conceitos emitidos ou dos procedimentos metodológicos utilizados. Tais fontes são consideradas literatura científica. Contudo, os autores ressaltam o crescimento do uso de fontes "não convencionais" de informação (p. 12), ou seja, de registros (documentos, vídeos e conteúdo na internet) produzidos nos âmbitos governamental, comercial e dos movimentos sociais. De forma ampla, os autores consideram literatura não convencional documentos não controlados por organizações editoriais comerciais, por exemplo: relatórios de pesquisa, relatórios técnicos, teses, dissertações e documentos governamentais (ADAMS et al., 2016).

Para a inclusão de literatura não convencional, utilizamos, sobretudo, as bases de dados Dedalus, Google Acadêmico, Youtube, Portal de Periódicos da CAPES e ProQuest, além de fontes que nos foram transmitidas direta ou indiretamente por pesquisadores do termo, seja através de entrevistas, congressos ou por referências encontradas em suas obras. O quadro II abaixo apresenta as principais fontes de coleta de informação da presente pesquisa.

\section{Quadro II. Fontes de Informação (2020)}

\begin{tabular}{|l|l|}
\hline BASE DE DADOS & DESCRIÇÃO \\
\hline Dedalus & $\begin{array}{l}\text { Catálogo geral de consulta que permite pesquisar todas as obras de } \\
\text { interesse acadêmico e geral, distribuídas pelos acervos das } \\
\text { bibliotecas da Universidade de São Paulo (USP), incluindo livros, } \\
\text { monografias, teses, dissertações, revistas, artigos e outros trabalhos } \\
\text { de produção docente }\end{array}$ \\
\hline Google Acadêmico & Ferramenta de grande abrangência incluindo literatura científica e \\
\hline
\end{tabular}




\begin{tabular}{|c|c|}
\hline & $\begin{array}{l}\text { não convencional. Útil para pesquisar várias disciplinas e fontes em } \\
\text { uma mesma ferramenta. Alcança grande variedade de itens de } \\
\text { informação como: artigos de periódicos; teses e dissertações; livros; } \\
\text { resumos apresentados em eventos científicos; artigos de editoras e } \\
\text { textos de organizações profissionais; bibliotecas de universidades e } \\
\text { outras entidades acadêmicas }\end{array}$ \\
\hline Lilacs & $\begin{array}{l}\text { O mais abrangente índice da literatura científica e técnica Latino- } \\
\text { Americana e do Caribe em ciências da saúde. Indexa mais de } 900 \\
\text { periódicos, além de monografias, teses, livros, capítulos de livros, } \\
\text { anais de congressos e publicações governamentais }\end{array}$ \\
\hline $\begin{array}{l}\text { Portal de periódicos } \\
\text { da CAPES }\end{array}$ & $\begin{array}{l}\text { O Portal de Periódicos, da Coordenação de Aperfeiçoamento de } \\
\text { Pessoal de Nível Superior (CAPES), é uma biblioteca virtual que } \\
\text { disponibiliza a instituições de ensino e pesquisa no Brasil amplo } \\
\text { conteúdo da produção científica. Ele conta com um acervo de mais } \\
\text { de } 45 \text { mil títulos com texto completo, } 130 \text { bases referenciais, } 12 \\
\text { bases dedicadas exclusivamente a patentes, além de livros, } \\
\text { enciclopédias e obras de referência, normas técnicas, estatísticas e } \\
\text { conteúdo audiovisual }\end{array}$ \\
\hline ProQuest & $\begin{array}{l}\text { Principal base de teses e dissertações em texto completo do mundo, } \\
\text { a ProQuest é o depósito oficial de tais documentos nos Estados } \\
\text { Unidos e Canadá, além de permitir o depósito de documentos de } \\
\text { outras instituições cadastradas. Indexa uma ampla variedade de } \\
\text { itens: periódicos científicos, revistas comerciais, livros, registros de } \\
\text { trabalho, monografias, dissertações e teses, anais de conferência } \\
\text { jornais, blogs e podcasts, relatórios, normas e diretrizes práticas, } \\
\text { documentos de trabalho, vídeos e áudio, entre outras fontes }\end{array}$ \\
\hline PsycInfo & $\begin{array}{l}\text { Centrada em psicologia e ciências comportamentais, é um dos } \\
\text { principais repositórios na área. Possui mais de quatro milhões de } \\
\text { registros e recebe mais de quatro mil registros científicos indexados } \\
\text { semanalmente. Indexa mais de } 2.500 \text { jornais acadêmicos e é } \\
\text { utilizada em mais de } 60 \text { países }\end{array}$ \\
\hline Redalyc & Rede de Revistas Científicas da América Latina e Caribe, Espanha e \\
\hline
\end{tabular}




\begin{tabular}{|c|c|}
\hline & $\begin{array}{l}\text { Portugal é uma iniciativa de acesso aberto à produção científica em } \\
\text { periódicos ibero-americanos, que abrange todas as áreas do } \\
\text { conhecimento. É um projeto suportado pela Universidade } \\
\text { Autônoma do Estado do México com a ajuda de numerosas outras } \\
\text { instituições de ensino superior ibero-americanas. Indexa mais de } \\
1.300 \text { periódicos }\end{array}$ \\
\hline Scielo & $\begin{array}{l}\text { Biblioteca eletrônica que abrange uma coleção selecionada de } 298 \\
\text { periódicos científicos brasileiros. Resulta de um projeto da } \\
\text { FAPESP - Fundação de Amparo à Pesquisa do Estado de São } \\
\text { Paulo, em parceria com a BIREME - Centro Latino-Americano e } \\
\text { do Caribe de Informação em Ciências da Saúde }\end{array}$ \\
\hline Scopus & $\begin{array}{l}\text { A maior base de dados multidisciplinar de resumos e citações da } \\
\text { literatura revisada por especialistas do mundo, reúne: periódicos } \\
\text { científicos, livros e anais de congressos. Produzida pela editora } \\
\text { Elsevier desde } 2004 \text {, contém mais de } 71 \text { milhões de registros. } \\
\text { Possibilita a visualização de artigos mais citados e do Índice } \mathrm{H}^{4}\end{array}$ \\
\hline Web of Science & $\begin{array}{l}\text { Base multidisciplinar que indexa somente os periódicos mais } \\
\text { citados em suas respectivas áreas. Abrange as áreas de ciências } \\
\text { exatas e naturais, ciências sociais, artes e humanidades, permitindo } \\
\text { levantamento bibliográfico por assunto, autor e título. Indexa mais } \\
\text { de } 33.000 \text { periódicos. Possibilita a visualização de artigos mais } \\
\text { citados, Índice H e fator de impacto do periódico }\end{array}$ \\
\hline Youtube & $\begin{array}{l}\text { A maior plataforma virtual aberta de compartilhamento de media } \\
\text { audiovisual do mundo, com mais de dois bilhões de usuários ativos }\end{array}$ \\
\hline
\end{tabular}

4 O Índice H é um indicativo de qualidade e de notoriedade no segmento científico. Trata-se do número de artigos com citações maiores ou iguais ao número do índice $(\mathrm{H})$. Se uma pesquisadora tem H 5 quer dizer que ela teve 5 artigos que receberam igualmente 5 ou mais citações. O Ministério da Educação disponibiliza uma ferramenta de busca através da CAPES para as pesquisas de trabalhos científicos que permite encontrar artigos de uma autora e assim efetuar o cálculo de citações já feitas. (QUE FERRAMENTA $i$ PRECISA COMPLEMENTAR A INFORMAÇÃO E O ACESSO A FERRAMENTA, O LINK. DO CONTRÁRIO É MELHOR RETIRAR ESSA INFORMAÇÃO) 


\subsubsection{Estratégia de busca}

O período considerado para esta investigação foi de Janeiro de 2000 a Abril de 2020. As noções de bem viver ganham notoriedade global a partir anos de 2007 e 2008, sobretudo, devido aos movimentos políticos plurinacionalistas na Bolívia e no Equador. Desse modo, decidimos investigar produções do século XXI para possibilitar que fontes que antecedem tais movimentos políticos também pudessem ser analisadas.

Nesta etapa o objetivo é selecionar estudos no campo psi, ou relevantes para o campo, com conteúdo relacionado às noções de bem viver na América Latina. Levando em consideração as bases de dados selecionadas, decidimos incluir material publicado nos idiomas espanhol, inglês e português. A inclusão de estudos em inglês é relevante porque permite envolver bases de dados reconhecidas no campo psi, como a PsycInfo, e nos permite avaliar se e como pesquisadores em outras regiões do Sul Global estão considerando o tema. Um indicador disso é que durante nossas pesquisas iniciais encontramos filosofias similares ao bem viver nas culturas africanas e indianas em material publicado no idioma inglês (SIQUEIRA; SANTOS, 2018).

Baseada em nossa crescente familiaridade com a literatura sobre o tema, averiguamos que independente do idioma de publicação dos estudos (artigos, livros, teses e afins) o termo que nos interessa como palavra-chave consta na maior parte das fontes de informação em espanhol, ou seja, Buen Vivir. A tradução literal do termo Buen Vivir para o idioma Inglês não incidiu em conteúdo relevante, quando o tema consta em obras em Inglês ele é indexado como Buen Vivir, portanto, o termo good living foi descartado. Outras formas encontradas como palavras-chave são os termos: Bem Viver, Vivir Bien (Bolívia), Sumak Kawsay/Alli Kawsay/Allin Kawsay (Quíchua), Suma Qamaña (Aimara) Teko Porã/Teko Kavi/Nandereko/Nhandereko (Guarani). Portanto, como palavras-chave foram utilizadas na pesquisa:

- Os termos exatos: buen vivir, bem viver, vivir bien, sumak kawsay, allin kawsay, alli kawsay, suma qamaña, teko porã, teko kavi, ñandereko ou nhandereko.

- Associados a termos da psicologia como: psicologia, psicológico, psicológica, psique, psíquico. Nas bases de dados que comportam a utilização de busca booleana, utilizamos opções de truncamento: psi*, psy*.

Como mencionado anteriormente, salientamos que o método em uso contempla a utilização de critérios post hoc de inclusão e exclusão. Em se tratando de um método que visa 
o estudo de temas inovadores, ou pouco explorados, é esperado que a familiaridade dos pesquisadores com o tema aumente durante o desenvolvimento da revisão, justificando assim processos iterativos (cíclicos) de adaptação de critérios (ARKSEY; O’MALLEY, 2005; COLQUHOUN et al., 2014).

Em síntese, foram adotados os seguintes critérios de busca:

- Estudos publicados a partir do ano 2000;

- Idiomas: espanhol, inglês e português;

- Os estudos estarem disponíveis na íntegra;

- Conter um dos termos exatos: buen vivir, bem viver, vivir bien, sumak kawsay, alli kawsay, allin kawsay, suma qamaña, teko porã, teko kavi, ñandereko ou nhandereko;

- Conter uma das palavras-chave: psicologia, psicológico, psicológica, psíquico, psychology, psychological (a busca booleana foi utilizada sempre quando suportada pela base de dados, nesse caso no formato psico* ou psyc*).

De acordo com Peters et al. (2015), o auxílio de biblioteconomistas ou cientistas da informação pode ser de grande valia para o desenho ou refinamento de estratégias de busca. Para o desenvolvimento do presente estudo, contamos principalmente com a ajuda da equipe de bibliotecárias da Biblioteca Dante Moreira Leite do Instituto de Psicologia da Universidade de São Paulo. Foram de grande utilidade os cursos frequentados nessa biblioteca, notadamente, o "Curso Bases de dados: onde pesquisar" e o "Curso Artigo Científico: dos fundamentos à submissão".

Em suma, a criação de uma revisão de escopo envolve processos amplamente iterativos que são atualizados conforme seus criadores desenvolvem maior familiaridade com o tema de interesse através dos estudos encontrados, do corpo de evidências disponível, de interações com outros pesquisadores, de palavras-chave adicionais e de novos termos que podem ser incorporados à estratégia de busca.

\subsubsection{Aspectos Práticos}

A duração da presente pesquisa foi de 24 meses. Este período foi determinado de acordo com as normas do Programa de Pós-Graduação em Psicologia Social do Instituto de Psicologia da Universidade de São Paulo. 
Outro aspecto importante é que a presença de um segundo revisor/avaliador não é um requisito unânime na literatura que baliza este tipo de revisão (ROCCO, 2018). Devido a questões operacionais, a análise das obras foi realizada somente por este pesquisador.

\subsection{Seleção dos estudos}

A seleção dos estudos envolve a aplicação de critérios de inclusão e exclusão que são definidos após apreciação dos estudos obtidos na fase anterior, estes critérios são, portanto, considerados critérios post hoc. Tais critérios são definidos a partir das especificidades da questão de pesquisa e da familiaridade dos pesquisadores com o tema da pesquisa (fator que aumenta no desenrolar da pesquisa, através da leitura dos estudos).

Salientamos que esta seleção não é um processo linear, ao contrário, é um processo iterativo (cíclico) que envolve pesquisar a literatura, refinar a estratégia de busca e analisar referências para inclusão no estudo (LEVAC; COLQUHOUN; O'BRIEN, 2010)

No intuito de aumentar a transparência deste mapeamento da literatura, possibilitar sua replicação e facilitar pesquisas futuras especificamos abaixo detalhes da estratégia de busca nas bases de dados utilizadas.

Em nossa revisão foi necessário considerar especificidades do mecanismo de busca disponível em cada base de dados, pois as possibilidades de filtro, categorias e classificações variam de uma base para outra. Abaixo a descrição das estratégias empregadas em cada base de dados.

Dedalus: a pesquisa com os termos exatos do bem viver resultou em 56 itens. Critérios de busca:

- Estudos publicados a partir do ano 2000;

- Idiomas: espanhol, inglês e português;

- Conter um dos termos referentes às noções de bem viver: "buen vivir" OR "bem viver” OR “vivir bien” OR “sumak kawsay” OR “alli kawsay” OR “allin kawsay” OR

“suma qamana” OR “teko pora” OR “teko kavi” OR nandereko OR nhandereko.

Google Acadêmico: este mecanismo de pesquisa possui funções limitadas e sua abrangência é extremamente ampla. A busca avançada dentro dos critérios iniciais que estabelecemos (a combinação dos termos relacionados ao bem viver, para artigos nos três idiomas definidos) retornou mais de 16.000 itens. Não há opção de filtros por categoria ou campo do conhecimento, assim, para refinarmos a busca adicionamos os termos relativos ao 
campo psi (psi* OR psy*), com retorno de 6.490 obras.

Finalmente, como as opções de filtros são restritas, decidimos utilizar esta base para obras publicadas antes de 2008 (antecedendo a notoriedade global do tópico) e após 2019 (visando as obras mais recentes da literatura não convencional) o que resultou em 239 obras.

Lilacs: utilizando a busca por um dos termos do bem viver detalhados abaixo encontramos 30 documentos.

- Estudos publicados a partir do ano 2000;

- Idiomas: espanhol, inglês e português;

- Conter um dos termos referentes às noções de bem viver: "buen vivir" OR "bem viver” OR “vivir bien” OR “sumak kawsay” OR “alli kawsay” OR “allin kawsay” OR “suma qamana” OR “teko pora” OR “teko kavi” OR nandereko OR nhandereko.

Portal de Periódicos da CAPES: este portal abrange uma variedade de banco de dados, inclusive ampla cobertura de teses e dissertações, por isso foi incluído dentre as fontes de literatura não convencional. Para filtrar o grande número de obras encontradas nesta coleção, adicionamos aos critérios de busca os termos referentes aos povos indígenas: aborig*, indig*, nativ*, "povos originários", "pueblos originarios" ou "original peoples". O que resultou em 201 obras. Para isso os critérios utilizados foram:

- Estudos publicados a partir do ano 2000;

- Idiomas: espanhol, inglês e português;

- Conter um dos termos referentes às noções de bem viver: "buen vivir" OR "bem viver” OR “vivir bien” OR “sumak kawsay” OR “alli kawsay” OR “allin kawsay” OR “suma qamana” OR “teko pora” OR “teko kavi” OR nandereko OR nhandereko;

- Conter um dos termos: psi* OR psy*;

- Conter um dos termos para povos indígenas: aborig* OR indig* OR nativ* OR "povos originários" OR “pueblos originarios” OR “original peoples”.

Proquest: A ferramenta de busca do site permite selecionar os bancos de dados mais relevantes, logo foram selecionados os referentes às Ciências Sociais e excluídos os de Engenharia e Tecnologia. A pesquisa combinada dos termos resultou em 52 resultados. Critérios de busca aplicados:

- Estudos publicados a partir do ano 2000;

- Idiomas: espanhol, inglês e português; 
- Conter um dos termos referentes às noções de bem viver: "buen vivir" OR "bem viver” OR “vivir bien” OR “sumak kawsay” OR “alli kawsay” OR “allin kawsay” OR “suma qamana” OR “teko pora” OR “teko kavi” OR nandereko OR nhandereko;

- Conter um dos termos: psi* OR psy*.

PsycInfo: Embora seja um dos principais repositórios de estudos científicos em Psicologia do mundo, a busca por termos referentes às noções de bem viver retornou somente 18 resultados. Aplicamos critérios de inclusão mínimos, conforme segue:

- Estudos publicados a partir do ano 2000;

- Idiomas: espanhol, inglês e português;

- Conter um dos termos referentes às noções de bem viver: "buen vivir" OR "bem viver” OR “vivir bien” OR “sumak kawsay” OR “alli kawsay” OR “allin kawsay” OR “suma qamana” OR “teko pora” OR “teko kavi” OR nandereko OR nhandereko.

Redalyc: A base de dados Redalyc apresentou um amplo número de resultados. Esta base possui o filtro "Disciplinas" onde consta a categoria Psicologia. Aplicando o filtro obtivemos um total de 124 artigos dentro da categoria Psicologia. Critérios de busca aplicados:

- Estudos publicados a partir do ano 2000;

- Idiomas: espanhol, inglês e português;

- Conter um dos termos referentes às noções de bem viver: "buen vivir" OR "bem viver” OR “vivir bien” OR “sumak kawsay” OR “alli kawsay” OR “allin kawsay” OR “suma qamana” OR “teko pora” OR “teko kavi” OR nandereko OR nhandereko;

- Filtros da base de dados por disciplina: Psicologia.

Scielo: A pesquisa dentro do período desejado, resultou em 171 arquivos. Critérios de busca aplicados:

- Estudos publicados a partir do ano 2000;

- Idiomas: espanhol, inglês e português;

- Conter um dos termos referentes às noções de bem viver: "buen vivir" OR "bem viver” OR “vivir bien” OR “sumak kawsay” OR “alli kawsay” OR “allin kawsay” OR "suma qamana” OR “teko pora” OR “teko kavi” OR nandereko OR nhandereko.

Scopus: Nesta base encontramos 1.501 obras. Para filtrar os resultados pertinentes ao campo psi realizamos nova busca acrescentando os termos: psyc* OR psi*, resultando em 277 
obras. Finalmente acrescentamos aos critérios os termos relativos aos povos indígenas (descritos abaixo). Foram encontrados um total de 40 obras. Critérios de busca aplicados:

- Estudos publicados a partir do ano 2000;

- Idiomas: espanhol, inglês e português;

- Conter um dos termos referentes às noções de bem viver: "buen vivir" OR "bem viver” OR “vivir bien” OR “sumak kawsay” OR “alli kawsay” OR “allin kawsay” OR “suma qamana” OR “teko pora” OR “teko kavi” OR nandereko OR nhandereko;

- Conter um dos termos: psy* OR psi*;

- Conter um dos termos para povos indígenas: indig* OR nativ* OR "povos originários" OR “pueblos originários" OR “original peopl*”.

Web of Science: Esta base oferece filtros específicos por disciplina. Ao combinarmos o filtro "Disciplina Psicologia" e os termos de busca das noções de bem viver encontramos somente um item cadastrado. Neste caso, expandimos a busca para incluir mais disciplinas relacionadas: Antropologia, Ciências Sociais Interdisciplinares, Estudos de Gênero, Filosofia, Humanidades Multidisciplinar, Estudos Culturais, Pesquisa Educacional, Sociologia, Trabalho Social. Com esta combinação de filtros e critérios obtivemos o total de 64 resultados. Critérios de busca aplicados:

- Estudos publicados a partir do ano 2000;

- Idiomas: espanhol, inglês e português;

- Conter um dos termos referentes às noções de bem viver: "buen vivir" OR "bem viver” OR “vivir bien” OR “sumak kawsay” OR “alli kawsay” OR “allin kawsay” OR “suma qamana” OR “teko pora” OR “teko kavi” OR nandereko OR nhandereko;

- Filtros da base de dados por disciplina: Antropologia, Ciências Sociais Interdisciplinares, Estudos de Gênero, Filosofia, Humanidades Multidisciplinar, Estudos Culturais, Psicologia Social, Psicologia Multidisciplinar, Sociologia, Trabalho Social.

Youtube: A maior plataforma online aberta de produções audiovisuais oferece uma ferramenta de busca extremamente básica. Dentre as poucas opções, é possível buscar por termos em sequência (sem a necessidade de um operador booleano), forçar a associação entre termos (utilizando o símbolo “+” entre os termos), forçar a exclusão de resultados baseados em um termo (utilizando o símbolo “-”). 
Alguns filtros básicos são oferecidos somente para organizar os resultados de uma busca, é possível organizar por: número de visualizações, data de publicação, duração da obra, tipo da obra (filme, programa, canal etc.) ou característica relativa à qualidade do arquivo.

Executamos buscas específicas para cada termo referente às noções de bem viver e selecionamos oito vídeos dentre os mais vistos, procurando oferecer uma variedade de fontes, países e perspectivas.

\subsubsection{Critérios de exclusão}

Foram excluídas obras repetidas e que não apresentavam conteúdo explicitamente relevante ao campo psi, ou seja, que não respondiam à questão central da pesquisa. Salientamos que a revisão de escopo não prevê a exclusão de obras segundo critérios de qualidade metodológica, sendo assim, foram consideradas obras com diferentes abordagens metodológicas (ROCCO, 2018). Em relação ao período, como já mencionado, foram consideradas obras publicadas entre Janeiro de 2000 e Abril de 2020.

\subsubsection{Triagem e seleção das obras}

Do total das obras encontradas $(n=960)$ foram retiradas as obras duplicadas $(592)$. Em seguida, baseando-nos na pergunta da pesquisa, procedemos com a leitura dos títulos, fase onde excluímos 267 obras, notadamente o termo em português (bem viver) trouxe uma enorme variedade de pesquisas que não estão relacionadas com noções de bem viver latinoamericanas. Restaram para fase de leitura 101 obras.

As obras excluídas demonstram como os termos têm sido usados nas produções científicas de modo diverso, a maioria dessas obras aborda o bem viver de modo geral, como sinônimo de vida alegre, bem-estar ou desejo de boas sensações.

Seguindo o protocolo de revisões de escopo (PRISMA-ScR, anexo 1), apresentamos alguns exemplos de obras excluídas pelo título: "O bem-viver contemporâneo em revistas: uma análise do tensionamento entre consumo e simplicidade no discurso da Vida Simples" de Reginatto e Amaral (2013), "Percepção de idosos, moradores de uma instituição de longa permanência de um município do interior do Rio Grande do Sul, sobre qualidade de vida" de Brandão e Zatt (2015), "Nível de estresse de uma equipe de enfermagem do setor de neurologia de um hospital público: um relato de experiência" de Alves et al. (2015), "Psychological distress, individualism and the use o psychotropic medications: mental health 
and contemporary individuality" de Perrusi (2015), "Saúde e relações de gênero: notas de um diário de campo sobre vivência de rua" de Santos e Bemdos (2017), "Fenomenologia e Capoeira: jogos ludomotrícios na formação da criança na fase puer” de Arruda (2017).

Finalmente, após leitura das obras completas, concluímos que 79 obras se enquadram aos critérios desta revisão. O quadro III apresentado abaixo sintetiza o processo de busca desde a coleta inicial até a seleção final das obras para análise 
Quadro III. Síntese do processo de busca (2020)

\begin{tabular}{|l|l|l|}
\hline & Base de dados & Itens \\
& Dedalus & 51 \\
& Google Acadêmico & 239 \\
& Lilacs & 33 \\
& Portal Periódicos CAPES & 201 \\
& ProQuest & 32 \\
Identificação & PsycInfo & 18 \\
& Redalyc & 124 \\
& Scielo & 171 \\
& Scopus & 19 \\
& Web of science & 64 \\
& Youtube & 8 \\
\hline Selecionadas & Obras selecionadas (n=960) & \\
\hline Triagem & Obras retidas após a exclusão de duplicadas (n=368) \\
\hline Elegibilidade & Selecionadas após leitura de título (n=101) \\
\hline Incluídas & Incluídas na revisão (n=79) \\
\hline
\end{tabular}

\subsection{Mapeamento dos dados}

Nesta etapa realizamos a sistematização dos dados mais relevantes encontrados nos estudos selecionados, ou seja, os dados que respondem à questão direcionadora desta revisão. Segundo Rocco (2018), esta etapa contempla a criação de um banco de dados que simplifica o acesso aos elementos-chave de informações obtidas através da pesquisa, bem como seu gerenciamento.

De acordo com o protocolo de revisões de escopo (PRISMA-ScR, anexo 1), esta etapa requer a aplicação de um quadro analítico comum e coleta de informações padronizadas sobre cada estudo selecionado.

O quadro analítico é um formulário para extração sistemática de dados de cada estudo, contemplando variáveis relevantes para responder à questão da pesquisa. Note-se que o mapeamento também é um processo iterativo, os pesquisadores ao extraírem dados podem 
atualizar o formulário de mapeamento de dados.

\subsubsection{Teste piloto de extração de dados}

Os manuais sobre revisão de escopo (PETERS et al., 2015) sugerem que um teste piloto da extração de dados seja feito com ao menos cinco estudos, para assegurar que o formulário esteja alinhado com a pergunta e o propósito da pesquisa.

O teste piloto, como um processo iterativo, foi de grande ajuda para refinar o quadro analítico e assegurar que as variáveis selecionadas efetivamente ajudem a responder a questão da pesquisa. Através do teste simplificamos o quadro analítico para que nele constem somente variáveis que serão usadas na análise de dados. O teste piloto está disponível na seção apêndices (apêndice A). Abaixo apresentamos o quadro analítico final (quadro IV).

Quadro IV. Quadro analítico final (2019)

\begin{tabular}{|c|c|}
\hline \multicolumn{2}{|r|}{ Quadro analítico } \\
\hline Ano de publicação & Ano em que o item foi publicado \\
\hline Autoria & Nomes completos, iniciando pelo último sobrenome \\
\hline Título da obra & Citado exatamente como publicado \\
\hline Publicação & Título do periódico, publicação ou instituição que veicula a obra \\
\hline Localização da obra & País, região, cidade ou contexto da intervenção (se aplicável) \\
\hline Tipo de obra & Artigo, dissertação, monografia, tese, livro, entre outros \\
\hline Método & Breve descrição dos métodos empregados \\
\hline $\begin{array}{l}\text { Conceitos e temas relacionados à } \\
\text { Psicologia }\end{array}$ & $\begin{array}{l}\text { Descrição de conceitos e temas relevantes no campo da Psicologia. } \\
\text { Extração rigorosa de dados originais, conforme apresentado pelos } \\
\text { autores, incluindo indicação de página, se possível. Interpretações } \\
\text { devem ser evitadas neste campo }\end{array}$ \\
\hline Descritores e termos do bem viver & $\begin{array}{l}\text { Buen vivir, vivir bien, bem viver, sumak kawsay, suma qamaña, } \\
\text { teko porã, teko kavi, nande reko, nhandereko, ubuntu e afins }\end{array}$ \\
\hline
\end{tabular}




\section{AGRUPAMENTO, SÍNTESE E DISCUSSÃO DOS RESULTADOS}

Enquanto em uma revisão sistemática tradicional se produz uma síntese das evidências, ou se agrega achados de diferentes estudos, na revisão de escopo se produz uma visão geral de todo o material analisado, incluindo a discussão crítica de uma porção representativa do material.

Nesta etapa os esforços se concentram em ter a informação pautada a partir dos estudos elencados e em apresentar a narrativa dos resultados (DEPOLE, 2018). Dois passos são importantes nessa direção: análise da extensão e natureza dos dados e discussão sobre os dados considerados.

\subsection{Análise da extensão e natureza das obras utilizadas}

Etapa para identificação das áreas dominantes na produção sobre o tema, como tendências, métodos de pesquisa e localização geográfica. Também permite identificar oportunidades para estudos futuros. O quadro analítico das obras selecionadas para esta revisão encontra-se na seção apêndices (apêndice B).

O gráfico I abaixo ilustra a distribuição geográfica das obras selecionadas e o gráfico II o tipo de obras (artigo, capítulo de livro, tese, dissertação). Encontramos no Brasil o maior número de obras, com destaque para o número de pesquisas envolvendo os povos Guarani, a psicologia indígena e um estudo bibliométrico sobre o bem viver em periódicos qualificados.

Inferimos que o maior volume de produções no Brasil esteja relacionado com os limites de nossa pesquisa, em associação a questões populacionais. Nossos termos de busca são relacionados ao campo psi, como consequência, estes termos tendem a estar associados a obras do âmbito acadêmico, o que por sua vez se vincula ao número de instituições de ensino no país e o volume de pessoas vinculadas a elas.

Era esperado que Equador e Bolívia se destacassem na quantidade de produções pelo pioneirismo da discussão no âmbito político e dos movimentos sociais, pelos avanços alcançados em suas respectivas constituições. Destacamos que o Equador manteve por vários anos uma Secretaría del Buen Vivir, que fez investimentos específicos na promoção e no desenvolvimento de noções de bem viver, a qual produziu e promoveu a publicação de estudos, encartes, vídeos e outros materiais de comunicação.

A Colômbia apresenta um número de obras similar ao da Bolívia, mesmo sem contar 
com a popularidade do termo nos patamares governamentais. As obras selecionadas são de natureza diversa, envolvendo temas como a saúde mental indígena, o modo de vida de povos originários, o feminismo negro e descolonização epistemológica. Acreditamos que a expressividade do movimento indígena na Colômbia tenha relação com o volume de obras encontradas.

\section{Gráfico I. Localização geográfica das produções (2020)}

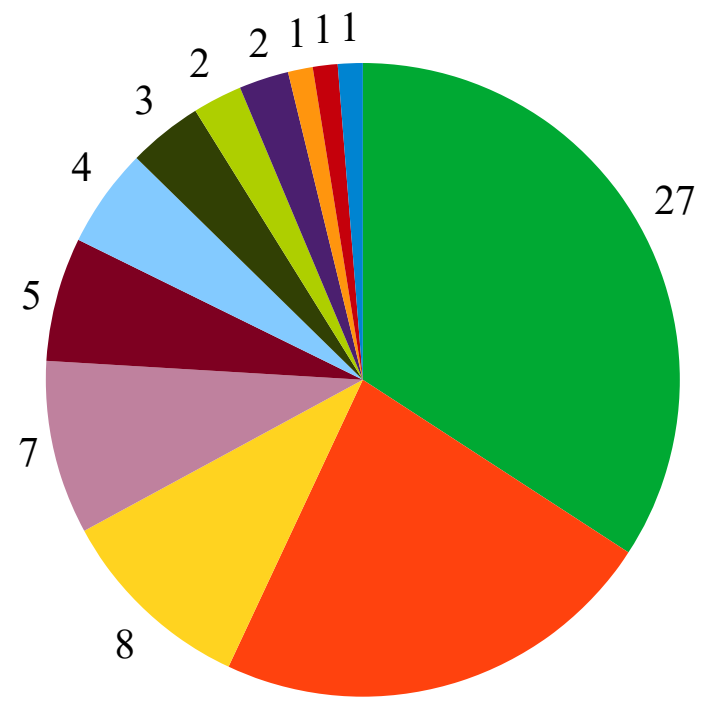

18
Brasil

Equador

Colômbia

Bolívia

- Chile

México

Argentina

Espanha

- Portugal

Inglaterra

- Peru

- Uruguai

Em relação ao tipo das obras, era esperado que a maioria estivesse na forma de artigos. Embora o número de teses, dissertações e monografias não seja tão expressivo, essas obras foram de grande valor dada a profundidade das pesquisas e a variedade de fontes e trabalhos etnográficos que as mesmas apresentaram.

Os vídeos selecionados vieram especificamente do Youtube, os demais bancos de dados que pesquisamos não possuíam material audiovisual que respondesse aos nossos critérios de busca. Logo, os vídeos selecionados correspondem a uma outra combinação de critérios, incluindo número de visualizações, origem e relevância do tema para o campo psi. Essa flexibilidade para adaptar critérios é característica da revisão de escopo (ADAMS et al., 2016). 


\section{Gráfico II. Tipo de Obra (2020)}

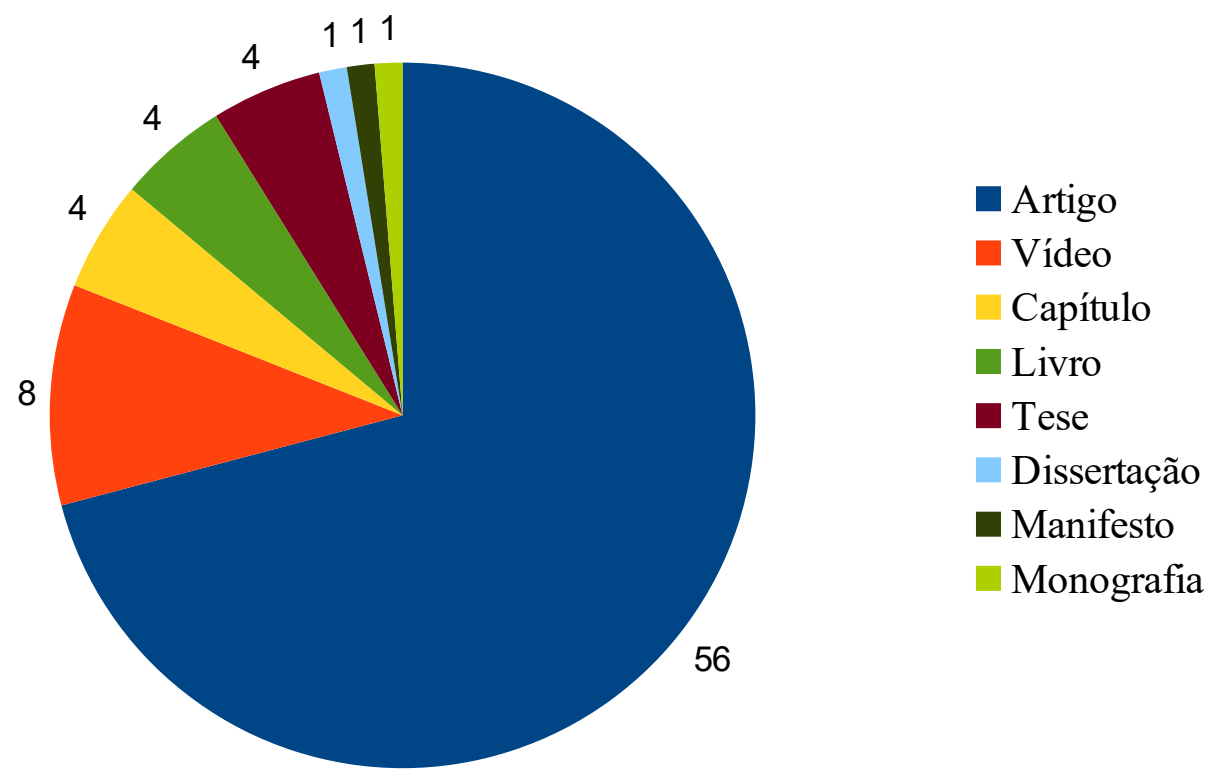

\subsection{Distribuição das publicações}

Foi encontrada baixa concentração de obras nas mesmas publicações. O destaque neste quesito é para o Conselho Regional de Psicologia de São Paulo (CRP-SP), que publicou em 2016 um livro que abordava o bem viver dos povos indígenas no Brasil. Note-se que em 2010 o CRP-SP já havia publicada o livro "Psicologia e Povos Indígenas", demonstrando o comprometimento com este tema.

O portal da Biblioteca Digital de Teses e Dissertações da USP contém três das obras selecionadas, as quais representaram contribuições de grande valor para esta pesquisa, sobretudo pelo valor das etnografias junto a comunidades Guarani (SILVA PRESTES, 2018; SOUSA; 2018) e a articulação do tema com o feminismo negro (PRESTES, 2018).

A Revista Polis, de Santiago do Chile, teve em duas de suas publicações três artigos selecionados. Em 2015 a revista publicou um número específico, cujo título "Buen vivir : ¿alternativa postcapitalista?”, foi inteiramente dedicado ao tema, contudo somente dois artigos se encaixaram em nossos critérios. Quatro outras revistas científicas publicaram dois artigos selecionados cada uma, sendo que essas também o fizeram na ocasião de edições especiais sobre noções de bem viver. O gráfico III mostra a distribuição das publicações 
conforme o periódico. Optamos por não listar no gráfico as publicações com uma única obra selecionada, esta informação está disponível no apêndice B.

\section{Gráfico III. Distribuição das publicações (2019)}

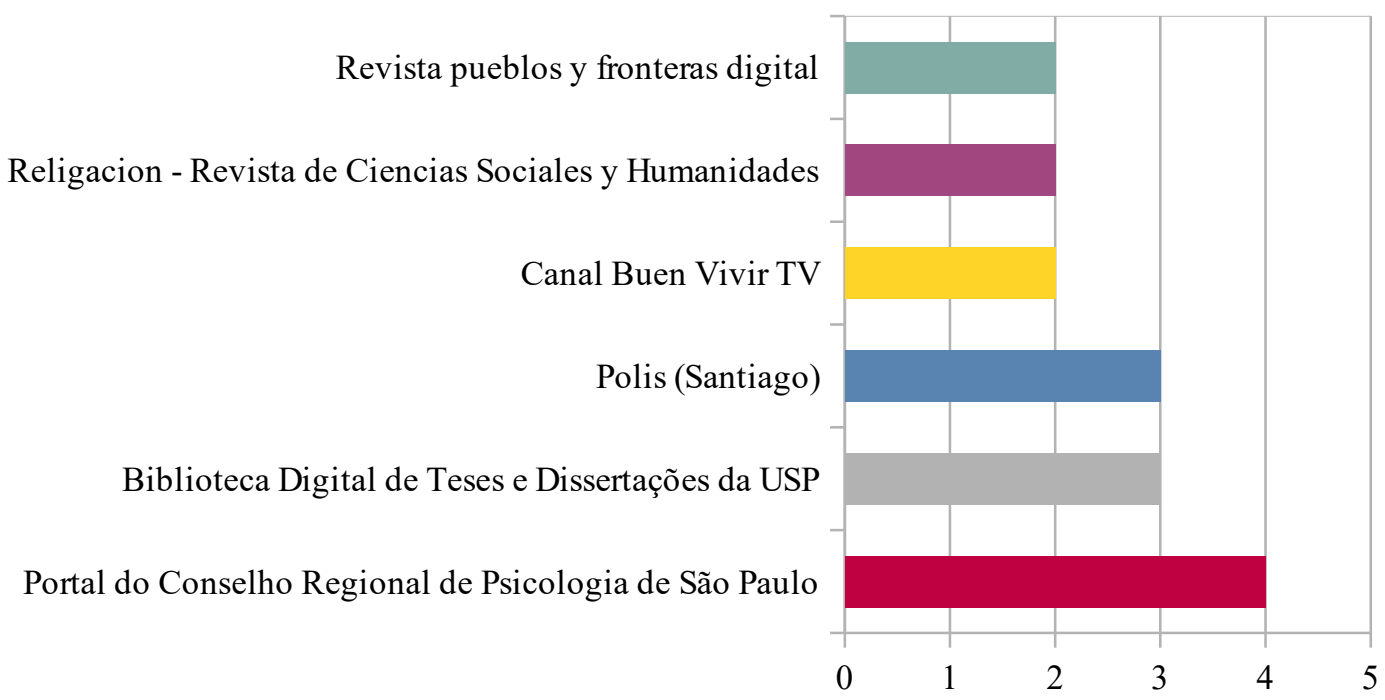

Sobre a disposição temporal das obras, lembramos que o período de busca foi de Janeiro de 2000 até Abril de 2020. A primeira obra que se encaixa em nossa combinação de critérios foi publicada em 2008, trata-se da Tese de Doutorado de Fábio O. N. da Silva (2008), "Elementos de etnografia Mbya: lideranças e grupos familiares na aldeia Tekoá Pyaú (Jaraguá-São Paulo).

Salientamos que em 2008 e 2009 aconteceram as mudanças nas Constituições do Equador e da Bolívia, nessa ordem. Estes direcionamentos políticos trouxeram notoriedade para as discussões sobre as noções de bem viver, e, por conseguinte, nota-se que as obras relacionadas ao campo psi começaram a aumentar.

Houve um pico de produções entre 2014 e 2018. A partir de 2019 o número já é bem menor. Acreditamos que a diminuição no volume de obras esteja relacionada com as quedas de Rafael Correa e Evo Morales, e a força contrária de outros movimentos políticos, sobretudo os de tendência neoliberal, bem como todos os problemas ligados à ascensão de uma direita conservadora na América do Sul.

Nesta onda retrógrada, citamos o exemplo do atual presidente brasileiro (no poder desde 2019), sem partido, que foi denunciado ao Tribunal Penal Internacional, de Haia, por incitação ao genocídio de indígenas brasileiros. Militantes vinculados à Comissão Arns e ao Cole- 
tivo de Advocacia em Direitos Humanos (Cadhu) alegam que "o mandatário tem enfraquecido as instituições de controle e fiscalização, demitido pesquisadores e foi flagrantemente omisso na resposta aos crimes ambientais na Amazônia" (EL PAÍ́S, 2019).

Também em 2019, assistiu-se ao triste episódio da militarização e toque de recolher em Quito, pelo governo de Lenín Moreno, contra manifestações de organizações indígenas, note-se que uma das primeiras iniciativas de Moreno foi extinguir a Secretaria del Buen Vivir. No mesmo ano, a Bolívia sofreu o golpe de Estado para destituição de Evo Morales, "o mandato do presidente foi interrompido, o procedimento foi inconstitucional (não houve destituição parlamentar, e sim renúncia forçada por uma 'sugestão') e as forças armadas foram as que definiram o desenlace" (MALAMUD, 2019), configurando os três elementos característicos de um golpe de Estado.

Esses são apenas alguns exemplos da ascensão de direitas conservadoras, neoliberais, na América do Sul. Nos últimos anos, o cenário político do continente tem sofrido com estratégias neoliberais que objetivam perpetuar o capitalismo extrativista e a concentração máxima de renda nas mãos de poucos. A diminuição na produção de obras sobre noções de bem viver parece refletir as quedas de movimentos políticos de esquerda.

\section{Gráfico IV. Publicações por ano (2020)}

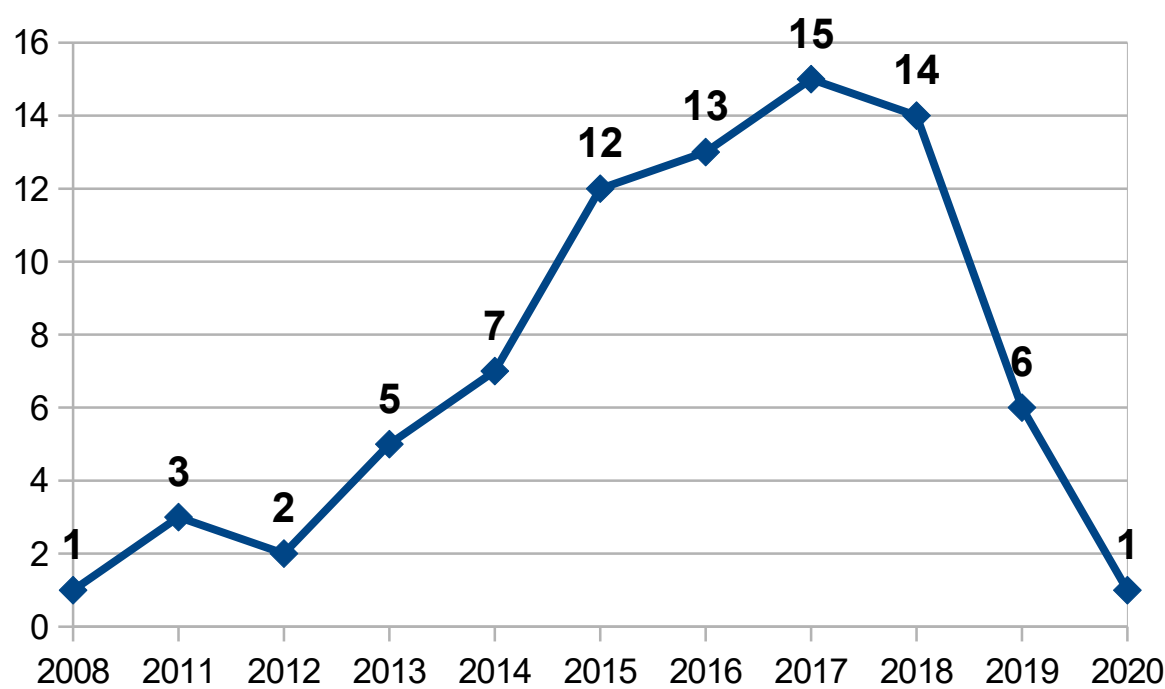




\subsection{Frequência de temas relacionados às noções de bem viver}

Identificamos durante a análise das obras temas frequentemente abordados em relação às noções de bem viver. A categorização foi criada de acordo com a frequência com que aparecem e a ênfase com que são discutidos nas obras.

Capturamos os temas mais frequentes e registramos a presença destes temas em cada uma das obras. Cada obra apresentou um ou mais dos temas listados, portando o gráfico reflete a incidência registrada dos temas. Os temas são detalhados na seção "Relato dos resultados", compondo a narrativa dos dados analisados.

\section{Gráfico IV. Distribuição dos temas (2019)}

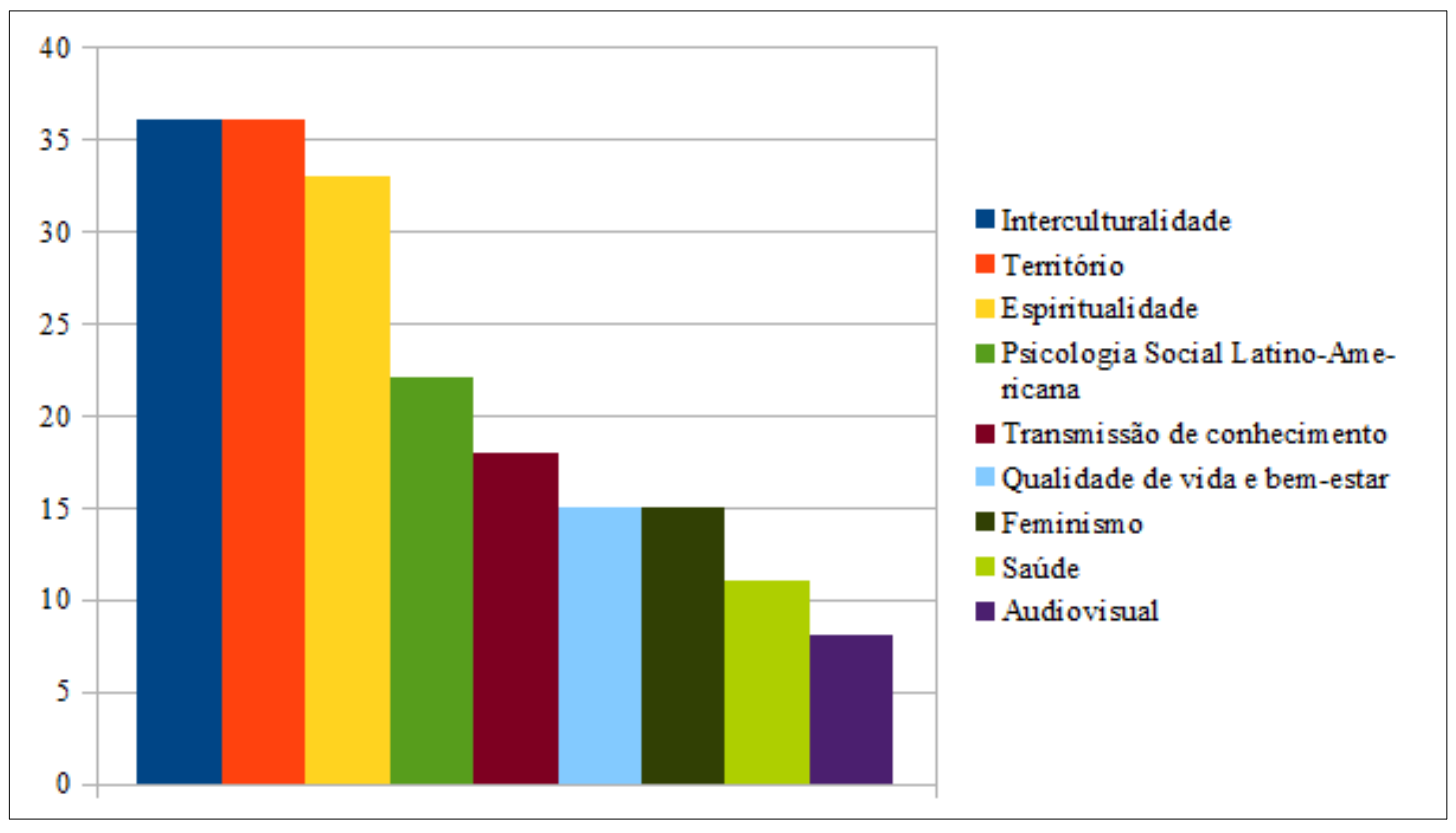

\subsection{Discussão dos resultados}

A discussão das obras selecionadas é apresentada abaixo na forma de uma análise temática. Esta construção temática é usada para fornecer uma visão geral da amplitude da produção (ARKSEY; O’MALLEY, 2005), ou seja, para apresentar uma narrativa da produção existente.

O texto abaixo foi organizado em subtópicos de acordo com os temas que mais se destacaram nas obras selecionadas: psicologia social latino-americana, qualidade de vida; interculturalidade, transmissão de conhecimento, território, espiritualidade, saúde e 
feminismo. Adicionamos uma análise das obras audiovisuais ao final da sequência de temas.

\subsubsection{Psicologia Social Latino-Americana}

As noções de bem viver e as reverberações sociopolíticas geradas por movimentos que empregam essas noções ainda não aparecem com frequência nas obras do campo psi. As obras encontradas dentro dos critérios da presente pesquisa estão relacionadas às abordagens mais críticas da psicologia social latino-americana, notadamente da psicologia comunitária, psicologia política e psicologia da libertação.

Maritza Montero, uma das principais expoentes da psicologia social comunitária, argumenta que a reconstrução crítica da psicologia social demanda um processo interdisciplinar contínuo a partir da perspectiva das maiorias pobres e oprimidas, e da crítica de ideias individualizantes da psicologia ocidental eurocêntrica (2012). A autora aponta que no presente contexto mundial de injustiça social extrema as noções andinas e amazônicas de bem viver, assim como conceitos da colonialidade do ser e movimentos de decrescimento do sistema produtivo, representam fontes e inovações importantes para direcionar o avanço da psicologia social latino-americana na crítica de opressões, exclusões e colonialidade (MONTERO et al., 2017, p. 150).

No âmbito das noções de bem viver, a autora argumenta que dentre as características fundamentais de projetos de intervenção participativa está o compromisso com a cultura das pessoas para as quais e com as quais se desenvolvem as ações sociais (MONTERO, 2012). O desenvolvimento participativo de ações sociais gera uma episteme baseada na relação com o outro, ou seja, o encontro de conhecimentos científicos e populares que se atualizam mutualmente e se unem para produzir outros novos, permitindo o fortalecimento de todos os agentes participantes. Logo, a compreensão do que é bem viver para cada comunidade, ou grupo beneficiário de uma intervenção, é parte essencial na prática de uma psicologia comprometida.

Montero (2012) argumenta que se busca intervir para transformar, incorporando os possíveis beneficiários da ação transformadora, convertendo assim a intervenção em um exercício de democracia participativa, afetividade e sensibilidade. A transformação social requer a participação de todas as pessoas envolvidas no fenômeno investigado, assim como requer a compreensão da cadeia de ações e do contexto político, histórico, social e econômico do fenômeno. 
Como exemplo de intervenção participativa no âmbito do bem viver, Montero (2012) analisa o projeto Allin Kawsay (bem viver) de terapia popular comunitária, desenvolvido por Silvia Fischer e Jean Bouquet (2008) em comunidades andinas quechua no Perú. Tomando como base princípios da educação popular de Paulo Freire (1968) e da psicologia comunitária, Fischer e Bouquet, ambos europeus, aprenderam o idioma quechua e viveram com os habitantes durante anos, aprendendo sobre suas vidas e desenvolvendo em parceria com as pessoas das comunidades uma metologia a partir da práxis.

Dentre os resultados de 25 anos de trabalho em parceria com povos quechua, Fischer e Bouquet desenvolveram uma terapia popular comunitária visando a diminuição da violência cotidiana através da melhora da auto-estima e da elaboração de problemas vividos na infância. Os procedimentos desta terapia incorporam noções de bem viver do povo quechua andino do Perú e técnicas para aumentar a empatia, melhorar relações pessoais e prevenir a violência (FISCHER; BOUQUET, 2008). As pesquisadoras formaram centenas de facilitadores, os quais, por sua vez, formaram mais de 4.350 docentes da rede pública de ensino, em 24 regiões do país (FISCHER; BOUQUET, 2008).

Saforcada (2011) argumenta que os atores da psicologia comunitária em países da "Indoafroiberoamérica" (conceito utilizado para enfatizar a composição indígena e africana da Ibero-América) necessitam considerar e assimilar as reflexões e formas de vida e organização social que são abordadas nas novas constituições do Equador (2008) e da Bolívia (2009), pois elas abarcam aspectos das culturas e pensamentos dos povos indígenas de ambos os países, sendo que um dos conceitos inovadores e centrais é o bem viver para toda sociedade.

$\mathrm{Na}$ perspectiva da psicologia da libertação, Gallardo (2014) produziu um estudo a respeito do desenvolvimento de competências libertadoras para a realização do bem viver. Tais competências colocam em evidência a dialética entre o saber e o fazer, equilibram o crescimento individual com a organização comunitária, facilitam a libertação pessoal e a transformação social (MARTIN-BARÓ, 1982). As competências libertadoras podem ser encontradas entre as virtudes populares, as formas de expressão autênticas de um povo.

Destarte, Gallardo (2014) apurou que para a população em questão as competências libertadoras poderiam ser desenvolvidas por meio de elementos culturais expressados através do teatro, da pintura do circo e da comunicação comunitária. Com base em seu estudo, realizado com a colaboração de 58 adolescentes do Centro de Atención Integral en Salud para Jóvenes (CAISJ) do Distrito Metropolitano de Quito, a pesquisadora concluiu que as 
competências libertadoras facilitam uma diminuição significativa dos comportamentos suicidas e o incremento da resiliência entre os adolescentes. As noções de bem viver empregadas nesse estudo emanam da Constituição de 2008 do Equador. A autora empregou o bem viver como um horizonte de vida alegre, de boa convivência entre as pessoas e a natureza, em uma perspectiva que enaltece a cultura popular e promove a desalienação social e pessoal através de expressões artísticas (GALLARDO, 2014).

Rozas (2015) afirma que se deve enfatizar, através da psicologia comunitária, um tipo de transformação social voltada para a construção de outra epistemologia, que incorpore a interculturalidade, a plurinacionalidade, os direitos coletivos e o bem viver. Para o autor a realidade dos povos originários na América Latina é construída com base em acordos que são realizados em uma dada comunidade, através de um processo interativo com outras comunidades, para que o produto emergente seja principalmente uma construção coletiva, assim como as noções de bem viver. Essas narrativas coletivas de bem viver não compactuam com o projeto desenvolvimentista da modernidade, mas com outras referências, outros quadros, os quais apresentam concepções distintas de mundo, trabalho, propriedade, educação, família, comércio, tempo, sociedade. Tais narrativas se originam de cosmovisões que consideram outros modos de vida, como as noções de bem viver no caso da Bolívia e do Equador (ARTARAZ; CALESTANI, 2013; ASCARRUNZ, 2013; CAAL, 2014).

Empregando a perspectiva da psicologia comunitária, Grondona-Opazo (2016) apresenta resultados de uma investigação sobre políticas sociais do Estado Equatoriano e de sua coerência com os postulados do bem viver, os quais davam forma ao projeto político da sociedade equatoriana no período de 2012 a 2013. O autor analisou divergências entre o que o Estado executou e as impressões relatadas por amostras populacionais, recolhidas durante três grupos focais.

Grondona-Opazo (2016) estabeleceu uma estratégia de análise baseada em necessidades comunicadas por representantes de comunidades impactadas por ações específicas do Estado. Sua estratégia incorporou a avaliação de ações de prevenção e desenvolvimento comunitário. Foram analisados três âmbitos fundamentais: o do mercado de trabalho e do consumo, da cidadania e dos vínculos sociais. Os resultados do estudo ressaltam a importância de separar as abordagens políticas de bem viver das noções encontradas entre os povos indígenas, pois há necessidades e reivindicações específicas que se dissipam quando demandas de povos indígenas são simplesmente "mescladas" às dos povos ocidentalizados. 
Finalmente, o autor afirma que para a realização de um sumak kawsay é necessário transitar de um enfoque centrado na inclusão social (visão do Estado sobre as necessidades da população em geral), para uma promoção de coesão social (visões de comunidades, com necessidades específicas, atendidas pelo Estado).

Em 2016, o Conselho Regional de Psicologia de São Paulo publicou o livro "Povos Indígenas e Psicologia: a Procura do Bem Viver". A obra dividida em duas partes apresenta, primeiramente, textos de dez intelectuais indígenas de diversas áreas do conhecimento e de diferentes etnias, discorrendo sobre a situação de suas comunidades, a interação com profissionais da psicologia e suas lutas pelo que consideram um bem viver. A segunda parte da obra, apresenta reflexões de catorze profissionais da psicologia, incluindo temas como interculturalidade, o diálogo das práticas psicológicas com os saberes de diferentes povos indígenas, violência estrutural e violação dos direitos indígenas e saúde mental indígena (CONSELHO REGIONAL DE PSICOLOGIA DE SÃO PAULO, 2016).

As reflexões de psicólogos nessa obra são pautadas, sobretudo, nos marcos teóricos da psicologia cultural, psicologia social comunitária e na psicologia da libertação. As reflexões atestam um compromisso ético-político para promover o bem viver dos povos originários, de acordo com suas cosmovisões e na riqueza de sua heterogeneidade, através de uma psicologia crítica e comprometida com a justiça social, tomando como centralidade a condição das populações indígenas no Brasil (TEIXEIRA, 2016).

Discute-se a construção da subjetividade do povo brasileiro através das marcas de um processo colonizador fundado no extermínio e escravização de povos indígenas e de povos negros originários de África. Esta história de violência, de exploração, de genocídios e epistemicídios, vive nas relações cotidianas, afetos, sofrimentos, medos, utopias e desejos da sociedade brasileira (TEIXEIRA, 2016). Para pensar a psicologia brasileira, esses representantes do CRP-SP apostam na reinvenção de teorias, de novas perspectivas de análise da dimensão subjetiva e referências de atuação profissional em psicologia que considerem a formação sócio-histórica do país, que dialoguem com cosmovisões dos diferentes povos que compõem esta sociedade (TEIXEIRA, 2016). As noções de bem viver, discutidas por representantes de diversos povos originários, estabelecem pontes entre as sociedades indígenas e não indígenas, pautando diálogos entre as culturas e os saberes, no intuito de construir uma sociedade onde, eventualmente, todos possam realizar suas noções de bem viver. 
Em 2019, o Conselho Federal de Psicologia (CFP) lançou o caderno "Referências técnicas para atuação de psicólogas(os) com povos tradicionais", no qual as noções de bem viver são abordadas como elementos para impulsionar um "giro decolonial" na psicologia, no sentido de contemplar a pluralidade da vida humana. O caderno reflete sobre princípios e posturas ético-políticos e ontoepistemológicas para orientar a profissão junto aos povos e comunidades tradicionais, dentro das seguintes perspectivas: as cosmovisões e seus sistemas simbólicos; o território e a produção de subjetividades; práticas comunitárias e o entendimento das noções de bem viver enquanto alternativas decolonizadoras.

A proposta do CFP (2019) compreende o desenvolvimento de abordagens psicológicas mais sintonizadas com os modos de vida, a relação com o território e a luta por direitos dos povos e comunidades tradicionais no Brasil e na América Latina (p. 81):

Para tanto, reconhecer os limites dos conhecimentos da Psicologia para a atuação junto a esses povos passa ser um primeiro passo para refazê-la, ao encontro das tradições, conhecimentos e modos de viver dessas comunidades. Estes limites são apontados como possibilidades de invenção de práticas que tenham na justaposição e trânsito de saberes e métodos para construção de conhecimentos conjuntos, sem recair no risco de novos colonialismos.

Rozas (2018) argumenta que as noções de bem viver, em sua diversidade de fontes, se enquadram como horizonte alternativo de transformação social de grande potencial dentro da corrente latino-americana da psicologia da libertação. Enquanto "práxis de fissura antisistêmica" (Rozas, 2018), a psicologia da libertação deve orientar-se desde a perspectiva de movimentos populares, para encarar o fenômeno a investigar, como parte de um trabalho paralelo de involucramento com as lutas e demandas das maiorias oprimidas. Os múltiplos saberes milenários dos povos originários da América, que têm sido sistematicamente negados pela modernidade, conformam perspectivas significativas e enriquecedoras para toda a humanidade e muitos campos de estudo, assim é o caso da medicina tradicional, da justiça comunitária, das noções de pachamama e das noções de bem viver (VIERA, 2013).

As obras comentadas nesta seção (SAFORCADA, 2011; VIERA 2013; GALLARDO, 2014; CARO \& VARAS, 2015; GRONDONA-OPAZO, 2016; MONTERO, 2016; ROZAS, 2018) formam uma narrativa sobre a desconstrução de ideais de felicidade associados ao poder de consumo e ao individualismo, bem como das abordagens adaptacionistas da psicologia ocidental eurocêntrica. O adaptacionismo é discutido com frequência como um tipo de doutrinação da pessoa ao sistema capitalista, enquanto as psicologias sociais latinoamericanas (acima discutidas), em geral, visam o fortalecimento das classes oprimidas pelo 
sistema capitalista, nos termos de questionamentos sociopolítico-econômicos da realidade e das opressões.

Como discutido anteriormente, a psicologia social latino-americana, a partir dos anos 80, foi fortemente influenciada pela psicologia da libertação de Martin-Baró (1986). Essa influência transparece nas obras analisadas, no compromisso ético e político com as populações oprimidas, bem como, na oposição ao individualismo e hedonismo característicos das psicologias ocidentais eurocêntricas.

Outras duas influências destacam-se nas obras selecionadas neste subcapítulo: a pedagogia de Paulo Freire e a sociologia da libertação de Fals Borda. Freire e Fals Borda construíram contundentes críticas ao colonialismo e à colonialidade no plano do pensamento científico e filosófico, valorizando memórias coletivas de movimentos de resistência. De um ponto de vista freiriano, as práticas psicológicas para terem sentido e serem efetivas, precisam estar ligadas às situações de vida dos grupos oprimidos e à sua realidade regional, nacional e transnacional, bem como a seus projetos de reconstrução social. Dentre as contribuições inspiradas na obra de Fals Borda, a ação participativa apareceu com frequência, sobretudo no sentido de facilitação social, no papel da psicologia como ciência de promoção do bem-estar coletivo, através do reconhecimento e fortalecimento das competências libertadoras características de cada comunidade.

Estas vozes da psicologia social latino-americana se apresentam como profissionais progressistas, democráticos, críticos, que desenvolvem estratégias de trabalho que possibilitam aos oprimidos revelarem sua situação de opressão e se engajarem na luta pela transformação.

A promoção de diálogos interculturais no campo da psicologia visa um alinhamento na busca de uma consciência crítica através do profundo questionamento das realidades sociais, situado em uma perspectiva histórica, nas lutas contra a força do colonialismo que se faz presente no patriarcado, no racismo, no latifúndio, na invasão cultural, na violência. Em suma, as obras selecionadas destacam o caráter eminentemente político da psicologia social latinoamericana.

\subsubsection{Qualidade de vida e bem-estar}

Lutas sociais, em grande parte, representam tentativas de equilibrar bem-estar individual e social, ou, como veiculado em noções de bem viver, a busca de equilíbrio entre 
os seres humanos e o todo do qual fazem parte. Essa busca por equilíbrio pode ser designada como bem viver, qualidade de vida ou felicidade. Seja qual for o termo utilizado, a operacionalização de constructos é a base para pesquisas quantitativas no campo da psicologia.

No contexto das discussões sobre bem viver, há possibilidades para a descolonização do campo psi nas novas formas de elaborar constructos e propósitos de intervenções. Como discutido anteriormente nas obras que tangem, principalmente, a psicologia comunitária (SAFORCADA, 2011; CARO \& VARAS, 2015; ROZAS, 2015; GRONDONA-OPAZO, 2016), a definição de objetivos de intervenções e políticas sociais devem ser processos protagonizados pelas próprias comunidades e a partir de suas cosmovisões, o mesmo pode ser aplicado para os âmbitos individuais do trabalho psicológico.

O estudo de Loria (2012) apresenta uma abordagem da psicologia da saúde em relação à qualidade de vida de populações em situação de vulnerabilidade social. A autora contrasta noções de qualidade de vida centradas na individualidade com noções inspiradas na coletividade. Segundo a autora, a qualidade de vida nos moldes capitalista-individualista é um grau de satisfação, um sentimento de bem-estar pessoal, relacionado com indicadores objetivos biológicos, psicológicos, comportamentais e sociais. Em outras palavras, uma autoavaliação, de acordo com critérios próprios, do estado físico, emocional e social em um determinado momento. Por outro lado, noções de bem viver priorizam a convivência salutar, seja ela entre os seres ou o equilíbrio das tensões entre os seres e o seu espaço de vida.

Para operacionalizar determinada noção de bem viver, Loria (2012) argumenta que soluções para a saúde devem ser pensadas "com" e a partir do coletivo e envolvendo o espaço de vida das pessoas, portanto, ela aborda a questão da vulnerabilidade social em termos dos riscos físicos e psicológicos relacionados com o tema ambiental, hábitos de alimentação e estilos de vida. A partir desta visão ela apresenta estratégias para promover o bem viver de mulheres com câncer na Bolívia, dentro e fora de instituições hospitalares.

Tais estratégias de bem viver são apresentadas no estudo de Loria (2012) através de dois programas específicos para pessoas em situação de vulnerabilidade social e seu entorno. O primeiro programa é orientado a sensibilizar a comunidade e equipes de saúde sobre a condição de paciente em tratamento não como pessoa ou população em situação de vulnerabilidade, mas pelo seu potencial de ação, visando melhorar sua qualidade de vida dentro e fora das instituições hospitalares. Essa abordagem de potência de ação enfatiza que a 
vulnerabilidade física e/ou psicológica não é necessariamente sinônimo de perda de capacidades e habilidades.

O segundo programa é dirigido aos cuidados de pacientes terminais e suas famílias, em cada uma das fases da aparição da enfermidade. Ambos os programas compreendem encontros entre pacientes, familiares e equipes de saúde com facilitadores adequadamente treinados na promoção de qualidade de vida das pacientes, dentro das premissas de um bem viver coletivo.

Artaraz e Calestani (2013) apresentam uma análise da noção de "bem-estar no texto constitucional boliviano" de 2009, em contraste com noções eurocêntricas de bem-estar. As autoras argumentam que, nas últimas duas décadas, intensificaram-se os debates sobre o significado do bem-estar, a imprecisão das definições correntes e os limites para a realização de um bem-estar imposto pelos atuais modelos de desenvolvimento. Elas alegam que as noções eurocêntricas de bem-estar tendem a fracionar a sociedade em indivíduos, além de ignorar, em grande parte, a relação entre as pessoas e os territórios. Argumenta-se que tais discussões refletem a crise civilizatória associada às limitações do modo de produção capitalista e das formas neoliberais de desenvolvimento (ARTARAZ; CALESTANI, 2013).

No contexto da assistência social, por exemplo, a motivação ideológica (neoliberal) desta forma altamente individualizada de bem-estar pode servir de justificativa para desinvestimentos na rede de assistência social por parte do Estado, pois, cada indivíduo seria responsável pelo seu bem-estar, definido frequentemente como felicidade (ARTARAZ; CALESTANI, 2013).

As autoras afirmam que as noções de bem viver, inspiradas em cosmovisões andinas e amazônicas, incorporadas nas constituições da Bolívia e Equador demonstram possibilidades de "refundação" nacional através do resgate e incorporação de noções de bem-estar dos povos indígenas. Tais noções apresentam possibilidades de operacionalizar ações de bem-estar que valorizem tanto as relações humanas interculturais quanto as relações entre seres humanos e território, ou seja, noções de boa convivência (suma qamaña em aimara), abarcando uma visão de sustentabilidade que é ignorada pelas noções de bem-estar eurocêntricas (ARTARAZ; CALESTANI, 2013).

Artaraz e Calestani (2013) mencionam que o artigo $8^{\circ}$ da atual Constituição boliviana apresenta o suma qamaña como "um dos princípios ético-morais mais importantes de uma sociedade plural" (p. 18). O conceito vigora também no artigo $80^{\circ}$, o capítulo sobre educação, 
no qual se coloca ênfase em uma educação que reforce o conhecimento e a prática da proteção do meio ambiente, da biodiversidade e do território. No capítulo sobre economia, o artigo $313^{\circ}$ apresenta metas que articulam o suma qamaña para a eliminação da pobreza e da exclusão social, a redistribuição da riqueza e a redução das desigualdades. Finalmente as autoras concluem que no caso da Bolívia registraram-se avanços no plano teórico, contudo a operacionalização em práticas e ações carece de exemplos concretos.

Xavier Albó, jesuíta, antropólogo e sociolinguista, é um indigenista com extenso trabalho na disseminação das ideias de suma qamaña na Bolívia. Albó (2011) discute possibilidades e a pertinência de ferramentas para mensurar o bem-estar numa perspectiva do bem viver, ou seja, sobre como medir o avanço de determinada comunidade na realização de seu bem viver, a partir de elementos da cosmovisão de tal comunidade.

Primeiramente, o autor destaca que o bem viver não pode ser medido simplesmente pelo acesso a certos bens materiais quantificáveis. Uma quantificação econômica também não é suficiente, embora possa ser essencial incluir ambos os aspectos quando o ponto de partida é uma situação de privação que ameaça a própria sobrevivência (ALBÓ, 2011). No sentido primário de garantir a sobrevivência plena, instrumentos internacionais para medir a superação da pobreza básica, como o índice de Necessidades Básicas Insatisfeitas (NBI) ou os índices de vulnerabilidade, podem servir de base para medir essa condição inicial que é sobreviver; a partir daí, pode-se avançar para pensar o bem viver ou o bom conviver

O "Índice de Desenvolvimento Humano" (IDH), atualmente empregado pela ONU, é uma medida resumida de desenvolvimento humano em três dimensões básicas: renda, educação e saúde. Segundo Albó (2011), talvez o IDH tenha ficado aquém do "humano", porque não chega ao ponto de entrar nas características que são "mais propriamente humanas", como os laços sociais e a relação com um território. Seus indicadores referem-se apenas a indivíduos, independentemente de saberem se relacionar com os demais. É um índice centrado em viver e crescer como indivíduo.

Outros dois aspectos fundamentais a serem mensurados segundo Albó (2011) são a "qualidade das relações sociais" e a "qualidade das relações com a natureza" (p. 143). O autor alega que o primeiro aspecto poderia incluir alguns dos índices de governança desenvolvidos pelo Programa das Nações Unidas para o Desenvolvimento (PNUD), particularmente aqueles que aparecem no subíndice de participação e no subíndice de estabilidade política. No segundo, alguns indicadores associados ao desenvolvimento sustentável também podem 
entrar, e outros que já estão sendo desenvolvidos no âmbito do que a Constituição 2008 do Equador designou "Direitos da Natureza” (ALBÓ, 2011).

Por outro lado, o autor argumenta que em relação aos aspectos mais afetivos da convivência, é inviável pensar em indicadores universais. Abordagens mais qualitativas terão que ser projetadas para cada realidade social e cultural. Como ponto de partida, o autor sugere que dentro de cada comunidade ou cultura os valores mais apreciados pelos povos que a vivem sejam identificados e explicitados. A partir desses valores, algumas relações desejáveis de coexistência poderiam ser mapeadas, permitindo assim avaliar quando são cumpridas ou violadas.

Aprofundando a discussão de índices, constructos psicológicos e escalas no âmbito intercultural, apresentamos o artigo de García-Quero e Guardiola (2017) sobre correlações entre "índices de pobreza e qualidade de vida percebida" em uma região rural do Equador. Utilizando dados coletados de 977 famílias, os pesquisadores analisaram traços culturais e ideológicos para a compreensão de qualidade de vida a partir das prioridades e das noções de bem viver das pessoas dessa comunidade.

García-Quero e Guardiola (2017) criaram uma linha de "Escassez de Bem-Estar Subjetivo" e compararam com duas linhas compostas por índices de pobreza. Como esperado, os autores apontam que famílias com renda muito baixa têm maior probabilidade de reportar índices baixos de "bem-estar subjetivo". Contudo, famílias de renda muito baixa que produzem uma parte dos alimentos que necessitam e vivem em comunidades indígenas têm probabilidade significativamente menor de reportar índices baixos de "bem-estar subjetivo". Os autores afirmam que, para essas comunidades, rendas muito baixas não estão diretamente correlacionadas com menores índices de bem-estar, e argumentam que esse contraste pode ser explicado por componentes de sua noção de bem viver, como sentimento de pertença a um grupo e a um território, solidariedade e capacidade de produção de alimentos para consumo próprio (GARCÍA-QUERO; GUARDIOLA, 2017).

Os componentes da noção de bem viver acima mencionados são corroborados com resultados da investigação de Andrea Delgado (2018) com um grupo de 42 mulheres quechua, vendedoras de têxteis em um centro comercial de Chinchero, no Perú. Em seu estudo Delgado (2018) empregou a "Escala de Cantril" como medida objetiva, e realizou entrevistas semiestruturadas e observações etnográficas. A pesquisadora aponta que, além dos itens acima mencionados, a partilha de alimentos e rituais de celebração aparecem com frequência nas 
falas relacionadas ao bem viver dessas mulheres. Segundo a autora: "ao compartilhar suas colheitas com a comunidade, as famílias diversificam sua dieta e ao mesmo tempo fortalecem seus laços comunitários em eventos sociais para celebrar casamentos e aniversários" (DELGADO, 2018, p. 49).

$\mathrm{Na}$ sequência, discutimos o desenvolvimento de uma escala desenvolvida especificamente para medir o bem-estar do povo andino lickan-antay, dentro de "limites geopolítico-sociais específicos" (GÚTIERREZ-CARMONA et al., 2019).

Gútierrez-Carmona et al. (2019) desenharam e validaram um instrumento específico para medir o bem-estar do povo lickan-antay (andino) do Chile, combinando elementos presentes em noções de bem viver de povos andinos do Equador e da Bolívia e padrões ocidentais de mensuração de qualidade de vida (baseados em teorias hedônicas e eudaimônicas de bem-estar).

O povo lickan-antay, que se organiza em torno de uma lógica social comunitária, habita o deserto do Atacama, o mais árido do mundo. Seu complexo sistema de vida em proximidade com a natureza tem sofrido imensamente com o crescimento do turismo de larga escala e pela instalação de mineradoras transnacionais. Segundo os autores, embora as noções de bem viver ainda não estejam refletidas em projetos políticos no Chile, a literatura relacionada aponta similaridades entre o modo de viver desse povo e as noções de bem viver de outros povos andinos, notadamente dimensões relacionadas com fatores comunitários e do equilíbrio das tensões entre os seres e o seu espaço de vida.

Como resultado, os autores apresentaram uma escala de 51 itens, agrupados em "dimensões de harmonia": interna, comunitária, com a natureza, social e de desenvolvimento étnico cultural lickan-antay. Os autores argumentam que essa escala permite obter dados culturalmente representativos, pois foi criada com a ajuda da comunidade e a partir de uma compreensão da identidade cultural e da cosmovisão lickan-antay, em parceria com lideranças e outros membros da comunidade (GÚTIERREZ-CARMONA et al., 2019, p. 66).

O constructo "bem-estar subjetivo" (BES), amplamente empregado nas psicologias ocidentais eurocêntricas, tem se popularizado a partir da demanda de grandes organizações mundiais por parâmetros, ferramentas e escalas de qualidade de vida que possam ser mais abrangentes que a mera relação de renda com a percepção de qualidade de vida (ONU, 2014). Como o próprio nome informa, trata-se de um constructo que permite aferir a percepção individual de satisfação com a vida, uma acepção pessoal de bem-estar. As noções de bem 
viver trazem o aspecto do coletivo para essas discussões, além de questionar as próprias acepções hegemônicas de qualidade de vida.

Discutir noções de qualidade de vida a partir de cosmovisões dos povos indígenas das Américas inclui questionar interpretações de bem-estar pessoal, ou coletivo, que envolvem exclusivamente o acesso a bens materiais, expandindo esses critérios para abranger questões religiosas, territoriais, de pertencimento, de migração, de preservação de saberes ancestrais entre outras de natureza cultural e coletiva.

\subsubsection{Interculturalidade}

A cultura é um dos pilares da discussão do bem viver, contudo não nos ateremos a uma conceitualização específica de cultura, pois consideramos de maior relevância para o presente estudo a investigação de um tema que aparece na grande maioria das obras selecionadas nesta revisão, a interculturalidade.

De acordo com Catherine Walsh (2014), a Confederação de Nacionalidades Indígenas do Equador (CONAIE) promove a interculturalidade como um dos princípios de seu projeto político desde 1990 (p. 20). Em contraste com o multiculturalismo do ocidente, a CONAIE define a interculturalidade como um processo, uma prática e um projeto político de transformação estrutural e institucional fundamental, que inclui a transformação radical do Estado. Walsh (2014) define interculturalidade como:

herramienta pedagógica que cuestiona de manera contínua la racialización, subalternización, inferiorización y sus patrones de poder, visibiliza maneras distintas de ser, vivir y saber, y busca el desarrollo y creación de comprensiones y condiciones que no sólo articulan y hacen dialogar las diferencias en un marco de legitimidad, dignidad, igualdad, equidad y respeto, sino que también - y a la vez - alientan la creación de modos outros de pensar, ser, estar, aprender, enseñar, soñar y vivir que cruzan fronteras.

Logo, a interculturalidade significa mais do que relacionalidade horizontal entre culturas, ela representa a composição de um projeto de sociedade diferente da atual, de uma prática política alternativa à geopolítica hegemônica (monocultural e monorracial), de construção de conhecimento e de distribuição de poder baseadas no intercambio cultural em termos equitativos, em condições de igualdade. Tal projeto de sociedade inclui o que Sousa Santos (2012) define como diálogos interculturais, os quais devem partir do pressuposto da incompletude de cada cultura envolvida, enquanto "universos de sentido" regidos por sistemas lógicos distintos. $\mathrm{O}$ autor aponta que as sociedades que consideram a "incompletude da pluralidade de culturas que a compõe" estão buscando soluções para atender demandas de 
seus diferentes grupos étnico-raciais, como no caso das novas Constituições da Bolívia e do Equador (SOUSA SANTOS, 2016; ALCANTARA; SAMPAIO, 2017)

Há mais de uma década, Boaventura Sousa Santos tem incluído em sua produção literária discussões sobre noções de bem viver latino-americanas, abordando frequentemente o tema interculturalidade. Ademais, entre 2010 e 2012 o estudioso dirigiu um amplo projeto de investigação denominado "Justiça indígena, plurinacionalidade e interculturalidade. Análise comparativa entre Equador e Bolívia", projeto que surgiu para analisar as transformações constitucionais que influenciaram a vida social, política e cultural de ambos os países no século XXI (SOUSA SANTOS, 2016).

Dentre as tendências mais relevantes para o campo psi, o autor tem discutido a interculturalidade como uma via de acesso à dignidade humana, a partir da premissa que "temos o direito a ser iguais quando a diferença nos inferioriza, temos o direito a ser diferentes quando a igualdade nos descaracteriza" (SOUSA SANTOS, 2016, p. 42). O estudioso frisa a importância do conhecimento dos povos indígenas, das epistemologias do Sul, tanto para o resgate da dignidade humana quanto para a continuidade da vida no planeta, sugerindo que "a defesa da interculturalidade e dos direitos humanos é cada vez mais a mesma luta" (SOUSA SANTOS, 2016, p. 38).

No prisma do bem viver, o autor apresenta como exemplo concreto de diálogo intercultural os direitos da natureza refletidos na Constituição do Equador de 2008. Sousa Santos (2016) argumenta que tal fato gerou uma entidade intercultural ao associar noções oriundas de cosmovisões indígenas com a ideia de direitos humanos, unindo "humanidade e natureza" (p. 40), uma inovação para lutar contra a profunda crise ecológica de nossos tempos. Sobretudo, através da crítica do caráter capitalista da ciência ocidental moderna, o qual descreve como a "mercantilização global da vida através de dois não bens de consumo, o trabalho e a natureza" (SOUSA SANTOS, 2016, p. 107).

De acordo com o autor, a interculturalidade significa para além do reconhecimento da diversidade, a celebração da diversidade cultural e o enriquecimento recíproco entre culturas. Por exemplo, a interculturalidade plurinacional mencionada na atual Constituição da Bolívia abrange dimensões culturais, políticas, territoriais e econômicas da diversidade, ou seja, o reconhecimento constitucional de que há várias formas, todas igualmente legítimas, de organizar a ação política, conceber a propriedade, administrar o território e organizar a vida econômica (CABRALES SALAZAR, 2015; MATO, 2016; SOUSA SANTOS, 2016). 
Sousa Santos (2016) argumenta que a dificuldade em reconhecer e valorizar a diversidade intercultural se chama colonialismo, de acordo com o autor, "o colonialismo é todo sistema de naturalização das relações de dominação e de subordinação baseado em diferenças étnicas ou raciais" (p. 20), neste sentido o Estado moderno é monocultural e colonial. Na Bolívia há um Vice Ministério de Descolonização e no Equador, durante a gestão de Rafel Correa, o Estado manteve serviços de descolonização do Estado (encerrados na gestão seguinte).

O Vice Ministério de Descolonização (VMD) da Bolívia foi fundado a partir da aplicação da Constitución Política del Estado Plurinacional de Bolivia de 2009, cujo artigo 09 declara como função essencial do Estado descolonizar e eliminar a discriminação. Dentro deste marco, foi criada a Lei 45 "Contra el racismo y toda forma de discriminación", os atores chave para que ela fosse criada foram os povos indígenas, comunidades afro bolivianas, trabalhadores, movimentos feministas, coletivos LGBT entre outros (CAMARGO, 2014). De acordo com a Declaração de Durban, emitida pela ONU (2001) como resultado da "Terceira Conferência Mundial contra o Racismo, a Discriminação Racial, a Xenofobia e Formas Correlatas de Intolerância", a erradicação do racismo e da discriminação é essencial para que se possa iniciar a descolonização de uma sociedade.

Sobre as ações, políticas públicas e ferramentas utilizadas pelo VMD para fomentar a participação e o respeito aos povos e nações indígenas na sociedade e no governo, destaca-se a aplicação da Lei 45, a difusão de materiais educativos (cartilhas), o acompanhamento e a atuação legislativa, a revisão educacional histórica e filosófica, a promoção de rituais sagrados ancestrais, a declaração do dia 12 de Outubro como "Dia da Descolonização".

De acordo com Camargo (2014) ações educativas são consideradas prioritárias pelo VMD, objetiva-se através da educação infantil o reestabelecimento dos conhecimentos ancestrais, com a revalorização das culturas pelo fortalecimento de alguns nichos, como idioma, história e espiritualidade. No âmbito institucional, o VMD preconiza a interculturalidade através de mudanças na estrutura e função de partes do Estado, como a criação de cursos e palestras para promover a participação das nações e povos "indígena originário campesinos" (EQUADOR, 2008), comunidades interculturais e afro bolivianas na Administração Pública do Estado Plurinacional, bem como a autonomia e a valorização de tais comunidades, por exemplo, através da oficialização de governos autônomos indígenas assegurada pela Constituição equatoriana (EQUADOR, 2008). 
A Professora e pesquisadora de história indígena Graciela Chamorro tem como escopo de pesquisa a religião, a língua e a história dos povos falantes de Guarani, que habitam não só o Brasil, mas também o Paraguai, a Bolívia, a Argentina e o Uruguai (CHAMORRO, 2011). A produção de Chamorro sobre os povos Guarani possibilita uma comparação com os pontos de vista acima discutidos, pois os últimos se concentram em noções oriundas, principalmente, de povos Aymara e Quechuas.

De acordo com Chamorro (2011), "mais que simplesmente viver bem, bem-viver, trata-se, fundamentalmente, de conviver bem, viver bem em comunidade" (p. 3). Segundo a autora, a metáfora do bem viver nas sociedades não indígenas e os debates que vem gerando estão relacionados com as noções acadêmicas de interculturalidade e descolonização. A autora aponta que ao assumir outras cosmovisões, outros universos de sentido, a interculturalidade anda junto com a "descolonização dos saberes, da natureza e, também, de colonizados e colonizadores" (p. 04). Como exemplo de interculturalidade a autora menciona que princípios ético-morais de ñandereko (vida harmoniosa) e teko kavi (vida buena), de matriz guarani, estão refletidos na Constituição boliviana de 2009 (p. 01):

Un Estado basado en el respeto e igualdad entre todos, con principios de soberanía, dignidad, complementariedad, solidaridad, armonía y equidad en la distribución y redistribución del producto social, donde predomine la búsqueda del vivir bien.

Portanto, a interculturalidade, nos termos descritos acima, é um plano de fundo que tem amparado grande parte das obras e discussões envolvendo noções de bem viver latinoamericanas. Como apontado por Walsh (2014), a interculturalidade é uma ferramenta pedagógica que fomenta novos projetos civilizatórios, sobretudo, novas formas de sociabilidade centradas em diálogos culturais, nos quais as partes reconhecem os limites, a incompletude, e as potências das culturas envolvidas.

\subsubsection{Transmissão de conhecimento}

Outro tema frequente nas obras selecionadas é a transmissão de conhecimentos. A discussão sobre a importância da interculturalidade, enquanto ferramenta pedagógica que questiona a colonialidade e seus padrões de poder, continua nessa temática, em relação direta com a necessidade de promover as epistemologias do sul global e o questionamento das premissas e estruturas meritocráticas eurocêntricas que prevalecem nas instituições públicas de ensino na América Latina. 
Dentre as obras analisadas encontram-se reflexões sobre a transmissão de conhecimento em âmbitos muito diversos, desde a transmissão oral de conhecimentos sobre os modos de viver (e bem viver) de comunidades indígenas até inovações em sistemas públicos de educação na América do Sul. Há também relatos de experiências educacionais inovadoras, inspiradas em novos paradigmas educacionais, e discussões sobre o presente e o futuro da educação nos estados que incorporam as noções de bem viver em suas políticas.

Caro e Varas (2015) discutem a relação entre noções de bem viver e educação a partir da intervenção psicossocial comunitária. Nessa perspectiva, as autoras relataram uma experiência de intervenção psicossocial e comunitária realizada num espaço de educação não formal chamado "Escuelita Intercultural para el Buen Vivir" (EIBV), mantido por um coletivo de trabalhadoras da área social de Antofagasta, Chile. O principal objetivo foi o de contribuir para a reflexão sobre os princípios orientadores dentro da intervenção psicossocial no campo da educação comunitária, e simultaneamente, analisar o seu potencial como modelo ou matriz de trabalho em infância, interculturalidade e bem viver. As autoras relataram a importância de incorporar aspectos de descolonização do ser o do saber através da valorização dos saberes dos povos indígenas, incluindo noções de bem viver em um diálogo intercultural. Como resultado da intervenção psicossocial as autoras sistematizaram os procedimentos e as ferramentas desenvolvidas na Escuelita, visando à continuidade, o fortalecimento e a replicação do bem viver comunitário e da transformação social através da participação infantil.

No Brasil, Stumpf e Bergamaschi (2016) apresentam reflexões sobre diálogos interculturais na construção da escola específica, diferenciada e intercultural para o povo Mbya, a partir de convivências realizadas em aldeias Mbya no Rio Grande do Sul. As autoras relatam que a partir do início do século XXI observou-se um processo de ampliação de escolas Mbya Guarani, em que coletivos indígenas foram se apropriando da instituição, bem como reivindicando o acesso a conhecimentos e tecnologias da cultura ocidental, com objetivos de fortalecer sua autonomia e avançar na conquista de direitos. Na construção de tal escola, a espiritualidade, a afetividade, a sensibilidade, o simbolismo e a arte que fazem parte do teko porã do povo Mbya auxiliam nos processos de interação com as tecnologias e conhecimentos de outras culturas. As autoras apontam que a trajetória da escola Guarani Mbya evidencia uma trajetória de apropriação da instituição escolar pela comunidade, possibilitando a construção de projetos pedagógicos interculturais. 
Ampliando a discussão de projetos pedagógicos interculturais, Fabiane Silva Prestes (2018) ratifica a importância da incorporação das cosmovisões indígenas para se pensar novos modelos educacionais, a partir de colaborações junto a comunidades Kaingang no Sul do Brasil. A pesquisadora aponta que a educação ocorre naturalmente no cotidiano dessas comunidades, é parte "do entrelaçamento entre coletividade, ancestralidade, natureza e arte" (p. 192). Assim, a pesquisadora relata que a educação é parte indissociável da noção de bem viver Kaingang (kanhgág há kar), "ela se materializa no dia a dia, no diálogo, no ensinamento da cultura e na prática conjunta do artesanato. A valorização e respeito pelos mais velhos também" (SILVA PRESTES; 2018, p. 228).

Corroborando com esta visão, Pedro Luiz Macena (2016), liderança Mbya Guarani da aldeia Tekoa Pyau, educador e coordenador cultural do Centro de Educação e Cultura Indígena da Terra Indígena Jaraguá, SP, argumenta que a integração do conhecimento indígena e não indígena é essencial para a realização do bem viver em sua comunidade, haja vista os problemas da convivência com a sociedade não indígena. $\mathrm{O}$ educador pontua que o conhecimento não indígena hoje é fundamental para que as comunidades indígenas possam lutar pelos seus direitos, pelos seus territórios.

Através de uma pesquisa que coloca em diálogo elementos de culturas Guarani e de culturas Africanas, Noguera e Barreto (2018) discutem sobre o conceito de infância e as dinâmicas das ações do cotidiano escolar. Os autores apresentam reflexões sobre o conceito de infancialização como possibilidade de rompimento com as práticas atuais de experimentação da realidade, a partir do que consideram "orientações filosóficas africanas e indígenas". Os autores propõem que através de vivências baseadas numa ética afroperspectivista e da articulação entre princípios de ubuntu e teko porã na escola, crianças, adolescentes, adultos e idosos podem manter conexões equilibradas com os demais seres com os quais convivem, se reaproximando daquilo que "os torna seres biocêntricos, curiosos e criativos: a infância, como uma cumplicidade cosmológica com o existir" (NOGUERA; BARRETO, 2018, p. 625).

Essa aproximação entre seres humanos e os demais seres vivos também é encontrada na obra de Burgos Ayala (2016). Em artigo teórico, a autora tece uma crítica ao desequilíbrio entre humanos e todos os outros seres da natureza causado pelo atual modelo de desenvolvimento econômico. A autora afirma que uma alternativa para corrigir tal situação é através da integração de práticas de bem viver, notadamente através da combinação dos 
direitos da natureza (respeito, proteção e restauração) com direitos humanos de educação e participação. A autora argumenta que instituições educativas são cenários de impacto social que podem formar novas gerações de cidadãos, com consciência ecológica mais aprimorada, através da articulação de variáveis e dimensões do bem viver, sobretudo a compreensão do bem viver através da natureza, na busca de equilíbrio entre os sistemas político, social, cultural e natural.

Há duas obras que aprofundam a discussão entre psicologia, pedagogia e as noções de bem viver. Sanchez Cabezas, Gonzalez Valarezo e Zumba Vera (2016) discutem a reestruturação do papel das psicólogas educativas no Equador a partir do Plano Nacional do Bem Viver 2013 - 2017. Através de pesquisas, entrevistas e grupos focais com psicólogas educativas as pesquisadoras sistematizaram e validaram posições teóricas para embasar uma prática revigorada a luz de noções de bem viver.

As pesquisadoras apontam que os novos compromissos desta profissão incluem ampliar a participação popular na transformação social, de modo que a orientação de intervenções psicoeducativas convertam-se em recurso para empoderar os membros das diferentes comunidades na luta por uma sociedade mais igualitária e multicultural. Deve-se promover a criação de propostas e metas que respondam às necessidades específicas de cada comunidade, respeitando e incorporando suas cosmovisões (SANCHEZ CABEZAS; GONZALEZ VALAREZO; ZUMBA VERA, 2016).

Enfatizando o potencial da interculturalidade, presente nas noções de bem viver, para o âmbito pedagógico, o psicólogo brasileiro Edinaldo Rodrigues (do povo Xukuru do Ororubá) ressalta que, no campo da educação, a "psicologia pode oferecer sua contribuição como ciência que estuda as relações do homem em sociedade" (2016, p. 230) e, portanto, pode ajudar a pensar propostas educacionais que promovam o diálogo equilibrado entre culturas de forma a respeitar e incorporar fontes diversas de conhecimento em projetos pedagógicos interculturais.

Dentre os marcos de amplo alcance que o governo de Alianza Pais $(2007$ - 2017) estabeleceu no âmbito da educação, no ano de 2015, a Secretaria de Educação Superior, Ciência, Tecnologia e Inovação (SENESCYT) do Equador disponibilizou ao Sistema de Ensino Superior o documento "Construyendo Igualdad en la Educación Superior. Fundamentación y lineamientos para transversalizar los ejes de igualdad y ambiente" (Magdalena Herdoiza, 2015). Segundo Magdalena Herdoiza (2015), responsável técnica da 
obra, a publicação tem como foco a interculturalidade, visando sua incorporação prática em todos os campos do conhecimento, com itinerários acadêmicos que incluam a criação de disciplinas e cursos específicos.

Aprofundando este debate sobre as transformações no ensino equatoriano, em função das noções de bem viver incorporadas à Constituição de 2008, Madroñero e colegas (2020) discutem mudanças na política educativa do Equador e das consequentes ações governamentais, durante os mandatos de Rafael Correa (2007 a 2017). Os autores sugerem que as noções de bem viver articuladas pelo Estado equatoriano promovem a superação da política educativa tradicional eurocêntrica do país. O estudo apresenta, entre outras evidências, a criação das quatro Universidades Emblemáticas do Equador em 2013. Elas foram criadas, durante o segundo mandato de Rafael Correa, visando a transformação do sistema educativo, com a intenção de trazer inovações científicas, culturais e pedagógicas que possibilitassem métodos transdisciplinares e interculturais, visando a soberania de pensamento a partir da diversidade de cosmovisões e epistemes do Sul, com base em princípios de sumak kawsay enquanto "conceito polilógico e dialógico" (p. 245).

Finalmente, Piedrahita (2020) analisou o sistema educacional colombiano sob uma perspectiva pedagógica pautada em noções de bem viver, a qual denominou "pedagogía del buen vivir" (p. 57), profundamente inspirada na obra de Paulo Freire. Empregando elementos de noções de bem viver andinas e amazônicas (como o bom conviver, a interculturalidade e relações de equilíbrio com o território) o pesquisador construiu uma matriz para analisar os pressupostos vigentes no cenário educacional e pedagógico colombiano.

O pesquisador concluiu que os postulados do bem viver e das pedagogias decoloniais ainda não foram profundamente incorporadas ao sistema educativo colombiano, salvo casos específicos liderados, sobretudo, por movimentos sociais, em processos comunitários com limitado número de pessoas. De acordo com sua análise, o modelo educativo que prevalece na nas instituições colombianas ainda preconiza a formação de mão de obra especializada, o desenvolvimento de competências técnicas e noções de cidadania amplamente eurocêntricas. Portanto, o pesquisador afirma que a transformação do sistema educacional colombiano deve envolver mais do que currículos escolares com temas indígenas, sendo essencial a construção de métodos e teorias de aprendizagem "a partir da lógica e do paradigma de cada comunidade" (PIEDRAHITA RODRÍGUEZ, 2020, p. 63).

O conjunto das obras analisadas nesta seção sinaliza um abismo entre noções de 
transmissão de conhecimento das sociedades não indígenas e indígenas latino-americanas. Uma parte das obras analisadas reflete sobre o sentido e a prática da transmissão de conhecimentos em comunidades indígenas e das diferentes abordagens de integração dos conhecimentos e práticas educacionais "não indígenas". Enquanto outra parte das obras discorre sobre a transformação do modelo tradicional de ensino nas sociedades não indígenas.

A discussão sobre formas de transmissão de conhecimento sobre o bem viver abrange o questionamento das próprias noções de educação e ensino de forma geral, da dinâmica de todos os elementos humanos e não humanos envolvidos, dos projetos civilizatórios e das formas de sociabilidade. Nota-se que a América Latina tem pensado a sua própria renovação educativa e pedagógica em um diálogo com as epistemologias marginalizadas pelo ocidente.

A interculturalidade é um tema central nesta discussão, efeito esperado tendo em vista que, em sua maioria, as noções de bem viver promovem uma abordagem de diálogo entre culturas, de encontro onde seja possível construir novos saberes através de respeito mútuo e uma postura crítica baseada na realidade das maiorias oprimidas da América Latina, na encruzilhada de marcadores sociais, como raça-etnia, gênero e classe.

As discussões presentes nas obras analisadas, sobre o modelo de ensino chamado tradicional (meritocrático, eurocêntrico) evidenciam, a partir de um perspectivismo latinoamericano, que não há passividade na propagação e manutenção desse modelo, pelo contrário, o campo educacional reflete a implacabilidade da massificação cultural perpetrada pela globalização.

O pensamento de uma educação libertadora, a partir de Paulo Freire, por exemplo, abre espaço para construções de modelos pedagógicos pertinentes para cada realidade, considerando a especificidade de cada povo. Experiências inovadoras de compartilhamento de conhecimento junto a comunidades índigenas têm experimentado sucesso à medida que passam a considerar aspectos essenciais de seus cotidianos, de seus modos de bem viver, como a espiritualidade, a afetividade, a sensibilidade e a arte.

\subsubsection{Território}

A quase totalidade das obras que abordam noções de bem viver latino-americanas focalizam, de alguma forma, a relação dos seres vivos com o espaço onde vivem, principalmente a relação com um território. Para construir a narrativa desta seção, selecionamos as obras que se aprofundaram na discussão sobre relações entre comunidades e 
territórios.

Com frequência, as ideias de território e natureza são utilizadas nessas obras de maneira similar, como espaço de vida ou ambiente. Porém, a ideia de "natureza" pode estar associada a uma abordagem dualística, na qual os "seres humanos" são referidos como separados daquilo que se considera "natureza", a dicotomia sujeito/objeto. Por outro lado, a abordagem monística, anti-essencialista (MONTERO, 2002), compreende a realidade como uma construção cotidiana das pessoas, e, portanto, as pessoas são parte deste todo, seja ele "natureza indivisível" ou realidade. Esclarecemos que para tecer a narrativa dos resultados encontrados nesta pesquisa empregamos a abordagem monística, amparados na perspectiva da psicologia social comunitária (MONTERO, 2002).

As obras analisadas que se referem a povos indígenas no Brasil (SILVA, 2008; CHAMORRO, 2011; AGUIAR; PEREIRA, 2012; MELIÁ, 2015; CRP-SP, 2016; BEZERRA FIGUEIREDO, 2017; NOGUERA; BARRETO, 2018; SOUSA, 2018; SIQUEIRA; SANTOS, 2018) apontam a centralidade do território para realização de um bem viver, sobretudo a constante tensão enfrentada por esses povos frente a invasão recorrente de suas terras.

Violências vividas pela negação de direitos sobre o território têm sido discutidas com frequência no campo psi, sobretudo, como "efeitos biopsicossociais" (SILVA, 2008; CRP-SP, 2016; SOUSA, 2018; SIQUEIRA; SANTOS, 2018) relacionados com impedimentos a realização do bem viver em um território, expropriação de terras indígenas, crimes ecológicos, a impossibilidade de livre trânsito, tendo em vista que migrações sazonais fazem parte dos modos de vida e hábitos alimentares ancestrais de povos indígenas.

Outras populações do continente também articulam o seu bem viver em relação ao território, como é o caso discutido por Mina Rojas et al. (2015) que retrata o modo de viver e de se relacionar com o território de comunidades negras do Sul da Colômbia, na região de La Toma. O estudo aborda a mobilização de mulheres negras como protagonistas na defesa de seus territórios e na busca pelo bem viver, baseando-se em saberes ancestrais transmitidos oralmente. A fala de Francia Márquez, representante legal do Conselho Comunitário de La Toma, ilustra essa relação (p. 168)

Todo esto que hemos vivido ha sido por el amor que hemos conocido en nuestros territorios, el amor de ver germinar una palma de plátano, de un día soleado de pesca, de sentir cerca a la familia, defender nuestra permanencia y alli donde hemos crecido y no queremos salir porque esa tierra de las abuelas y los abuelos, puede ser también la tierra para nuestras nietas y nuestros nietos, nuestra tierra es nuestro lugar para soñar con dignidad nuestro futuro. 
Ao relatar as resistências históricas e intergeneracionais dessas mulheres, as autoras apontaram colaborações entre comunidades negras lideradas por mulheres, indígenas e campesinas na defesa do território contra grandes mineradoras e em defesa do rio Ovejas. Nas comunidades em questão existe o ditado que "o rio Ovejas é pai e mãe" (MINA ROJAS et al., 2015, p. 169), expressão que evidencia a relação de unidade entre pessoas e território. A questão do enraizamento, o sentimento de pertencer a um lugar específico, é um exemplo de constructo psicológico utilizado pelas autoras ao discorrerem sobre a relação dessas mulheres com seu território, relação que envolve ancestralidade, espiritualidade, sentimento de pertença e saúde física e mental.

Por sua vez, Carrasco e Ramirez (2015) destacam no título de sua obra a relação entre bem viver e território, "Somos un pueblo, precisamos un territorio porque allí es donde se da la vida indígena; sin territorio no hay identidad como pueblo. Buen vivir en Argentina". As autoras salientam que embora um termo equivalente ao bem viver não tenha sido encontrado, os princípios fundamentais que marcam as reivindicações das nações indígenas pesquisadas na Argentina se assemelham aos elementos que têm sido discutido como componentes de noções do bem viver em movimentos sociais na Bolívia e no Equador: subjetividade, interculturalidade, território e comunitarismo.

No caso da Bolívia, noções de bem viver estão conectadas de forma inseparável ao movimento indígena e à reivindicação de territórios desde a década de 1970 que culminou na formação de partidos políticos indígenas e de organizações não governamentais, bem como na confederação campesina (ARTARAZ; CALESTANI, 2013). A atual Constituição boliviana (2009) garante a delimitação de territórios indígenas autônomos no país, onde se assegura aos grupos indígenas o direito a exercer o autogoverno de acordo com instituições que reflitam suas formas de organização política, econômica, social e judicial (ARTARAZ; CALESTANI, 2013, p. 110).

El significado del término «territorio» es clave para entender el buen vivir hasta ahora como la manera en que se integran todos los aspectos de recursos ambientales (tierra, agua, recursos forestales) y la relación que tienen con el medio ambiente los grupos indígenas, de tal manera que su misma reproducción cultural y existencia están ligadas a su territorio.

Diana Oliveros Fortiche (2017) apresenta em seu estudo impressões sobre o pensamento e a experiência do povo indígena Yukpa (etnia composta por aproximadamente 4.700 pessoas), em Serranía del Perijá na Colômbia, em torno da constituição de seu Plano de Vida, no qual o território figura como eixo central da existência desse povo. A criação do 
Plano de Vida desse grupo iniciou-se há vários anos, quando foi realizado, pelo Conselho Indígena Yukpa em colaboração com a Organização Nacional Indígena de Colômbia, um dos primeiros diagnósticos que buscava compreender sua situação social, política, territorial, produtiva e cultural. O plano procura criar condições para a realização do kshenano, uma noção de bem-estar geral, articulada no texto como similar às demandas de bem viver dos movimentos indígenas do Equador e da Bolívia. Em seu estudo a autora utilizou o método de sua pesquisa foi da pesquisa-ação participante (IAP). As conclusões mostram a centralidade da noção de bem viver (kshenano) para a organização comunitária deste grupo e a relevância do território como base fundamental de sua identidade, existência e movimentos migratórios vitais.

Ana Paula Massadar Morel (2019) apresenta um estudo sobre a relação entre território, bem viver e saúde presente no movimento zapatista na região de Alto Chiapas no México. A autonomia do movimento zapatista transparece nas diferentes dimensões da vida coletiva e na sua relação com o território. A concepção de saúde deste grupo é diretamente relacionada com a noção de território, na qual entende-se que para ter saúde é preciso pertencer a um cosmos, permeado pelo respeito recíproco entre os mais diferentes seres, em uma luta constante para engrandecer o ch'ulel (espírito) e, com isso, caminhar rumo ao lekil kuxlejal, a noção de bem viver desta comunidade (MOREL, 2019).

A pesquisadora relata que a noção de lekil kuxlejal é um conceito cultural tzotzil que envolve certas práticas e formas de entender, criar e recriar o mundo, numa relação de respeito entre os seres e destes com a terra, incluindo a consideração pelos ciclos vitais da terra, respeitando sua dimensão sagrada (MOREL, 2019). Para fortalecer o protagonismo da comunidade, os tzotzil buscam a recuperação dos seus saberes ancestrais a partir do diálogo com os mais velhos, identificando modos de valorizar a relação com a terra, visando a realização de sua noção de bem viver, o que inclui a boa saúde de todos na comunidade (MOREL, 2019).

Portanto, seja na Argentina, Bolívia, Brasil, Colômbia, Equador, México ou qualquer outro país da América Latina, a relação com o território é um ponto central em se tratando de noções de bem viver inspiradas nas cosmovisões dos povos locais. Logo, para a psicologia latino-americana uma série de constructos como enraizamento, pertença, saúde e sofrimento psicossocial podem ser considerados para pesquisa e intervenção através da relação entre comunidades e territórios. 
A invasão da América pelos europeus continua sendo fonte de sofrimento psicossocial aos povos indígenas, pois é a origem dos impedimentos relacionados ao acesso e uso dos territórios. O capitalismo, em suas múltiplas representações privadas e públicas, enquanto sistema extrativista e reificante continua consumindo, usurpando e destruindo territórios indígenas, ao passo que se mantém a negação de direitos ou a restrição a territórios habitados originalmente por estes povos.

As noções de bem viver veiculam a mensagem de que é necessário um território para se realizar o bem viver. Portanto, aos profissionais do campo psi é importante um posicionamento político nessa questão, pois enquanto ciência que se ocupa de saúde e bemestar é essencial apoiar a luta desses povos através de nossas escolhas e ações políticas.

Para o campo psi em geral, além do apoio às lutas pelos territórios indígenas e de povos tradicionais, muitos desdobramentos são possíveis em relação a territórios, mesmo nas sociedades não indígenas. Ao pensarmos o bem viver nas cidades, sobretudo nas metrópoles, muitos são os ângulos a serem percorridos, por exemplo, a relação de pessoas em comunidades urbanas com o seu espaço de vida.

\subsubsection{Espiritualidade}

Segundo Chamorro (2011), no caso dos Guarani, não existe, a rigor, o termo religião. Uma tradução aproximada encontra-se na expressão "nosso bom modo de ser (nande reko katu) que entre seus vários significados inclui a experiência religiosa" (p.3). A autora aponta que os sistemas de crença dos Guarani é algo essencial no pensamento e na expressão do grupo (teko). Ela argumenta que entre os Guarani atuais as expressões teko katu e sua variante teko porã são os marcadores constantes da "identidade do grupo diante da sociedade circundante" (p.10).

Os Guarani Kaiová e Pai-Tavyterã utilizam as expressões teko katu e teko porã para se referirem a seus bons costumes, às suas normas éticas tradicionais e ao sistema tradicional que orienta a vida dos seres divinos e divinizados (CHAMORRO, 2011). Os Guarani Mbyá identificam com essas expressões o modo de ser ideal dos que habitaram a "primeira terra", uma terra sem males, e estabelecem assim as regras que devem orientar a sua existência (SILVA, 2008; CHAMORRO, 2011; AGUIAR; PEREIRA, 2012; MELIÁ, 2015; CRP-SP, 2016; BEZERRA FIGUEIREDO, 2017; SOUSA, 2018; SIQUEIRA; SANTOS, 2018).

Segundo Meliá (2015) aspectos espirituais são parte importante do bem viver, do 
modo de ser (teko porã) Guarani, orientando suas noções de pertencimento e de reciprocidade, na experiência de vida comunitária. De acordo com o autor, o teko porã é formado por vários aspectos, dentre os quais se destaca o tekó marangatu (Meliá, 2015, p. 116)

Lugar privilegiado da palavra é o tekó marangatú, o modo de ser santo e religioso expressado mediante as palavras boas e verdadeiras dos mitos e dos relatos exemplares. Do tekó marangatú é parte essencial também o ritual na sua dupla dimensão do canto e da dança, linguagem envolvente ao qual participa toda a comunidade numa espiral ascendente até os de acima.

Silva (2008) apresenta dados etnográficos sobre aldeias Mbya Tekoá Ytu e Tekoá Pyaú, localizadas junto ao parque Estadual do Jaraguá, em São Paulo. Ele argumenta que o tekó (modo de ser) é parte central da cosmovisão Guarani Mbya, frequentemente articulado como "o comportamento esperado" em diversas situações. O pesquisador aponta que o tekó nem sempre é nominado nas falas, mas faz-se presente pelos elementos que o constituem, revelando pluralidade comportamental entre grupos e posições sociais. Dentre os componentes do tekó, o pesquisador destaca a definição de rituais cotidianos e a comunicação com as divindades, pois para os dois povos investigados "somente através da observação do tekó é possível transcender e transformar-se na pessoal ideal, que é a própria divindade” (p. 160).

Javier Lajo (2016) discorre sobre a Pachamama como a deidade que representa toda a natureza, a mãe Terra na cultura quechua cusquenha, e o equilíbrio da vida no planeta depende diretamente da ligação espiritual e do respeito a essa divindade. De forma similar, Kaká Werá (2019) afirma que a noção de bem viver do povo Guarani, de Krukutu, incorpora o sagrado na compreensão da existência, na visão de que todos formam parte de um organismo vivo, uma consciência viva que combina constantemente o passado e o futuro.

Como discutimos anteriormente, a espiritualidade é um aspecto central das sociedades latino-americanas, é presente nas tradições e rituais, está nos conhecimentos ancestrais, na oralidade de nossos povos, ou seja, é parte do cenário que antecede e propicia o debate do bem viver.

Noções de bem viver de povos indígenas da América apresentam, com frequência, noções de espiritualidade, ideias de transcendência do plano material para uma existência, de alguma forma, superior. Esta noção de transitoriedade, em direção a condições melhores, está alinhada com o legado da teologia da libertação, movimento científico religioso engajado em lutas contra a opressão e pela libertação dos povos. A psicologia da libertação e a psicologia 
social comunitária estão também associadas a este movimento de luta contra opressão e pela libertação dos povos, pois, ambas promovem a vida, a convivência equilibrada entre os seres. $\mathrm{Na}$ psicologia da libertação a intenção de liberar as grandes maiorias das estruturas de opressão está ancorada na potencialização das virtudes dos povos, tais como a fé e a esperança que emanam das espiritualidades das comunidades e povos da América Latina.

Logo, a discussão do bem viver no campo psi pode ser relacionada com outra tendência: os estudos que envolvem espiritualidade enquanto uma dimensão da qualidade de vida, a qual está associada à saúde física e mental, como apontado pelo Professor Geraldo José de Paiva (2004, p. 125)

O tema geral Espiritualidade e Qualidade de vida é de interesse para a Psicologia que, aqui como em outros casos, investigará na espiritualidade e na qualidade de vida o que há de psicológico, isto é, aquela faixa da realidade humana que não é puramente lógica nem biológica, mas exatamente psíquica

Portanto, é crucial que a psicologia enquanto ciência esteja apta a trabalhar com as diversas compreensões e manifestações de espiritualidade que embasam a relação dos povos com a realidade, com a transitoriedade da matéria e com o transcendental.

\subsubsection{Um outro paradigma de Saúde}

Outra tendência que emergiu em nossa análise são elaborações em torno de concepções de saúde. Muitos povos originários não possuem termos correspondentes a ideia de saúde ocidental (HERMIDA; 2011, MELIÁ, 2015; ROZAS, 2015; FIGUEIREDO, 2017; SOUSA, 2018; MOREL, 2019), logo, os debates sobre bem viver, situados no encontro entre culturas, apresentam abordagens para tratar o tema de forma intercultural, ou seja, considerando as especificidades de cada comunidade, suas necessidades e suas formas de agir no âmbito do que pode ser considerado saúde.

César Hermida (2011) argumenta que a Constituição de 2008 do Equador estabelece diretrizes para a construção de novos paradigmas de saúde, considerando, sobretudo, a diversidade de cosmovisões indígenas do país, sob os princípios da interculturalidade, equidade e bioética, conforme o Artigo $32^{\circ}$ (EQUADOR, 2008). O pesquisador aponta que, embora haja pouca correspondência direta entre noções de saúde ocidentais nas cosmovisões indígenas, as noções de bem viver, inspiradas em cosmovisões diversas, transcendem a visão limitada da saúde que separa corpo e alma. A abordagem da atual Constituição aplica um conceito holístico de saúde para indivíduos, grupos e sociedade, combinando corpo, alma, 
espiritualidade e território, visando a promoção integral da saúde, com foco em prevenção (HERMIDA, 2011).

Flaviana Rodrigues de Sousa (2018) discute em sua obra pontos de tensão no diálogo intercultural em torno das questões de saúde indígena, dando ênfase ao tema da saúde mental. De um lado a perspectiva ocidental, Estado e afins, do outro as perspectivas de povos indígenas, especialmente de grupos Guarani Mbya, a partir da noção de teko porã (bem viver). Dentre os resultados, destaca-se a importância central do território nas noções de saúde/doença para os povos estudados. A morada simbólica desses povos está em colapso e por isso há um grande sofrimento mental, ilustrado por dados epidemiológicos alarmantes quando comparados a população em geral: altos índices de suicídio e consumo prejudicial de álcool e outras drogas. A pesquisadora aponta que embora não haja objeto comum entre as duas perspectivas de saúde, existem pontos de articulação entre esses mundos, por exemplo: alimentação, corporeidade, práticas de prevenção e cura, religião, a força da palavra, a relação com os remédios da mata e a natureza, o respeito à sua tradição e ao conhecimento ocidental de saúde. Os povos originários vivenciam cosmologias próprias, o que exige direcionamentos pertinentes para cada grupo, para cada cosmovisão (SOUSA, 2018).

Gregóry Turra (2018), a partir de estudo feito em colaboração com a comunidade Mbya Guarani Tekoa Jata'ity, no Sul do Brasil, relata que embora não haja uma palavra que designe saúde em Guarani, as práticas voltadas para a produção da saúde e do contentamento no cotidiano também estão relacionadas com a realização do teko porã. O pesquisador relata que em muitos discursos estar alegre ou triste, por períodos prolongados, se assemelha a um entendimento de estado de saúde. Na comunidade em questão, um estado prolongado de tristeza, desânimo ou raiva pode ser interpretado como uma "doença, ora associada ao corpo, ora ao espiritual... quando se fala em saúde, doença aqui deve ser entendida em um sentido abrangente, capaz de abarcar um conjunto de processos ou eventos" (TURRA, 2018, p. 62).

Faz-se necessário operacionalizar práticas de promoção e cuidado no campo da saúde mental que considerem, por conseguinte, a pessoa em sua relação com determinada coletividade e seu território (SIQUEIRA; SANTOS, 2018). Ações do Ministério da Saúde brasileiro, embora ainda em processo de construção, chegaram a se orientar nessa direção. Por exemplo, o princípio geral de atenção à saúde mental indígena dos Distritos Sanitários Especiais Indígenas (MINISTÉRIO DA SAÚDE, 2014, p. 08) que inclui dimensões do teko porã para abordar questões de saúde destes povos: 
Contribuir para a potencialização dos projetos de bem viver das diferentes comunidades, famílias e indivíduos indígenas a partir de ações de promoção da saúde, prevenção e atenção a agravos relacionados à saúde mental, que compartilhem responsabilidades e ações com comunidades, profissionais de atenção primária e redes de apoio locais, incentivem o protagonismo indígena e a mobilização social valorizando e respeitando os saberes, modos de organização social, valores, economias e as tecnologias próprias de cada comunidade.

Edinaldo Rodrigues (2016), psicólogo de origem Xukuru do Ororubá de Pernambuco, aponta que, após anos de pesquisa e prática em diversas comunidades indígenas, é fundamental pensar a partir do coletivo para se discutir a saúde indígena, "técnica e política precisam caminhar juntas, ter um olhar diferenciado para concepções de saúde e doença e, principalmente, compromisso ético para apoiar e respeitar os saberes tradicionais, no diálogo com os pajés e outros detentores dos saberes indígenas no que diz respeito à saúde mental." (p. 234).

O psicólogo ressalta que, nas sociedades indígenas, com frequência, crises de saúde mental estão relacionadas à perda de vínculos culturais e questões identitárias, portanto, cuidados relativos à saúde indígena devem ser desenvolvidos "sob a lógica das especificidades culturais dos diferentes povos indígenas" (RODRIGUES, 2016, p. 236). O atendimento a essas populações deve ser integral, com propostas de atuação voltada para ações coletivas, "onde o conflito individual passa a ter um lugar na coletividade" (RODRIGUES, 2016, p. 237).

Conforme discutido nos dois subcapítulos anteriores, o território e a espiritualidade são aspectos fundamentais e indissociáveis das noções de bem viver, e, portanto, da saúde dos povos latino-americanos. O mesmo se aplica para a questão da coletividade, enquanto fator imprescindível para compreensão de questões de saúde nas sociedades indígenas.

Para o campo psi em geral, a perspectiva das noções de bem viver coloca ênfase na reflexão sobre a importância de pensar a saúde mental e física em um contexto amplo, no qual, para além das relações sociais, os fatores macropolíticos também influenciam. $\mathrm{Na}$ contramão das abordagens psicológicas adaptacionistas e hedônicas, pensar a saúde mental das maiorias oprimidas da América Latina requer pensar suas lutas por condições básicas de uma vida digna, e para tanto é necessário pensar como potencializar as forças das pessoas, ou grupos, através de seus saberes ancestrais, sua religiosidade, seus modos de existir em grupo, seus rituais, seus modos de resistir e de compartilhar. 


\subsubsection{Feminismo}

O emprego das noções de bem viver no âmbito das lutas e movimentos sociais liderados por mulheres, em vários países da América Latina, foi um tema frequentemente abordado nas obras selecionadas. Como relatado anteriormente, nosso primeiro contato com o tema foi através do feminismo negro brasileiro, especificamente a Marcha das Mulheres Negras 2015 Contra o Racismo e a Violência e pelo Bem Viver: o Bem Viver como Nova Utopia.

Nilma Bentes, uma das idealizadoras da Marcha das Mulheres Negras 2015 e uma das fundadoras do Centro de Estudos e Defesa do Negro do Pará (CEDENPA), articulou para que uma noção de bem viver fosse incorporada ao movimento da Marcha, segundo Nilma, "o bem viver foi incorporado para sinalizar que acreditamos na necessidade de mudança do chamado modelo de desenvolvimento, combatendo, portanto, a mercantilização-financeirização dos recursos naturais/bens comuns, o consumismo exacerbado, o lucro insano, o capitalismo neoliberal" (AMNB, 2015).

Logo, o conceito é apresentado no manifesto da Marcha como forma de construir coletivamente uma nova dinâmica de vida e ação política, por meio da superação do racismo, do sexismo e de todas as formas de discriminação. Justiça equidade, solidariedade e bem-estar constam como valores inegociáveis dentre as reivindicações do manifesto (AMNB, 2015). Salientamos que a Marcha das Mulheres Negras continua acontecendo anualmente em diversas cidades brasileiras, no dia 25 de Julho, Dia Internacional da Mulher Negra, latinoamericana e caribenha, mantendo o bem viver como horizonte de melhor organização social para todas (GELEDÉS, 2020).

Como já mencionado, em 2020, a "Marcha das Mulheres Negras de São Paulo" foi realizada de forma virtual, mas manteve o bem viver como parte de suas reivindicações, por resgatar formas ancestrais de gestão do coletivo e do individual e pelos princípios de solidariedade, reciprocidade, responsabilidade e integralidade (MARCHA DAS MULHERES NEGRAS DE SÃO PAULO, 2020).

A primeira Marcha das Mulheres Indígenas levou 2.500 representantes de mais de 130 povos às ruas de Brasília em Agosto de 2019, com o tema "Território: nosso corpo, nosso espírito", reivindicando demarcação de terras indígenas, fortalecimento da FUNAI (Fundação Nacional do Índio), não municipalização da SESAI (Secretaria Especial de Saúde Indígena), educação de qualidade em seus territórios e pelo bem viver (MARCHA DAS MULHERES 
INDÍGENAS, 2019). O documento final da mobilização traz uma série de reivindicações, entre as quais estão o da demarcação e proteção de todas as terras indígenas contra invasores e as propostas de abertura ao grande capital (MARCHA DAS MULHERES INDÍGENAS, 2019, p. 01):

Somos totalmente contrárias às narrativas, aos propósitos, e aos atos do atual governo, que vem deixando explícita sua intenção de extermínio dos povos indígenas, visando à invasão e exploração genocida dos nossos territórios pelo capital.

O documento que busca sintetizar as demandas de mais de 130 povos indígenas salienta a relação que existe entre os territórios tradicionais dos povos indígenas, seus corpos e sua vida espiritual.

Ainda no Brasil, a pesquisadora Clélia Prestes (2018) realizou sua pesquisa de doutorado em Psicologia Social na qual empregou a noção de bem viver articulada pela Marcha das Mulheres Negras de 2015. A pesquisadora investigou estratégias de compreensão e promoção da saúde de mulheres negras, pela perspectiva dos direitos humanos e do feminismo negro, utilizando a interseccionalidade como método de análise e de ação, orientada no sentido do bem viver. Nesse estudo, a noção de saúde pessoal está diretamente relacionada com a saúde do grupo de pertencimento e da natureza como um todo.

Combinando a interseccionalidade e bem viver a pesquisadora afirma ter atingido uma compreensão mais sofisticada da saúde, concebendo-a como o equilíbrio entre demandas e recursos, na encruzilhada entre aspectos pessoais (orgânicos, psíquicos, energéticos e interpessoais), coletivos, sociais, ecológicos e espirituais, no sentido da saúde integral (PRESTES, 2018). Segundo a pesquisadora, a interseccionalidade aponta que a concepção de saúde dessas mulheres tem relação direta com uma multidimensionalidade de forças, a partir de sua raça, gênero, classe, território, orientação sexual, capacidades físicas e mentais, entre outras (PRESTES, 2018).

Soledad Varea e Sofía Zaragocin organizaram, em 2017, o livro "Feminismo y Buen Vivir: Utopias Decoloniales", unindo trabalhos de oito pesquisadoras do tema. Há destaque para os debates de feminismos latino-americanos emergentes, como o feminismo comunitário, o feminismo descolonial e o feminismo negro. As pesquisadoras apontam que dentre as principais discussões na região estão as novas ordens de gênero baseadas em noções de bem viver, e os exercícios de repensar os feminismos comunitários e decoloniais existentes dentro de um bem viver, e não como algo concebido a partir do estado (VAREA; ZARAGOCIN, 
2017). As autoras apontam que as noções de bem viver no governo do Equador têm sido utilizadas, principalmente, em relação às noções de igualdade de gênero e na Bolívia no sentido de despatriarcalização e descolonização (VAREA; ZARAGOCIN, 2017).

Karen Silva e Tamires Garcia (2018) relacionam o ecofeminismo e o giro ecocêntrico presente na Constituição equatoriana de 2008 através de noções andinas de bem viver e os direitos da natureza presentes na Constituição do Equador (2008). Segundo as autoras, para a manutenção da vida na Terra o ecofeminismo propõe um olhar e um sentir mais próximos da natureza para que seja possível conhecer e respeitar os seus ciclos de regeneração e que propõe igualmente um observar e respeitar os ciclos do corpo da mulher (SILVA; GARCIA, 2018).

Também no Equador, Ivette Vallejo Real e Corinne Duhalde Ruiz (2019) investigaram como mulheres indígenas amazônicas têm se organizado para lutar contra injustiças, reivindicar direitos e resistir à destruição de seus territórios, sobretudo, contra as explorações de minérios e petróleo intensificadas durante os 10 anos de governo de Rafael Correa, e continuadas por Lenin Moreno.

As pesquisadoras relatam que em 2013 mulheres lideranças dos povos shiwiar, kichwa, sapara, waorani e shuar organizaram um primeiro encontro de mulheres de organizações indígenas amazônicas pela defesa de suas vidas, territórios e pelo bem viver. A partir desse encontro, três marchas e audiências presidenciais foram realizadas com agendas e demandas documentadas junto ao governo do Equador. $\mathrm{O}$ bem viver reivindicado por essas mulheres não apresenta um conceito unificado, pelo contrário, tem significados diversos para cada comunidade, portanto, o conjunto de suas reivindicações visou garantir os meios básicos para que cada comunidade pudesse realizar sua noção de bem viver a partir de sua cosmovisão e de seus territórios (VALLEJO REAL; DUHALDE RUIZ, 2019).

Nelly Stromquist (2019) discute como as questões de gênero foram abordadas nas novas constituições do Equador e da Bolívia em relação às noções de bem viver. A autora aponta que embora ambos documentos contenham referências às mulheres eles não apresentam gênero como um fenômeno social com seus próprios contornos e características. $\mathrm{Na}$ Constituição equatoriana (2008), mulheres aparecem como um "grupo vulnerável” de forma similar a pessoas com deficiências e idosos (Artigo $47^{\circ}$ ). De forma similar, na Constituição boliviana (2009), mulheres são identificadas como parte de uma longa lista de grupos discriminados, a qual inclui cor, orientação sexual, origem, nacionalidade. Por outro 
lado, ambos documentos discutem os problemas relacionados ao trabalho não remunerado de mulheres.

A autora afirma que a partir da Revolução Cidadã proposta pelo governo do presidente Rafael Correa (2007 - 2017), é possível dizer que a situação política feminina prosperou no Equador. No entanto, o Equador apresentou um retrocesso em relação ao Índice Global de Desigualdade de Gênero (IGDG) do Fundo Monetário Internacional, o país que chegou a ocupar o $23^{\circ}$ lugar no ranking, caiu para $41^{\circ} \mathrm{em} 2018$. O cenário pós-constituinte equatoriano é marcado por um distanciamento entre movimentos sociais, principalmente indígenas e feministas, e o governo (STROMQUIST, 2019).

A Constituição boliviana, por sua vez, refere-se à necessidade não apenas de igualdade de oportunidades para homens e mulheres, mas também à necessidade de "abolir o domínio masculino e demolir o estado patriarcal" (AGUINAGA et al., 2012). De acordo com Jordana Foiatto (2019) dentre 149 países avaliados em 2018 pelo IGDG a Bolívia ocupa a 25 posição, seu alto status é garantido pela igualdade política obtida pela representatividade feminina, a qual foi conquistada através do sistema eleitoral de Paridade e Alternância instaurado em 2014 com base em diretrizes do Plano Nacional del Viver Bien. Segundo dados da União Interparlamentar (IPU, 2018), em 2018, as mulheres ocupavam 53\% dos cargos no Parlamento, sendo a terceira nação do mundo em participação feminina.

É evidente a eficácia do sistema que foi adotado no governo de Evo Morales, o qual pode servir como modelo de representatividade política igualitária para a região. Contudo, Ximena Roncal (2020) argumenta que embora a representação parlamentar boliviana demonstre avanços significativos, a realidade concreta em outras esferas de poder é bem diferente: apenas 8,5\% dos 339 municípios bolivianos são governados por mulheres e há uma única governadora.

Além disso, a Bolívia possui a maior taxa de feminicídios da América Latina, a cada três dias é assassinada uma mulher, à qual se soma uma média de nove atos diários de violência sexual (RONCAL, 2020). Em resposta a tal situação foi inaugurado em março de 2019 um gabinete especial de combate à violência contra as mulheres, o Servicio Plurinacional de la Mujer y de la Despatriarcalización, cuja prioridade é a desnaturalização da violência contra as mulheres e redução das taxas de violência no país. A unidade desenvolve estudos e programas para eliminar a diferença salarial entre mulheres e homens no setor privado; estratégias para reduzir a gravidez na adolescência; programas vinculados ao 
trabalho de meio período, para que mães e pais possam compartilhar o cuidado de seus filhos e filhas (RONCAL, 2020).

O Feminismo Comunitário tem sua história fortemente ligada ao movimento do bem viver na Bolívia. Julieta Paredes, poetisa aimara e uma das fundadoras do feminismo comunitário, foi assessora de políticas públicas de gênero durante o governo de Evo Morales, colaboração que influenciou a inclusão de pautas feministas e de despatriarcalização na Constituição boliviana de 2009 (PAREDES, 2015).

Julieta Paredes (2015) argumenta que, conceitualmente, o feminismo comunitário nasceu descolonizando o feminismo para restaurar as memórias das lutas antipatriarcais e definir o horizonte de "Bem Viver para todos os povos do mundo" (p. 07) e para a natureza que os abriga. Segundo a autora, na Bolívia, o feminismo comunitário contribuiu para a criação da estrutura conceitual das políticas públicas do governo de Evo Morales para fortalecer, fundamentalmente, as organizações sociais das mulheres.

Especificamente sobre a Bolívia e o Equador, no âmbito das noções de bem viver, desde que as novas Constituições entraram em vigor, um maior destaque é dado para a garantia dos direitos das mulheres. Em comparação com os antigos governos neoliberais é possível observar aumento significativo na preocupação com a população feminina por parte desses Estados. Nesse sentido, o esforço governamental foi traduzido em planos, cúpulas, conselhos, políticas e debates, sendo assim possível afirmar que algumas dessas iniciativas se desenvolveram e avançaram, mesmo com alguma debilidade em seu funcionamento.

Os feminismos e os estudos de gêneros na América Latina têm se desenvolvido em diversas áreas das ciências humanas e sociais, configurando um campo de investigação marcado por uma heterogeneidade epistemológica, teórica e metodológica. Possíveis desdobramentos para o campo psi devem considerar a interseccionalidade de opressões que as mulheres deste continente sofrem historicamente. Destacamos a relevância do conceito de interseccionalidade de determinantes de opressão (raça-etnia, gênero, classe, sexualidade entre outros). Trata-se de um constructo desenvolvido no âmbito do feminismo negro, que no campo psi tem contribuído para a compreensão das opressões sofridas por mulheres nos diferentes contextos latino-americanos, na análise das desigualdades sociais que caracterizam essas sociedades, auxiliando na definição de estratégias de enfrentamento mais adequadas.

Noções de bem viver articuladas por movimentos feministas latino-americanos são utilizadas na elaboração de novos horizontes possíveis, nas lutas por equidade nos planos 
sociais, econômicos e políticos, como ilustrado nos exemplos discutidos.

\subsubsection{Audiovisual}

Iniciada no final do século $\mathrm{XX}$, a Internet tornou-se um traço característico das sociedades ocidentais/ocidentalizadas no século XXI. Estimativas apontam que em torno de $54 \%$ da população mundial tenha algum tipo de acesso à rede mundial de computadores . As plataformas de mídia social reportam aproximadamente 3,5 bilhões de usuários ativos, as modalidades de ensino a distância $(\mathrm{EaD})$ estão em pleno crescimento e as ferramentas de compartilhamento de informação aumentam exponencialmente (ONU, 2019).

A plataforma de compartilhamento de arquivos audiovisuais Youtube, inaugurada em 2005, tornou-se uma ferramenta de uso diário para muitas pessoas como um meio rápido de acesso à informação, onde, frequentemente, é possível acessar registros audiovisuais de quem desenvolve o conteúdo pesquisado. Optamos por utilizar o Youtube para nossa pesquisa porque é a plataforma online aberta mais utilizada para compartilhamento de audiovisual no mundo. A ferramenta é razoavelmente democrática, pois não há custos para se manter um canal de divulgação de conteúdo e nem para acessar aos vídeos. Até a presente data, a plataforma informa que existem mais de 2 bilhões de usuários ativos, os quais assistem, aproximadamente, um total de 1 bilhão de horas diariamente.

A partir de uma revisão sistemática da literatura sobre a divulgação de informação na área da saúde no Youtube, Kapil Madathil e colegas (2014) afirmam que a grande variedade de obras disponíveis e de seus criadores é ao mesmo tempo fonte de qualidade e de riscos para pesquisas científicas. Embora haja grande incidência de obras sem referência bibliográfica, há também muitas obras de organizações de ensino apresentadas com rigor científico, tornando a difusão de informação altamente democrática.

Chareen Snelson (2016) produziu uma revisão de escopo sobre a pesquisa científica do uso do Youtube por instituições de ensino. A pesquisadora revisou 35 obras científicas produzidas entre 2008 e 2015 e constatou que há um aumento exponencial do uso da plataforma para fins educacionais e grande aderência por parte dos estudantes e ensinantes (como consumidores e produtores de vídeos educacionais), contudo, ainda existem poucas revisões de literatura sobre o tema e faltam parâmetros de classificação sobre a qualidade da informação disponibilizada. Logo, a utilização do Youtube para pesquisas científicas requer a avaliação rigorosa das referências de cada obra, de forma similar ao que se aplica para 
avaliação de bases de dados tradicionais.

Em se tratando de fonte diversa e democrática de literatura não convencional, consideramos a plataforma adequada para a presente pesquisa. Para além dos termos de busca relacionados ao bem viver e ao campo psi, foi adicionado o critério "número de visualizações de cada vídeo", ou seja, a popularidade da obra. O algoritmo de busca do Youtube seleciona e lista as obras mais relevantes de acordo com os termos de pesquisa e com o número de visualização. A partir desses resultados, selecionamos as obras que explicitaram as referências de sua abordagem.

Iniciamos nossa análise pelo canal com maior conteúdo sobre o tema, O Canal Buen Vivir TV, lançado em 2013, acumulou um total de mais de 800.000 visualizações, com aproximadamente 5.200 inscrições e mais de duzentos vídeos publicados. Foi uma ação da Secretaria del Buen Vivir do governo de Rafael Correa, encerrada com o fim do governo em 2017. A frente do canal estava Freddy Ehlers, conhecido apresentador de programas de televisão e jornalista equatoriano, nomeado Ministro da Secretaria del Buen Vivir, em Junho de 2013, durante o segundo mandato de Correa.

A missão da Secretaria del Buen Vivir (cujo orçamento foi de 12 milhões de dólares para uma gestão de quatro anos) era "impulsar una nueva forma de convivencia para el fomento de la investigación y el desarrollo del pensamiento, que trascienda las fronteras y promueva las prácticas ciudadanas responsables ligadas al Sumak Kawsay" (PRESIDENCIA DE ECUADOR, 2013), o conteúdo de seu canal, Buen Vivir TV, destinava-se à promoção de ações executadas pela Secretaria e à popularização das noções de bem viver apoiadas pelo governo da época.

A Secretaria realizou 21 pesquisas sobre diversos temas associados às noções de bem viver, dentre elas destacam-se diagnósticos para melhorar o sistema educativo, estudos sobre as raízes do pensamento indígena acerca do bem viver, análises de dados estatísticos de outros países que mensuram a felicidade.

Ao longo de quatro anos foram realizados 240 vídeos, combinados em três temas: Buen Vivir, Acuerdo para el Buen Vivir e Ecuador Ama la Vida. Além de serem disponibilizados no canal Youtube, esses programas foram transmitidos em cerca de 40 canais de televisão locais e nacionais equatorianos.

É evidente no conjunto dos vídeos a intenção didática de construir uma compreensão do que seria bem viver. Há também uma certa construção filosófica, uma apologia a modos de 
vida simples, de viver bem com pouco, em proximidade à "natureza". . Agricultura comunitária, cooperativas de trabalho, educação, nutrição, resgate de saberes ancestrais, cultura, yoga, meditação, esportes, entrevistas, e , sobretudo, a propagação do que seria a noção de bem viver equatoriana.

A segunda obra selecionada é um vídeo de Silvia Rivera Cusicanqui (2013), socióloga e historiadora boliviana de origem aimara, ativista vinculada ao Movimento Indianista Katarista e ao Movimento Cocalero e investigadora das cosmologias quechua e aymara. A pesquisadora foi entrevistada por Boaventura Souza Santos em 2013 e na entrevista relata suas impressões sobre as noções de bem viver, especificamente o suma qamaña, o termo mais difundido na Bolívia.

Segundo a socióloga, noções de bem viver surgem na cosmologia aimara a partir de formas ritualizadas de discurso, são aforismos, e que palavras e frases em aimara podem ter muitos significados diferentes. Como exemplo desses aforismos ela menciona (CUSICANQUI, 2013, 24m11s)

El suma q'amaña jakjam parlaña, jaqjam sarnaqaña es otro aforismo. Vivir bien quiere decir hablar como gente y caminar como gente. Y hablar como gente quiere decir: escuchar antes de hablar, decir cosas que sabes y no hablar de lo que no sabes, y refrendar tus palavras con tus actos... Pero a nadie le interesa saber eso porque es justamente lo que los gobernantes no hacem: no escuchan, hablan de lo que no saben y no compatibilizan sus actos con palabras.

Para a socióloga, a noção de bem viver é uma oportunidade de pensar um outro mundo a partir de outros princípios civilizatórios, diferente do pensamento moderno que prevalece até agora, uma nova visão que se afasta das dinâmicas de exploração das pessoas e do ambiente na lógica de acumulação do capital. Sobre a presença da noção de bem viver no cotidiano de alguns povos aymara, e em parte também por alguns movimentos indígenas, a pesquisadora relata que a possibilidade de um presente e um futuro de bem-estar social, de suma qamaña, é uma noção indígena chave, que se expressa em rituais, desenhos e outras formas imaginárias.

Finalmente, a pesquisadora aponta que o termo bem viver (sumak kawsay ou suma qamaña) foi apropriado pelo Estado de uma maneira superficial e fetichista, sem a preocupação de compreender seu sentido e sua origem. Apesar dessa apropriação representar avanços importantes, a pesquisadora argumenta que Estados buscam legitimar uma suposta plurinacionalidade pelo simples uso de termos em idioma indígena, em suas palavras, "la palabra legitima pertenece a los de arriba, los de bajo dan insumos. Lo mismo que em todo el 
sistema de conocimiento: nosotros produzimos materia prima y nos devuelven producto elaborado" (CUSICANQUI, 2013, 27m25s).

A terceira obra analisada é o canal youtube de Javier Lajo, intelectual quechua do Perú, estudioso das raízes da civilização andina e ativista social e político. Seu canal foi fundado em 2014 e conta com mais de 37.000 visualizações. Em seu vídeo "Qhapaq ñan: la dimensión sagrada", Lajo discorre sobre uma noção de bem viver a partir da cultura quechua cusquenha.

De acordo com Lajo, o Sumaq Kawsay, não é um assunto ético, pois não depende da convenção nem do formalismo humano, é um assunto da ordem natural, na qual o ser humano está obrigado, primeiramente, a compreender suas obrigações para com a natureza, em segundo lugar para assegurar o equilíbrio de sua convivência com a Pachamama e em terceiro lugar conviver bem com seus congêneres. Dentro dessa visão, Lajo afirma que bem viver é (LAJO, 2019, 2m11s):

Un concepto importante de la disciplina o modo de vida andino-amazónico, que tiene que ver en primer lugar con tres compromisos del ser humano con la Pachamama: hacer bien las cosas, hacerlas efectiva y realmente, o Allin Ruay; querer bien, desear el bien, o Allin Munay; pensar bien, razona bien, o Allin Yachay.

Lajo argumenta que o equilíbrio pleno para o sumaq kawsay é produto do equilíbrio entre sentir e pensar, o que incide num "agir pleno", equilibrado e consequente, no qual o critério de verdade é a consciência plena do momento e a própria circunstância do sumaq kawsay (existência esplêndida), como no ditado andino, "um agir, sentindo e pensando, de forma complementar e proporcional”.

O intelectual argumenta que a noção de bem viver quechua cusquenha contém uma mensagem essencial para a sociedade não indígena: a importância da mobilização de todos na busca pelo equilíbrio do planeta. Segundo Lajo, um aspecto importante da civilização quechua é a busca pela compreensão da natureza para garantir a continuidade da vida no planeta. Incontáveis templos e áreas de observação astronômica foram construídos com essa função, como, ainda hoje, é possível verificar na rota Qhapaq ñan, também conhecida como "La Ruta Inka de Sabiduría", um complexo sistema de caminhos que atravessa a Argentina, Chile, Bolívia, Peru, Equador e Colômbia.

A quarta obra é um documentário realizado pelo CIMI em abril de 2016, uma reflexão sobre as noções de bem viver a partir da contribuição de indígenas e dos indigenistas vinculados ao CIMI. Nos depoimentos das lideranças indígenas, foi frequente a associação 
entre a ideia de bem viver e de felicidade, como na fala de Zenilda Xukuru do Ororubá, "O bem viver para nós é, o que é ser feliz pensando no coletivo" (CIMI, 2016, 3m11s).

Saulo Feitosa, secretário adjunto do CIMI, relata que nem o capitalismo nem o socialismo aportaram para a humanidade a questão da natureza como centralidade, enquanto noções de bem viver posicionam a natureza como sujeito de direitos, pois a natureza expressa a integralidade de todos os seres, em suas palavras (CIMI, 2016, 8m42s)

Para contrapor o modelo capitalista, que oprime e destrói a natureza, e para avançar além da alternativa socialista, que foi experimentada e se mostrou incapaz de avançar na solução dos problemas dos homens e da natureza, o bem viver é um processo que vai levar a humanidade a uma nova realidade, onde haja comunhão equidade e felicidade entre todos.

A quinta obra audiovisual analisada, Diálogos del Buen Vivir con José Mujica, foi publicada em 2016 pelo canal Buen Vivir TV (discutido no início desta seção), está entre as mais assistidas dentro do tema, com quase 30.000 visualizações. O ex-presidente do Uruguai (2010 a 2015) é figura política emblemática da esquerda sul-americana, há muitos fatos marcantes em sua trajetória, como a luta contra a ditadura, legalização da maconha, legalização do casamento homoafetivo e direito ao aborto.

Mujica (2016) argumenta que a mensagem central das noções de bem viver é a compreensão da humanidade como espécie gregária e que é necessário pensar como espécie para encontrar soluções para a continuação da vida no planeta, sobretudo para uma vida mais feliz. Em sua opinião, as noções de bem viver representam propostas para recuperar o senso de comunidade, "la causa mas profunda de la infelicidad contemporanea, no es la riqueza o la pobreza, [...] en el fondo, és que estamos terriblemente solos" (MUJICA, 2016, 3m10s).

De acordo com o político, a sociedade de consumo é uma ilusão, onde a vontade de grande parte dos que vivem sob o sistema capitalista foi "sequestrada pela propaganda" e é muito difícil escapar disso, apontando que a utilização de noções de bem viver pelos Estados pode ser uma chave para a construção de sociedades mais felizes $(4 \mathrm{~m} 22 \mathrm{~s})$ :

Algunos dicen que ningún gobierno puede garantizar la felicidad, la felicidade es un estado personal, es interior de la persona, pero es falso. La felicidad necesita un meio ambiente, necesita un espacio para ser posible, necesita justamente que el resto de las cosas se miren a partir de la felicidad, y no como un resultado aleatorio que pudiera ser o no pudiera ser. [La felicidad] tiene que ser una preocupación central

Mujica aponta a necessidade de uma transformação cultural brutal, para a construção de uma sociedade pensada a partir dos sentimentos. Relacionando noções de bem viver com a ideia de felicidade, o político afirma que a felicidade deve ser introduzida definitivamente na 
plataforma do pensamento humano, pois, ela não aparecerá espontaneamente, “su construcción requiere un trabajo deliberado" (MUJICA, 2016, 5m43s).

O sexto vídeo selecionado foi "Enrique Dussel - Buen Vivir", publicado em Maio de 2018, com mais de 59.000 visualizações. Enrique Dussel, um expoente da filosofia da libertação, afirma que o bem viver significa, "en expressión, em distintas línguas, azteca, maya, chibcha, quechua, aimara, un proyecto de vida, es decir, aquello que unifica la existencia humana y permite dar un sentido a todo lo que acontece" (DUSSEL, 2018, $7 \mathrm{~m} 18 \mathrm{~s})$.

O filósofo argumenta que noções de bem viver, enquanto projetos de vida, apresentam atribuições de cunho místico e comunitário que fazem parte da vida de muitos povos indígenas em nosso continente. De acordo com Dussel, as referências à Pachamama (centrais nas noções de bem viver aymara e quechua), ou seja, a natureza como mãe, possuem um significado profundo de ordem prática, "és algo que más que una metáfora, realmente (la naturaleza) es nuestra madre porque nos ha producido y nosotros somos efecto de esa naturaleza” (2018, 10m35s).

Segundo Dussel (2018), faz-se necessária uma nova localização das culturas periféricas na história mundial, essas culturas periféricas foram colonizadas, desprezadas e ignoradas pelo projeto capitalista-moderno eurocentrado, porém, não foram eliminadas. O desafio que se coloca é o de estabelecer um diálogo intercultural e simétrico entre essas culturas a fim de responder de outros lugares os desafios da modernidade e pós-modernidade europeia.

Em resumo, o filósofo aponta que para assegurar a continuidade da vida humana na terra são necessárias mudanças paradigmáticas profundas e muito desafiadoras, incluindo hábitos de consumo, hábitos alimentares, modos de produção e da relação com a terra. Assim como o capitalismo o socialismo também foi um projeto moderno com objetivos quânticos, portanto um novo projeto civilizatório deve ser pensado no formato de um comunitarismo tecnológico. Tal projeto pressupõe um novo modo de realizar a vida, assim como no paradigma do bem viver, uma nova relação entre a humanidade e o todo onde se vive, com políticas e economias participativas, com relações igualitárias de raça, etnia e gênero.

A sétima obra analisada é o "Canal Bem Vivendo", inaugurado em 2018, produzido pelo socialista ambiental Thiago Ávila e seguido por mais de 21 mil inscritos. Ávila já publicou mais de 25 vídeos (até a presente data) nos quais encoraja a ruptura com a ideologia 
produtivista do progresso e promove a proteção da natureza, discutindo os avanços da crítica ecológica para transformação social.

Ávila também participa e promove em seus vídeos o movimento social Mutirão do Bem Viver, o qual consiste na formação de grupos de voluntários para promover ações de transformação social em benefício de pessoas em condição de vulnerabilidade social, como a construção de moradias com tecnologia de bioconstrução, defesa de territórios indígenas, cultivo sustentável e distribuição de alimentos.

Além de discutir formas equilibradas de integrar a preservação do meio ambiente com necessidades sociais, Ávila utiliza as plataformas onlines para o combate a desigualdade social, promovendo como horizonte de transformação uma noção de bem viver comum, a partir de experiências inspiradas nas cosmovisões dos povos indígenas latino-americanos (ÁVILA, 2020). Ávila afirma que "enfrentar o capital para construir, em seu lugar, uma nova sociedade do bem viver é o principal desafio de nossa geração" (2020, 3m31s).

A última obra selecionada é o vídeo dos intelectuais indígenas Daniel Munduruku e Kaká Werá (2019). O vídeo “A arte do Bem Viver: Conversa com Kaká Werá” está publicado no canal youtube "TV Daniel Munduruku", produzido pelo intelectual e que contém mais de uma centena de vídeos sobre cultura e movimentos indígenas.

No vídeo, Werá compartilha a noção de bem viver que aprendeu junto ao povo Guarani da aldeia Krukutu, em São Paulo. Nessa visão, o bem viver está ligado a ideia de Tekoa, um bom lugar para se viver, e depende de quatro dimensões principais: um território de natureza farta, com água, vegetação abundante, montanhas e pedras; o respeito e a conexão com os ancestrais; o respeito na relação com todos os seres e uma noção de inclusão profunda entre os seres, considerando a todos os seres como uma grande família, uma noção de parentesco. Werá argumenta que a sociedade não indígena tem muito a aprender com as noções de bem viver, porque as noções de qualidade de vida nessa sociedade são demasiadamente individualizadas e não incorporam noções de sustentabilidade, nem de preservação do meio ambiente.

Munduruku ratifica a visão de Werá, afirmando que as noções de bem viver representam um contraponto à sociedade de consumo. $\mathrm{O}$ escritor argumenta que as noções de qualidade de vida na sociedade de consumo, em geral, depositam maior importância aos objetos do que às pessoas, substituem a convivência com outros seres pelo consumo de objetos. O intelectual acrescenta que as sociedades não indígenas, em sua maioria, ignoram 
que a noção de propriedade privada é apenas uma convenção de algumas sociedades, pois somos "seres de passagem, e dessa passagem o principal é saber conviver em harmonia com todos os seres e com o ambiente." (2019, 4m13s).

Incorporamos esse panorama de obras sobre noções de bem viver no Youtube para refletir a mudança de comportamento social no campo da transmissão de conhecimento e do entretenimento. A indústria do entretenimento de massa também tem sido afetada pelas plataformas de compartilhamento de material audiovisual gratuito, as quais possibilitam que uma quantidade expressiva de pessoas marginalizadas devido a marcadores de raça-etnia, classe social, gênero e sexualidade, tenham se tornado produtoras e protagonistas de conteúdo. Em 2018, uma média mensal de 133 milhões de pessoas utilizaram o Youtube no Brasil, esse número vem crescendo a uma taxa de $15 \%$ ao ano, o Brasil é o terceiro país em utilização do Youtube em números absolutos (WEARESOCIAL, 2019). Em um sentido descolonial essa mudança de comportamento possibilita uma desmonopolização do conhecimento e do entretenimento.

Salientamos que o presente texto foi finalizado durante o período de quarentena do coronavírus no estado de São Paulo, iniciado pela Reitoria da USP em 17 de Março de 2020 e sem previsão de data final. Desde a suspensão de atividades presenciais na USP a utilização de ferramentas de compartilhamento de conhecimento online tem se intensificado, por consequência as plataformas de compartilhamento de material audiovisual, como o Youtube, têm se tornado ainda mais presentes no cotidiano de docentes, discentes e da sociedade como um todo.

Em relação às noções de bem viver na perspectiva da psicologia, consideramos que o Youtube disponibiliza vasta gama de fontes, com acesso e divulgação razoavelmente democráticos, considerando o relativo acesso aos meios tecnológicos das diferentes populações, publicação e ferramentas de compartilhamento gratuitas. Embora não tenhamos encontrado material especificamente produzido com foco no campo psi, foi possível acessar material relevante para o campo psi produzido por intelectuais indígenas, indigenistas e expoentes de campos diversos do conhecimento. 


\section{LIÇÕES APRENDIDAS}

Assumindo que nas ciências não há neutralidade, não há psicologia que não seja política. Logo, consideramos importante destacar nossa linha principal de análise citando a socióloga e historiadora boliviana de origem aimara, Silvia Rivera Cusicanqui (2013, $39 \mathrm{~m} 20 \mathrm{~s})$ :

Yo no creo que la ecología de saberes tenga que ser solamente entre oprimidos, sino que, es necesario poner en reunión grandes epistemes incluyendo el legado europeo, es decir, creo que es necesario recuperar las luchas del trabajo, el aporte anarquista, la noción de los derechos de la persona, de libertad, por ejemplo, la noción de libertad prácticamente no es compatible, o no existe, en ciertas formas indígenas de organización, pero la ecología de saberes seria para mi como la epistemología ch 'ixi, repensar los legados tanto de las sociedades comunitarias como del mundo del trabajo ya influido por modos, digamos, individualistas, para poner en discusión una especie de esfera intermedia en la cual se formule esta dualidad de un modo creativo

A psicologia social latino-americana exemplifica esses encontros epistêmicos quando coloca em diálogo igualitário os conhecimentos dos povos indígenas e comunidades tradicionais deste continente com abordagens das psicologias ocidentais eurocêntricas e estadunidenses. Esta abordagem intercultural visa fomentar projetos civilizatórios que possibilitem boas condições de existência para todos os seres, levando em conta as especificidades e os conhecimentos de povos diversos, bem como o seu protagonismo, na busca de um bem viver para todos. Assim, a utilização da interculturalidade, enquanto ferramenta pedagógica que coloca em diálogo diferenças em um marco de legitimidade, igualdade e respeito, é uma das importantes lições que aprendemos.

Seria a interculturalidade, em suas diversas expressões, um horizonte de reparo, um horizonte para transcender o violento passado das Américas? Na América Latina, a violência é um tema que perpassa todos os âmbitos da existência, ela está presente em todas as expressões de desigualdades sociais, pois, esses abismos sociais são, por si mesmos, violências que são perpetuadas pelo sistema capitalista e se desdobram em novas violências, num ciclo alimentado desde a invasão das Américas no século XV. Assim, noções de bem viver, articuladas dentro das especificidades de cada povo, contextualizadas em relações interculturais equilibradas, poderiam ser possibilidades de realização das potências individuais e coletivas, de comunidades convivendo em maior reciprocidade e afeto, a despeito, porém sem se esquecer, de um passado comum de atrocidades. 
Outra lição que enfatizamos é a utilização da categoria interseccionalidade de opressões, oriunda do feminismo negro, no campo psi. Na América Latina, para se discutir qualidade de vida ou noções de bem viver é primordial considerar a interseccionalidade dos determinantes de opressão que incidem sobre nossos povos, sobretudo os determinantes de raça-etnia, gênero, classe e sexualidade.

Várias vertentes do feminismo latino-americano têm articulado as noções de bem viver em suas lutas sociais, como um horizonte, uma utopia a ser realizada. Esses feminismos se organizam para lutar por condições dignas de existir, considerando os efeitos das intersecções de determinantes de opressão (como raça-etnia, gênero e classe) específicos para cada comunidade, e aplicando essa compreensão em suas lutas por igualdade e equidade de gênero, defesa e acesso ao território, preservação do meio ambiente, entre outras.

As lutas dos feminismos latino-americanos remetem a reflexões sobre os epistemicídios que marcam o próprio saber acadêmico (GROSFOGUEL, 2016), como mencionado anteriormente, os genocídios/epistemicídios dos povos originários das Américas, dos povos de África e das mulheres. Refletir sobre noções de bem viver incide em refletir sobre o racismo/sexismo epistêmico que permeia todos os aspectos da existência. Nas obras que analisamos, os movimentos sociais e políticos inspirados nas cosmovisões de povos indígenas apresentam horizontes anticoloniais para transformação social que, em sua grande maioria, refletem e se posicionam na luta anti racismo/sexismo, através do resgate e fortalecimento de outros saberes, outras formas de viver e outros projetos civilizatórios contrários aos projetos imperiais, coloniais e patriarcais.

Em relação a aspectos metodológicos no campo psi, ainda há pouca pesquisa envolvendo constructos e abordagens específicos da psicologia que articulem noções de bem viver. Nota-se, principalmente, a escassez de pesquisa quantitativa, experimental ou com intervenções junto às populações, de acordo com Garcia, Berroeta e Castilho (2013, p. 110):

Hay algunos trabajos con métodos mixtos y muy pocos solo con miradas cuantitativas o experimentales incluyendo el uso de escalas o cuestionarios. Esto es congruente con las posturas orientadas a conseguir una comprensión profunda desde la mirada de las personas participantes de los diversos problemas, y también es indicativo de la necesidad de involucrar a las comunidades en los esfuerzos para su desarrollo. Sin embargo, preocupa un poco el no tomar en cuenta las ventajas o contribuciones de la investigación cuantitativa que no por ser merecedora de diversas criticas carece de utilidad.

Levando em consideração as críticas sobre o caráter universalizante, ou adaptacionista, 
que pesquisas quantitativas podem apresentar, acreditamos que métodos de pesquisa que combinem abordagens quantitativas e qualitativas, no campo psi, podem oferecer benefícios ao aumentarem chances de identificação de possíveis tendências em determinadas populações, considerando suas especificidades históricas, econômicas, sociais e políticas. Tendências que podem ser perscrutadas e discutidas em profundidade através de ferramentas qualitativas.

Salientamos também a importância da investigação de constructos psicológicos à luz de cosmovisões de povos indígenas. Haja vista a centralidade da relação com o território nessas cosmovisões, vislumbramos potencial para estudos epigenéticos no campo psi, considerando como fatores ambientais e fatores genéticos se vinculam em populações de cosmovisões distintas. Investigações realizadas nos últimos anos apontam correlações entre experiências vividas e efeitos em estruturas e funções cerebrais, e como estas influem no posterior desenvolvimento psicológico e emocional (MÍGUEZ-BURBANO et al., 2014). Parte essencial do conceito de epigenética é a interação entre pessoa (sua carga genética) e contexto.

Há potencial para ampliar a discussão no campo psi, sobretudo, porque se trata de uma nova abordagem de investigação sobre qualidade de vida, categoria analítica que tem atraído, por décadas, o interesse de pesquisadores em diversos campos científicos, sobretudo no campo da saúde. Estudos sobre qualidade de vida têm se tornado, cada vez mais, relevantes face à crise do projeto civilizatório capitalista que se agrava a passos rápidos, haja vista a crise global envolvendo a pandemia de Covid-19. Logo, é notório o crescente interesse de grandes organizações globais, como a ONU e a OMS, por índices que possam mensurar qualidade de vida para além de questões materiais.

Ainda no que se refere ao emprego de métodos de pesquisa, consideramos que plataformas de compartilhamento de material audiovisual online (como o Youtube) conquistaram um espaço no campo da transmissão de conhecimento que é irrefutável e cresce exponencialmente. Para o desenvolvimento desta pesquisa, foi de grande valor o acesso gratuito a obras de acadêmicos, militantes e políticos contemporâneos, através de registros audiovisuais de congressos, entrevistas, documentários ou vídeos feitos para seus próprios canais no Youtube. Como já relatado, esta Dissertação foi concluída durante a quarentena da pandemia da Covid-19, logo, as ferramentas de compartilhamento de informação e ensino a distância foram essenciais para possibilitar sua conclusão. Os desafios e lições que um mundo em quarentena apresenta, reforçam nossa hipótese sobre a relevância de incluir fontes de 
compartilhamento audiovisual em pesquisas científicas. Dentre os desdobramentos desta pesquisa, decidimos colocar maiores esforços na produção e difusão de material audiovisual online.

Um debate frequente concerne a origem das noções de bem viver junto aos povos originários. Embora nosso objetivo não tenha incluído uma investigação genealógica, não se pode ignorar os debates em torno das origens dessas noções, sobretudo as que estão cristalizadas nas Constituições do Equador e da Bolívia. A partir de um trabalho de campo com 20 povos indígenas na Bolívia, Beatriz Ascarrunz (2013) relata que: embora não tenha encontrado uma compreensão equivalente sobre o significado do bem viver cristalizado na Constituição boliviana, os povos estudados expressam maneiras particulares de conceber expectativas de vida e do cotidiano, as quais organizam a vida comunitária, como, por exemplo, maneiras de planificar o ano agrícola em benefício comum.

A comparação entre obras e investigações com povos diferentes foi fundamental para podermos compreender como essas noções se apresentam de diversas maneiras, sobretudo ao compararmos obras sobre os povos originários no Brasil com obras envolvendo separadamente os povos Aimara e Quéchua. Por exemplo, é possível verificar produções científicas no Brasil sobre noções do "bom modo de ser" Guarani (teko porã ou ñandereko), desde os anos 70 (MELIÁ, 2015), ao passo que no plano político e dos movimentos sociais indígenas no Equador, os primeiros registros datam de 1992 (VITERI, 2003).

Acreditamos ser de relevância para o campo psi reflexões que emergem a partir das articulações das noções de bem viver, inspiradas em cosmovisões indígenas, com noções de saúde e qualidade de vida oriundas da psicologia, visando a associação de práticas de bemestar coletivas e individuais, à luz das especificidades das comunidades com as quais se trabalha.

As obras que incluíram trabalhos com comunidades para formar uma compreensão de qualidade de vida a partir de suas realidades, considerando percursos históricos, condições de produção material, interseccionalidade de opressões e eixos de força particulares de cada povo ou comunidade, apontam oportunidades relevantes para o campo psi (CHAMORRO, 2011; LAJO, 2016; SOUSA, 2018; WERÁ, 2019), dentre as quais destacamos as diferentes noções de saúde, educação, reciprocidade, relação com a terra e espiritualidade.

Destacamos também a relevância da espiritualidade como um aspecto do bem viver em determinadas comunidades na América Latina. As discussões sobre qualidade de vida no 
âmbito acadêmico, notadamente à luz dos epistemicídios acima discutidos, tendem a ignorar a centralidade da espiritualidade no cotidiano comunitário. Em muitas comunidades a noção de bem viver é intrinsecamente vinculada à espiritualidade praticada, ou seja, a dimensão material está em constante interação com outra ou outras dimensões. Logo, futuras investigações nesse domínio devem se aprofundar nesse sentido, utopias de bem viver também refletem possibilidades de transcender situações em dimensões diversas, não necessariamente materiais.

Uma das características centrais das noções de bem viver é a compreensão de um bom conviver entre todos os seres, uma vida boa numa perspectiva coletiva. Enfatizamos que novas pesquisas no âmbito de qualidade de vida devem envolver os aspectos da vida comunitária, como as manifestações de solidariedade, reciprocidade, trabalho coletivo, formas de partilha e como esses aspectos se relacionam para criar noções de território, pertencimento e saúde.

Nesse sentido, os aspectos comunitários presentes nas noções de bem viver têm alterado a própria forma de trabalhar dos pesquisadores envolvidos no grupo de pesquisa “Psicologia e Relações Étnico-Raciais", coordenado pelo Professor Alessandro. Inspirados por essas noções, temos promovido discussões sobre formas de colaborar pensando o bem viver no cotidiano de nosso grupo de pesquisa, onde presentemente colaboram dez intelectuais, que desenvolvem seus projetos de iniciação científica, mestrado, doutorado e pós-doutorado. Dentre nossas propostas, primamos por formas de colaborar que fomentem um sentimento de comunidade, através de solidariedade, que alimente relações de longo prazo em um ambiente alegre. Nosso objetivo é que esse espaço de trabalho seja um ambiente propício ao bom conviver das pessoas que estão envolvidas, colaborando para a realização do bem viver nos âmbitos individuais e coletivos. 


\section{CONSIDERAÇÕES FINAIS}

Os movimentos sociais, políticos e acadêmicos que têm discutido noções de bem viver indígena, a partir do século XXI, apresentam um comprometimento em desenvolver práticas e teorias que considerem as repercussões da invasão da América Latina pelos povos europeus, trabalhando em soluções e respostas aos mais de 500 anos de opressão contra os povos indígenas.

As noções de bem viver não sugerem uma volta utópica a um passado idealizado (antes da invasão europeia). Trata-se de propostas de bem-estar a partir de dinâmicas coletivas, propostas interculturais e projetos de existir em equilíbrio com o espaço onde se vive e com todos os seres vivos, inclusive a compreensão do próprio planeta como organismo vivo.

O capitalismo global enquanto mecanismo organizador da sociabilidade, contribui para a acumulação material de uma parcela da sociedade em detrimento de outras. $\mathrm{O}$ que fomenta noções de qualidade de vida baseadas na individualidade e no consumo, amparadas em uma estrutura hierarquizada por marcadores sociais de raça-etnia, gênero e classe. Por outro lado, as noções de bem viver latino-americanas configuram formas alternativas de sociabilidade, priorizando o bem-estar coletivo, a partir de noções de reciprocidade e afetividade nas relações, divisão igualitária de recursos, relações de equilíbrio com o espaço de vida e combate às opressões baseadas em marcadores sociais. Portanto, a contribuição desta pesquisa para o campo psi, envolve a reflexão política sobre o tipo de sociabilidade fomentada em cada intervenção psicossocial.

Finalmente, como representantes de uma psicologia social latino-americana comprometida com as lutas sociais, almejamos que o saber científico seja refletido em transformação social. O aprendizado angariado no exercício desta pesquisa será refletido em propostas de novos indicadores e ferramentas de aferição de qualidade de vida, com base nas cosmovisões, nos saberes e nas realidades sócio-históricas de cada povo com o qual se colabora. Por fim, nossa sugestão para o âmbito do desenvolvimento de políticas públicas é que se leve em consideração, para a elaboração e aferição de resultados, dois aspectos centrais: o conjunto de opressões e desigualdades sociais, incluindo racismo, sexismo e injustiças históricas; e a compreensão do que é uma vida desejável de acordo com os saberes, peculiaridades e modos de viver de cada povo. 


\section{REFERÊNCIAS}

ACOSTA, Alberto. O Bem Viver: uma oportunidade para se imaginar outros mundos. Tradução de T. Breda. São Paulo, SP: Editora Elefante, 2014.

El Buen Vivir como alternativa al desarrollo. Algunas reflexiones económicas y no tan económicas. Política y sociedad, v. 52, n. 2, p. 299-330, 2015.

ACOSTA, Alberto; MARTÍNEZ, Esperanza. La naturaleza con derechos: de la filosofía a la política. Polis, Revista de la Universidad Bolivariana, v. 10, n. 29, p. 479-485, 2011.

ADAMS, Jean et al. Searching and synthesising 'grey literature'and 'grey information'in public health: critical reflections on three case studies. Systematic reviews, v. 5, n. 1, p. 164, 2016.

ALBÓ, Xavier. Suma qamaña = convivir bien.¿ Cómo medirlo? In: FARAH, I.; VASAPOLLO, L., Vivir bien:¿ Paradigma no capitalista. La Paz, Bolívia: CIDESUMSA, p. 133-144, 2011.

ALCÂNTARA, Liliane Cristine; SAMPAIO, Carlos Alberto Cioce. Bem Viver: uma perspectiva (des) colonial das comunidades indígenas. Revista Rupturas, v. 7, n. 2, p. $1-31,2017$.

ARTICULAÇÃO DE MULHERES NEGRAS BRASILEIRAS. (2015). Manifesto da Marcha das Mulheres Negras 2015 contra o racismo, a violência e pelo Bem Viver: o Bem Viver como nova utopia. Recuperado de: http://www.amnb.org.br/biblioteca.asp? id=152\#ancora. Acesso em: 20 mar. 2020.

ARKONADA, Katu. Transiciones hacia el Vivir Bien. Barcelona: Icaria Editorial, 2012.

ARKSEY, Hilary; O'MALLEY, Lisa. Scoping studies: towards a methodological framework. International journal of social research methodology, v. 8, n. 1, p. 19-32, 2005 .

ARMSTRONG, Rebecca et al. 'Scoping the scope'of a cochrane review. Journal of Public Health, v. 33, n. 1, p. 147-150, 2011.

ASCARRUNZ, Beatriz. Nada bien le hace al nuevo concepto del Vivir Bien la "idealización" de los pueblos indígenas. Vivir Bien: infancia, género y economía. Entre la teoría y la práctica. La Paz: Cides-Umsa, 55-66, 2013.

AUlete, Caldas. Dicionário contemporâneo da Língua Portuguesa. 3. ed. Rio de Janeiro: Delta, 1980. v. 5.

BANIWA, Gersem dos Santos Luciano. O índio brasileiro: o que você precisa saber sobre os povos indígenas no Brasil de hoje. Brasília: Ministério da Educação, Secretaria de Educação Continuada, Alfabetização e Diversidade, 2006. 
BOLÍVIA. Constituição (2009). Constituição Política do Estado Plurinacional da Bolívia. La Paz, Bolívia. Assembleia constituinte de Bolívia, 2009.

BRASIL. Ministério da Saúde. Secretaria Especial de Saúde Indígena. Departamento De Atenção à Saúde Indígena. Coordenação-Geral de Atenção Primária à Saúde Indígena. Documento orientador sobre a gestão da atenção psicossocial nos DSEI. 2014. Disponível em: http://conselho.saude.gov.br/ultimas_noticias/2018/6cnsi/DOCUMENTO_ORIENTAD OR 6a CNSI.pdf. Acesso em: 02 mar. 2020.

CHAMORRO, Graciela. A arte da palavra cantada na etnia kaiowa. Bulletin-Société suisse des américanistes, n. 73, p. 43-58, 2011.

COLQUHOUN, Heather et al. Scoping reviews: time for clarity in definition, methods, and reporting. Journal of clinical epidemiology, v. 67, n. 12, p. 1291-1294, 2014.

CONSELHO FEDERAL DE PSICOLOGIA. Referências técnicas para atuação de psicólogas(os) com povos tradicionais. Brasília, 2019. Disponível em: https://site.cfp.org.br/publicacao/referencias-tecnicas-para-atuacao-de-psicologasoscom-povos-tradicionais/. Acesso em: 02 mar. 2020.

CONSELHO INDIGENISTA MISSIONÁRIO. Jornal Porantim. O Bem Viver Indígena e o Futuro da Humanidade. Brasília, 2015. Disponível em: https://cimi.org.br/wp-content/uploads/2020/01/Porantim381_Dez_Encarte-2015.pdf. Acesso em: 02 mar. 2020.

CONSELHO REGIONAL DE PSICOLOGIA DE SÃO PAULO. Povos Indígenas e Psicologia: A procura do bem viver. São Paulo, 2016. Disponível em: http://www.crpsp.org/fotos/pdf-2016-08-24-16-20-25.pdf. Acesso em: 02 mar. 2020.

CORAGGIO, José Luis. La economía social y la búsqueda de un programa socialista para el siglo XXI. Revista Foro, n. 62, p. 37-54, 2007.

CUBILlO-GUEVARA, Ana Patricia. Genealogía inmediata de los discursos del buen vivir en Ecuador (1992-2016). América Latina Hoy, n. 74, pp. 125-144, 2016.

CUBILlO-GUEVARA, Ana Patricia; HIDALGO-CAPITÁN, Antonio Luis; DOMÍNGUEZ-GÓMEZ, José Andrés. El pensamiento sobre el Buen Vivir. Entre el indigenismo, el socialismo y el posdesarrollismo. Revista del CLAD Reforma y Democracia, n. 60, p. 27-58, 2014.

. El sumak kawsay genuino como fenómeno social amazónico ecuatoriano.

OBETS. Revista de Ciencias Sociales, v. 10, n. 2, pp. 301-333, 2015.

Emergencia, deconstrucción (y síntesis) del buen vivir latinoamericano. Revista Iberoamericana de Economía Solidaria e Innovación Socioecológica: RIESISE, n. 2, p. 189-210, 2019. 
CUBILlO-GUEVARA, Ana Patricia; HIDALGO-CAPITÁN, Antonio Luis; DOMÍNGUEZ-GÓMEZ, José Andrés. El pensamiento sobre el Buen Vivir. Entre el indigenismo, el socialismo y el posdesarrollismo. Revista del CLAD Reforma y Democracia, n. 60, p. 27-58, 2014.

CUSICANQUI, Silvia Rivera. Entre el Buen Vivir y el Desarrollo: una perspectiva indianista. ERREJÓN, Inigo; SERRANO, Alfredo ; Ahora es cuando, carajo! La Paz: El Viejo Topo, 2011. p. 169-180.

DEPOLE, Bárbara de Fátima. A produção brasileira sobre o projeto terapêutico singular: revisão de escopo. 2018. Dissertação (Mestrado) - Centro de Ciências Biológicas e da Saúde, Universidade Federal de São Carlos, São Carlos. 2018.

DUSSEL, Enrique. Siete hipótesis para una estética de la liberación. Revista PRAXIS, n. 77, p. 1-37, 2018.

EQUADOR. Constituição (2008). Constituição Política da República do Equador. Quito, Equador. Assembleia nacional constituinte do Equador, 2008.

ESCOBAR, Arturo. Degrowth, postdevelopment, and transitions: a preliminary conversation. Sustainability Science, v. 10, n. 3, p. 451-462, 2015.

FREIRE, Paulo. Pedagogia do Oprimido. Rio de Janeiro: Paz e Terra, 1970.

. Conscientização. São Paulo: Moraes, 1980.

FUNAI. O Brasil Indígena. Disponível em: http://www.funai.gov.br/index.php/indiosno-brasil/quem-sao. Acesso em: 02 mar. 2020.

GROSFOGUEL, Ramón. A estrutura do conhecimento nas universidades ocidentalizadas: racismo/sexismo epistêmico e os quatro genocídios/epistemicídios do longo século XVI. Sociedade e Estado, v. 31, n. 1, p. 25-49, 2016.

GUDYNAS, Eduardo. Bem-Viver: Germinando alternativas ao desenvolvimento. América Latina em Movimento-ALAI, n. 462, p. 1-20, 2011.

GUTIÉRREZ, Gustavo. Teologia da libertação. Perspectivas. Tradução Yvone Maria de Campos Teixeira da Silva. São Paulo: Edições Loyola, 2000.

GUZZO, Raquel Souza Lobo. A (des) igualdade social e a Psicologia: uma perspectiva para o debate sobre a pobreza. In: XIMENES, V. et al., Implicações Psicossociais da pobreza: diversidades e resistências. Fortaleza, CE: Expressão Gráfica e Editora, p. 149-162, 2016.

HIDALGO CAPITÁN, Antonio Luis; CUBILlO GUEVARA, Ana Patricia. Seis debates abiertos sobre el sumak kawsay. Íconos revista de ciencias sociales, v. 18, n. 48, p. 25-40, 2014. 
Deconstrucción y genealogía del "buen vivir" latinoamericano. El (trino)“buen vivir" y sus diversos manantiales intelectuales. International Development Policy| Revue internationale de politique de développement, v. 9, n. 9, 2017.

LE QUANG, Matthieu; VERCOUTÈRE, Tamia. Ecosocialismo y Buen Vivir: diálogo entre dos alternativas al capitalismo. Quito: Editorial IAEN, 2013.

LEVAC, Danielle; COLQUHOUN, Heather; O'BRIEN, Kelly. Scoping studies: advancing the methodology. Implementation science, v. 5, n. 1, p. 69, 2010.

LÖWY, Michael. Marxismo e teologia da libertação. São Paulo: Cortez, 1991.

MALAMUD, Andrés. O que aconteceu com Evo Morales na Bolívia é um golpe de Estado? El país, Brasil, 19 nov. 2019. Disponível em: https://brasil.elpais.com/brasil/2019/11/11/internacional/1573500916 562089.html.

Acesso em: 20 de abr. 2020.

MARTÍN-BARÓ, Ignácio. El papel del psicólogo en el contexto centroamericano. Boletín de psicología, v. 17, n. 3, p. 99-112, 1985. 1986.

Hacia una psicologia de la liberación. Boletín de psicología, n. 22, p. 219-231,

MARTÍNEZ NOVO, Carmen. Discriminación y colonialidad en el Ecuador de Rafael Correa (2007-2017). Alteridades, v. 28, n. 55, p. 49-60, 2018.

MELIÀ, Bartolomeu. O bem viver guarani: tekó porã. Servicios Koinonia de la Agenda Latinoamericana. n. 14, p. 116-117, 2012.

El buen vivir se aprende. Sinéctica, n. 45, p. 1-12, 2015.

MIGNOLO, Walter. La colonialidad a lo largo ya lo ancho: el hemisferio occidental en el horizonte colonial de la modernidad. 2000. Disponível em http://people.duke.edu/ wmignolo/publications/articles1.html. Acesso em: 2020-05-04.

MÍGUEZ-BURBANO, María José et al. Mood disorders and BDNF relationship with alcohol drinking trajectories among PLWH receiving care. Journal of alcoholism and drug dependence, v. 2, n. 2, p. 148, 2014.

MOHER, David; STEWART, Leslie; SHEKELLE, Paul. All in the family: systematic reviews, rapid reviews, scoping reviews, realist reviews, and more. Systematic Reviews Journal, v. 4, n. 1, p. 183, 2015.

MONTERO, Maritza et al. Psicología social comunitaria. Guadalajara, México: Universidad de Guadalajara, 1994.

ORTIZ FERNANDES, Carolina. Felipe Guaman Poma, Clorinda Matto de Turner, Trinidad Enríquez y la teoría crítica. Sus legados a la teoría social contemporánea. In: QUIJANO, Aníbal. Des/colonialidad y bien vivir: un nuevo debate en América Latina. 
Lima, Peru: Universidad Ricardo Palma, Editorial Universitaria, Cátedra América Latina y la Colonialidad del Poder, 2014. p. 101-136.

PETERS, Micah et al. Methodology for JBI scoping reviews. In: The Joanna Briggs Institute Reviewers manual 2015. The Joanna Briggs Institute, p. 3-24, 2015.

PRESTES, Clélia Rosane dos Santos. Estratégias de promoção da saúde de mulheres negras: interseccionalidade e bem viver. 2018. Tese (Doutorado em Psicologia Social) Instituto de Psicologia, Universidade de São Paulo, São Paulo, 2018. doi:10.11606/T.47.2018.tde-14112018-184832. Acesso em: 2020-05-04.

QUIJANO, Anibal. Colonialidad del poder, eurocentrismo y América Latina. In: LANDER, Edgard. La colonialidad del saber: eurocentrismo y ciencias sociales. Buenos Aires: CLACSO, p. 122-151, 2000.

Des/colonialidad y bien vivir: un nuevo debate en América Latina. Lima, Peru: Universidad Ricardo Palma, Editorial Universitaria, Cátedra América Latina y la Colonialidad del Poder, 2014.

Bien Vivir: Entre el desarrollo y la Des/Colonialidad del poder. Horizontes sociológicos, n. 1, p. 25-38, 2015.

RAMÍREZ, René. Socialismo del Sumak Kawsay o biosocialismo republicano. In: SENPLADES: Los nuevos retos de América Latina: socialismo y Sumak Kawsay. Quito: SENPLADES, v. 1, 2010, p. 55-76. Disponível em: http://www.dhls.hegoa.ehu.eus/documents/4960. Acesso em: 02 mar. 2020.

ROCCO, Fernando Viana de Carvalho. Intervenções de prevenção positiva: uma revisão de literatura. 2018. Dissertação (Mestrado em Psicologia Social) - Instituto de Psicologia, Universidade de São Paulo, São Paulo, 2018. doi:10.11606/D.47.2018.tde18042018-152430. Acesso em: 2020-05-04.

RYAN, Richard M.; DECI, Edward L. On happiness and human potentials: A review of research on hedonic and eudaimonic well-being. Annual review of psychology, v. 52, n. 1, p. 141-166, 2001.

SALOMÃO, Eduardo Rizzatti. O exército encantado de São Sebastião: as evidências da crença sebastianista na Guerra do Contestado (1912-1916). Revista Eletrônica História em Reflexão, v. 3, n. 5, 2009.

SANTOS, Alessandro de Oliveira dos; SCHUCMAN, Lia Vainer; MARTINS, Hildeberto Vieira. Breve histórico do pensamento psicológico brasileiro sobre relações étnico-raciais. Psicologia: Ciência e Profissão, v. 32, n. SPE, p. 166-175, 2012.

Psicologia e relações ètnico-raciais: perfil e tendência dos estudos publicados em periódicos psi no período de 2010 a 2013. Psicologia e políticas pública na amazônia: pesquisa, formação e atuação, 2014.

SEGATO, Rita Laura. Las nuevas formas de la guerra y el cuerpo de las mujeres. Sociedade e Estado, v. 29, n. 2, p. 341-371, 2014. 
SECRETARÍA NACIONAL DE PLANIFICACIÓN DEL DESAROLLO (SENPLADES). Plan Nacional del Buen Vivir 2009-2013. Quito, Equador, 2009.

Recuperación del Estado para el Buen Vivir. Quito, 2011.

Transformación de la matriz productiva. Quito, Equador, 2012.

SILVA, Lemuel Rodrigues. História e memória: narrativas memoráveis sobre a marcha de Lampião em mossoró. In: V COLÓQUIO DE EXTENSÃO DA UERN: EXTENSÃO E SEMIÁRIDO NA CONTEMPORANEIDADE, 2011, Mossoró. Anais... Mossoró: UERN, 2011. p. 31.

SILVA PRESTES, Fabiane. O bem viver kaingang: as conexões entre os princípios da teoria do buen vivir e os saberes tradicionais que orientam o seu modo de ser. 2018. Tese (Doutorado em Ambiente e Desenvolvimento) - Pós-Graduação em Ambiente e Desenvolvimento, Universidade do Vale do Taquari, Lajeado, 2018.

SIMÕES GONÇALVES, Bruno. A Dupla Consciência Latino-Americana: contribuições para uma psicologia descolonizada. Revista Psicologia Política, v. 16, n. 37, p. 397413, 2016.

- Nos caminhos da dupla consciência: América Latina, psicologia e descolonização. São Paulo, SP: Ed. do Autor, 2019.

SIQUEIRA, Gabriel Castro; DOS SANTOS, Alessandro de Oliveira. A felicidade segundo o povo guarani mbya: a noção de bem-viver. Acta Psicossomática, v. 1, n. 1, 2018.

SNELSON, Chareen L. Qualitative and mixed methods social media research: A review of the literature. International Journal of Qualitative Methods, v. 15, n. 1, 2016. doi:10.1177/1609406915624574. Acesso em: 01/08/2020.

SOUSA, Flaviana Rodrigues de. Povos indígenas e saúde mental: a luta pelo habitar sereno e confiado. 2018. Dissertação (Mestrado em Psicologia Experimental) - Instituto de Psicologia, Universidade de São Paulo, São Paulo, 2018. doi:10.11606/D.47.2018.tde-19072018-102952. Acesso em: 2020-05-04.

SOUZA SANTOS, Boaventura. Hablamos del socialismo del Buen Vivir. Camino socialista, v. 9, p. 4-7, 2010.

Cuando los excluidos tienen Derecho: justicia indígena, plurinacionalidad e interculturalidad. Justicia indígena, plurinacionalidad e interculturalidad en Ecuador, p. 13-50, 2012.

. La refundación del Estado en América Latina. Reinventar la izquierda en el siglo XXI: hacia un diálogo Norte-Sur, p. 281-297, 2014.

Para uma nova visão da Europa: aprender com o Sul. Sociologias, v. 18, n. 43, p. 24-56, 2016. 
TEIXEIRA, Lumena Celi. Aproximações da Psicologia à Saúde dos Povos Indígenas. Caderno Humaniza SUS, n. 5, 2015. Disponível em: http://bvsms.saude.gov.br/bvs/publicacoes/saude mental_volume 5.pdf. Acesso em: 02 mar. 2020.

TEIXEIRA FIQUER, Juliana. Bem-estar subjetivo: influência de variáveis pessoais e situacionais em auto-relato de afetos positivos e negativos. 2006. Dissertação (Mestrado em Psicologia Experimental) - Instituto de Psicologia, Universidade de São Paulo, São Paulo, 2006. doi:10.11606/D.47.2006.tde-14092006-175006. Acesso em: 2020-05-04.

TERENA, Naine. Audiovisual na Escola Terena Lutuma Dias: educação indígena diferenciada e as mídias. 2014. 203 f. Tese (Doutorado em Educação) - Pontifícia Universidade Católica de São Paulo, São Paulo, 2014.

TRICCO, Andrea et al. A scoping review on the conduct and reporting of scoping reviews. BMC medical research methodology, v. 16, n. 1, p. 15, 2016.

TRICCO, Andrea et al. PRISMA extension for scoping reviews (PRISMA-ScR): checklist and explanation. Annals of internal medicine, v. 169, n. 7, p. 467-473, 2018.

VEGA, Elisa. Descolonizar y despatriarcalizar para vivir bien. In: LANG, Mirian; MOKRANI, Dunia. Más allá de desarrollo. Quito: Abya Yala, 2011, pp. 257-64.

VITERI, Carlos. Súmak Káusai: Una respuesta viable al desarrollo. 2003. Trabalho de Conclusão do Curso (Licenciatura em Antropologia Aplicada) - Universidad Politécnica Salesiana del Ecuador, Quito, 2003.

WALSH, Catherine. Interculturalidad crítica/pedagogia de-colonial. Revista de Educação Técnica e Tecnológica em Ciências Agrícolas, v. 3, n. 6, p. 25-42, 2012.

WERÁ, Kaká. Quais são os termos corretos para se referir a povos indígenas? 2017. Vídeo. Disponível em: https://www.youtube.com/results? search query $=\mathrm{kaka}+$ wera +2017 . Acesso em: 02 mar. 2020. 


\section{APÊNDICES}

\section{Apêndice A - Teste piloto de extração de dados}

\begin{tabular}{|c|c|}
\hline \multicolumn{2}{|r|}{ Quadro analítico - 1} \\
\hline Autor & Saforcada, Enrique \\
\hline Ano de publicação & 2011 \\
\hline Título do estudo & Psicologia comunitaria y politica. En busca de lucidez \\
\hline Publicação & PSIENCIA. Revista Latinoamericana de Ciencia Psicológica \\
\hline Localização do estudo & Argentina \\
\hline Tipo de publicação & Artigo \\
\hline $\begin{array}{l}\text { População do estudo e tamanho da } \\
\text { amostra }\end{array}$ & - \\
\hline Tipo de intervenção & - \\
\hline Objetivos do estudo & $\begin{array}{l}\text { Análise sobre o contexto social, econômico e político da } \\
\text { Indoafroiberoamérica enquanto cenário concreto no qual ocorre a } \\
\text { vinculação da psicologia social e da sociedade. }\end{array}$ \\
\hline Método & Ensaio \\
\hline $\begin{array}{l}\text { Definição e fundamentação teórica } \\
\text { do projeto }\end{array}$ & $\begin{array}{l}\text { Reflexão sobre os efeitos psicossocioculturais do modo de } \\
\text { produção capitalista nos povos da Indoafroiberoamérica. Salienta } \\
\text { que praticamente todos os trabalhos da psicologia comunitária } \\
\text { nessa região implicam conglomerados humanos desprovidos de } \\
\text { bens e direitos básicos para uma vida digna e que para o } \\
\text { desenvolvimento de uma psicologia comunitária efetiva é } \\
\text { necessário que os profissionais reflitam sobre suas convicções, } \\
\text { preconceitos e compreensões da realidade em uma perspectiva } \\
\text { ética e histórica. }\end{array}$ \\
\hline $\begin{array}{l}\text { Conceitos e temas relacionados à } \\
\text { Psicologia }\end{array}$ & $\begin{array}{l}\text { Psicologia comunitária, efeitos psicossocioculturais, realização do } \\
\text { potencial humano }\end{array}$ \\
\hline Relação com o Bem Viver & $\begin{array}{l}\text { Emprega os modelos do Bem Viver da Bolívia e do Equador para } \\
\text { uma reflexão sobre modos de viver e organização social dos povos } \\
\text { que compõe a Indoafroiberoamérica. O autor defende que } \\
\text { profissionais da psicologia comunitária devem buscar formas de } \\
\text { trabalhar que considerem a cosmovisão dos grupos aos quais se }\end{array}$ \\
\hline
\end{tabular}




\begin{tabular}{|l|l|}
\hline & dediquem. \\
\hline Resultados & n.c. \\
\hline Agência financiadora. & - \\
\hline
\end{tabular}

\begin{tabular}{|c|c|}
\hline \multicolumn{2}{|r|}{ Quadro analítico - 2} \\
\hline Autor & Caria, Sara; Domínguez, Rafael \\
\hline Ano de publicação & 2014 \\
\hline Título do estudo & El porvenir de una ilusión: la ideología del Buen Vivir \\
\hline Publicação & América Latina Hoy \\
\hline Localização do estudo & Espanha \\
\hline Tipo de publicação & Artigo \\
\hline $\begin{array}{l}\text { População do estudo e tamanho da } \\
\text { amostra }\end{array}$ & - \\
\hline Tipo de intervenção & - \\
\hline Objetivos do estudo & $\begin{array}{l}\text { Analisar o conceito e as estratégias oficiais de Bem Viver no } \\
\text { Equador através do filtro das principais definições ideológicas das } \\
\text { tradições marxistas, psicanalítica e cognitiva, como falsa } \\
\text { consciência, programa mobilizador ou discurso hegemônico e } \\
\text { como um mecanismo cognitivo de redução de complexidade }\end{array}$ \\
\hline Método & Ensaio \\
\hline $\begin{array}{l}\text { Definição e fundamentação teórica } \\
\text { do projeto }\end{array}$ & $\begin{array}{l}\text { Análise de ideologia na perspectiva do materialismo histórico, da } \\
\text { psicanálise do enfoque cognitivo }\end{array}$ \\
\hline $\begin{array}{l}\text { Conceitos e temas relacionados à } \\
\text { Psicologia }\end{array}$ & Concepção psicoanalítica de ideologia \\
\hline Relação com o Bem Viver & $\begin{array}{l}\text { Segundo a autora o conceito de Bem Viver articulado pelo governo } \\
\text { de Rafael Correa se converteu em um instrumento discursivo } \\
\text { funcional para o Estado e sua estrutura com escasso significado } \\
\text { para transformação intercultural e plurinacional. }\end{array}$ \\
\hline Resultados & $\begin{array}{l}\text { Em suma as ações e planos governamentais executados pelo } \\
\text { governo Correa sob o discurso do Bem Viver na prática foi mais } \\
\text { uma abordagem desenvolvimentista. Logo o Bem Viver, nesse } \\
\text { contexto, se torna uma ideologia tanto quanto o desenvolvimento. }\end{array}$ \\
\hline
\end{tabular}


Agência financiadora.

Quadro analítico - 3

\begin{tabular}{|c|c|}
\hline Autor & Grondona-Opazo, Gino \\
\hline Ano de publicação & 2016 \\
\hline Título do estudo & $\begin{array}{l}\text { Psicología comunitaria y políticas sociales para el "buen vivir" en } \\
\text { ecuador }\end{array}$ \\
\hline Publicação & Interamerican Journal of Psychology \\
\hline Localização do estudo & Quito, Equador \\
\hline Tipo de publicação & Artigo \\
\hline $\begin{array}{l}\text { População do estudo e tamanho da } \\
\text { amostra }\end{array}$ & $\begin{array}{l}\text { Grupo 1: } 20 \text { mulheres pobres, idade de } 30 \text { a } 50 \text { anos, beneficiárias } \\
\text { do Programa de Transferência Condicionada "Bônus de } \\
\text { Desenvolvimento Humano". Grupo 2: } 10 \text { homens e } 10 \text { mulheres } \\
\text { pobres, idade de } 64 \text { a } 80 \text { anos, beneficiários do Programa de } \\
\text { Transferência Condicionada "Bônus de Desenvolvimento } \\
\text { Humano". } \\
\text { Grupo 3: jovens pobres, } 9 \text { homens e } 7 \text { mulheres, idade de } 15 \text { a } 20 \\
\text { anos Beneficiários do Programa "Actoría Juvenil" }\end{array}$ \\
\hline Tipo de intervenção & $\begin{array}{l}\text { Grupo de trabalho para construção da matriz de necessidades } \\
\text { humanas fundamentais (Max-Neef, 1994) }\end{array}$ \\
\hline Objetivos do estudo & $\begin{array}{l}\text { Apresentar os resultados da pesquisa "Discursos e práticas políticas } \\
\text { na sociedade equatoriana", realizada pelo Grupo de Pesquisa } \\
\text { Psicossocial da Universidade Politécnica Salesiana, no período } \\
\text { 2012-2013, cujo objetivo foi analisar as políticas sociais do Estado } \\
\text { equatoriano na perspectiva de sua coerência com os postulados do } \\
\text { Bem Viver, que moldam o projeto político da sociedade } \\
\text { equatoriana. }\end{array}$ \\
\hline Método & $\begin{array}{l}\text { Estratégia de triangulação metodológica, isto é, o uso de diferentes } \\
\text { instrumentos, fontes e participantes para proceder a análise de } \\
\text { determinado fenômeno social. A fonte de dados primários foi uma } \\
\text { matriz gerada através de três grupos distintos executando a } \\
\text { construção da matriz de necessidades humanas fundamentais } \\
\text { (Max-Neef, 1994). A fonte de dados secundária foi uma matriz } \\
\text { composta a partir de dados oficiais sobre as políticas de inclusão e } \\
\text { coesão social do Estado }\end{array}$ \\
\hline
\end{tabular}




\begin{tabular}{|l|l|}
\hline & $\begin{array}{l}\text { Equatoriano em vigor no período 2012-2013 (Coordenação do } \\
\text { Ministério do Desenvolvimento Social, 2012). }\end{array}$ \\
\hline $\begin{array}{l}\text { Definição e fundamentação teórica } \\
\text { do projeto }\end{array}$ & $\begin{array}{l}\text { Através do enfoque da psicologia social comunitária, produzir } \\
\text { conhecimento teórico e aplicado sobre os discursos e práticas } \\
\text { políticas presentes na sociedade equatoriana. }\end{array}$ \\
\hline Ponceitos e temas relacionados à & $\begin{array}{l}\text { Necessidades humanas fundamentais; coesão social; inclusão } \\
\text { social }\end{array}$ \\
\hline Relação com o Bem Viver & $\begin{array}{l}\text { A autora destaca a separação entre o conceito de Bem Viver } \\
\text { empregado pelo governo do Equador, enquanto marketing político, } \\
\text { e da noção de Sumak Kawsay (Bem Viver) indígena. Em suas } \\
\text { conclusões existe um desencontro em relação ao que o governo } \\
\text { prioriza como Bem Viver para populações de atenção prioritária e } \\
\text { as reais necessidades dessas populações. }\end{array}$ \\
\hline Resultados & $\begin{array}{l}\text { A autora conclui que as principais fontes de satisfação das } \\
\text { necessidades humanas fundamentais são relacionais e } \\
\text { comunitárias, destacando-se a família e a comunidade, bem como a } \\
\text { sociabilidade e as relações de reciprocidade e apoio mútuo. Ela } \\
\text { aponta a necessidade e relevância da Psicologia Comunitária para } \\
\text { articular e materializar políticas sociais de Bem Viver, com uma } \\
\text { abordagem territorial e orientada para a participação e } \\
\text { fortalecimento de comunidades. }\end{array}$ \\
\hline-
\end{tabular}

\begin{tabular}{|l|l|}
\hline \multicolumn{2}{|c|}{ Quadro analítico - 5 } \\
\hline Autor & Stumpf, Beatriz Osorio; Bergamaschi, Maria Aparecida \\
\hline Ano de publicação & 2016 \\
\hline Título do estudo & $\begin{array}{l}\text { Elementos espirituais, simbólicos e afetivos na construção da } \\
\text { escola mbyá guarani }\end{array}$ \\
\hline Publicação & Educação e Pesquisa \\
\hline Localização do estudo & Rio Grande do Sul, Brasil \\
\hline Tipo de publicação & Artigo \\
\hline $\begin{array}{l}\text { População do estudo e tamanho da } \\
\text { amostra }\end{array}$ & Aldeias Mbya Guarani, tamanho da amostra não foi especificado. \\
\hline Tipo de intervenção & - \\
\hline
\end{tabular}




\begin{tabular}{|c|c|}
\hline Objetivos do estudo & $\begin{array}{l}\text { Aprofundar reflexões sobre o processo de construção da escola a } \\
\text { partir de observações e convivências realizadas em aldeias mbyá } \\
\text { guarani do Rio Grande do Sul. }\end{array}$ \\
\hline Método & $\begin{array}{l}\text { Etnografia que registrou vivências, diálogos e } \\
\text { reflexões dentro e fora da escola, entre } 2011 \text { e } 2013 .\end{array}$ \\
\hline $\begin{array}{l}\text { Definição e fundamentação teórica } \\
\text { do projeto }\end{array}$ & $\begin{array}{l}\text { Historicamente a escola foi imposta aos povos indígenas, por vezes } \\
\text { de forma violenta. Porém, quando inserida ao cotidiano das aldeias } \\
\text { e conduzida de acordo com os preceitos de cada povo, em muitos } \\
\text { aspectos é apropriada por esses coletivos. No processo de } \\
\text { construção da escola específica, diferenciada e intercultural, o povo } \\
\text { mbyá guarani vive um momento de reflexão acerca dessa } \\
\text { instituição educativa. }\end{array}$ \\
\hline $\begin{array}{l}\text { Conceitos e temas relacionados à } \\
\text { Psicologia }\end{array}$ & $\begin{array}{l}\text { Intercultura, cultura, simbolismo, afetividade, sentimento, } \\
\text { aprendizagem. }\end{array}$ \\
\hline Resultados importantes & $\begin{array}{l}\text { A educação para o Bem viver, do paradigma indígena comunitário, } \\
\text { está fundamentada em uma concepção de mundo integradora e } \\
\text { complementária entre todos os seres, permitindo uma } \\
\text { aprendizagem relacionada com a plenitude da vida. Os resultados } \\
\text { desta pesquisa revelam a importância do diálogo no processo de } \\
\text { construção } \\
\text { da escola mbyá guarani com a educação comunitária do paradigma } \\
\text { do Bem viver, a partir de elementos como a visão ecológica, o } \\
\text { sentimento, a coletividade, a reciprocidade, a arte e o simbolismo, } \\
\text { que manifestaram sua relevância ao longo do trabalho. }\end{array}$ \\
\hline Agência financiadora. & - \\
\hline
\end{tabular}




\section{Apêndice B - Mapeamento de dados no quadro analítico}

\begin{tabular}{|c|c|c|c|c|c|c|}
\hline Ano & Autoria & Título & $\begin{array}{l}\text { Elementos do Bem Viver, características, articula- } \\
\text { ções }\end{array}$ & País & Tipo & Pulicação \\
\hline 2008 & $\begin{array}{l}\text { Silva, Fabio de } \\
\text { Oliveira Nogueira } \\
\text { da }\end{array}$ & $\begin{array}{l}\text { Elementos de etnografia Mbya: } \\
\text { lideranças e grupos familiares } \\
\text { na aldeia Tekoá Pyaú (Jaraguá- } \\
\text { São Paulo) }\end{array}$ & $\begin{array}{l}\text { Elementos marcantes: reciprocidade, evitação da vio- } \\
\text { lência, rituais cotidianos e a comunicação com as di- } \\
\text { vindades, cuidados alimentares e a relação com o meio } \\
\text { ambiente. compreensão de construções socioculturais. } \\
\text { O tekó (modo de ser) é frequentemente considerado "o } \\
\text { comportamento esperado" em determinadas situações. }\end{array}$ & Brasil & Tese & $\begin{array}{l}\text { Biblioteca Digital de } \\
\text { Teses e Dissertações da } \\
\text { USP }\end{array}$ \\
\hline 2011 & Albo, Xavier & $\begin{array}{l}\text { Suma qamaña = convivir bien. } \\
\text { ¿Cómo medirlo? }\end{array}$ & $\begin{array}{l}\text { O autor discute as possibilidades e necessidades de } \\
\text { índices específicos para mensurar o bem-estar em co- } \\
\text { munidades não ocidentais (ocidentalizadas), a partir de } \\
\text { questionamentos que emergem das noções de Bem Vi- } \\
\text { ver da América do Sul. }\end{array}$ & Bolívia & Artigo & $\begin{array}{l}\text { Vivir bien: ¿ Paradigma } \\
\text { no capitalista }\end{array}$ \\
\hline 2011 & $\begin{array}{l}\text { Chamorro, Graci- } \\
\text { ela }\end{array}$ & $\begin{array}{l}\text { O Bem viver nos povos indíge- } \\
\text { nas }\end{array}$ & $\begin{array}{l}\text { De acordo com a pesquisadora entre os Guarani atuais } \\
\text { as expressões teko katu e sua variante teko porã são os } \\
\text { marcadores constantes da identidade do grupo frente a } \\
\text { sociedade e religião circundantes. Os Kaiová e Pai- } \\
\text { Tavyterã se referem com elas a seus bons costumes, a } \\
\text { suas normas éticas tradicionais e ao sistema original } \\
\text { que orienta a vida dos seres divinos e divinizados. }\end{array}$ & Brasil & Artigo & $\begin{array}{l}\text { Revista Eletrônica His- } \\
\text { tória em Reflexão }\end{array}$ \\
\hline 2011 & $\begin{array}{l}\text { Saforcada, Enri- } \\
\text { que }\end{array}$ & $\begin{array}{l}\text { Psicologia comunitaria y politi- } \\
\text { ca. En busca de lucidez }\end{array}$ & $\begin{array}{l}\text { O autor discute o posicionamento da Psicologia face à } \\
\text { luta entre ricos e pobres no sistema capitalista, onde ri- } \\
\text { cos se organizam para manter a diferença. O autor } \\
\text { contrasta a mercantilização (no capitalismo) da educa- } \\
\text { ção, saúde, cultura e outras questões essenciais aos di- } \\
\text { reitos dos cidadãos com as propostas do Buen Vivir } \\
\text { andino. }\end{array}$ & Argentina & Artigo & $\begin{array}{l}\text { PSIENCIA. Revista } \\
\text { Latinoamericana de Ci- } \\
\text { encia Psicológica }\end{array}$ \\
\hline 2012 & $\begin{array}{l}\text { de Aguiar, Rodri- } \\
\text { go Luiz Simas; } \\
\text { Pereira, Levi }\end{array}$ & $\begin{array}{l}\text { Religion, duality of soul and } \\
\text { representations of Teko Porã in } \\
\text { Guarani peoples }\end{array}$ & $\begin{array}{l}\text { Para dois grupos Guarani, os Mbya e os Kayowá, a } \\
\text { vida cotidiana ainda hoje é organizada através de uma } \\
\text { dualidade da alma, uma oposição entre dois modelos }\end{array}$ & Brasil & Artigo & Anthropologica \\
\hline
\end{tabular}




\begin{tabular}{|c|c|c|c|c|c|c|}
\hline & Marques & & $\begin{array}{l}\text { de personalidade. O teko porã (bem viver) abrange } \\
\text { conteúdo que orienta o comportamento a partir de re- } \\
\text { presentações de um substrato mitológico, formando as- } \\
\text { sim algo similar a um ethos religioso. }\end{array}$ & & & \\
\hline 2012 & Loria, Gina & $\begin{array}{l}\text { Desarrollo de Estrategias para } \\
\text { Promover la Calidad de Vida y } \\
\text { el Vivir Bien aunadas al tema } \\
\text { de la Sustentabilidad en pobla- } \\
\text { ciones en situación de vulnera- } \\
\text { bilidad física y psicológica } \\
\text { como son las mujeres con Can- } \\
\text { cer }\end{array}$ & $\begin{array}{l}\text { O estudo apresenta a visão da Psicologia da Saúde em } \\
\text { relação a qualidade de vida de populações vulneráveis, } \\
\text { onde a autora contrasta conceitos de qualidade de vida } \\
\text { fundados no indivíduo com conceitos baseados no co- } \\
\text { letivo (Bem Viver). }\end{array}$ & Bolívia & Artigo & $\begin{array}{l}\text { Revista de Investigaci- } \\
\text { on Psicologica }\end{array}$ \\
\hline 2013 & $\begin{array}{l}\text { Vanhulst, Julien; } \\
\text { Beling, Adrian E }\end{array}$ & $\begin{array}{l}\text { El Buen vivir: una utopia lati- } \\
\text { noamericana en el campo dis- } \\
\text { cursivo global de la sustentabi- } \\
\text { lidad }\end{array}$ & $\begin{array}{l}\text { O Bem Viver como um modelo cultural emergendo } \\
\text { desde América Latina em resposta aos problemas civi- } \\
\text { lizatórios da vida coletiva. Esta crítica prima pela con- } \\
\text { sideração de modelos culturais marginalizados e pela } \\
\text { emergência de novas racionalidades excluídas pela } \\
\text { modernidade eurocêntrica dominante. Abordagem psi- } \\
\text { cológica sobre a sustentabilidade refletida na filosofia } \\
\text { andina do Bem Viver. }\end{array}$ & Chile & Artigo & Polis (Santiago) \\
\hline 2013 & Ehlers, Freddy & Buen Vivir TV & $\begin{array}{l}\text { O canal Buen Vivir TV foi uma ação da Secretaria del } \\
\text { Buen Vivir, inaugurado no segundo mandato de Rafael } \\
\text { Correal. É evidente no conjunto dos vídeos do canal } \\
\text { uma intenção didática de construir uma compreensão } \\
\text { do que seria Bem Viver. Há também uma certa cons- } \\
\text { trução filosófica, uma apologia a modos de vida sim- } \\
\text { ples, de viver bem com pouco em proximidade a natu- } \\
\text { reza, um tema muito frequente nos vídeos do canal. }\end{array}$ & Equador & Vídeo & Canal Buen Vivir TV \\
\hline
\end{tabular}




\begin{tabular}{|c|c|c|c|c|c|c|}
\hline 2013 & $\begin{array}{l}\text { Artaraz, Kepa; } \\
\text { Calestani, Mela- } \\
\text { nia }\end{array}$ & $\begin{array}{l}\text { Vivir bien, entre utopia y reali- } \\
\text { dad }\end{array}$ & $\begin{array}{l}\text { Examina a noção de bem-estar adotada recentemente } \\
\text { pela Constituição boliviana. Destacam-se as noções in- } \\
\text { dígenas de «viver bem», conceito que poderia ser tra- } \\
\text { duzido como «viver bem em grupo», sob os princípios } \\
\text { de sociabilidade e de promoção de valores de recipro- } \\
\text { cidade. Salienta que «viver bem» constitui um avanço } \\
\text { em nossas noções de bem-estar, pela ênfase que dão às } \\
\text { relações harmoniosas, não somente no que tange à so- } \\
\text { ciedade, mas também com relação à natureza (a Pacha- } \\
\text { mama - nossa Mãe terra), trazendo um nexo com a } \\
\text { sustentabilidade }\end{array}$ & Inglaterra & Artigo & Tabula Rasa \\
\hline 2013 & $\begin{array}{l}\text { Ascarrunz, Bea- } \\
\text { triz }\end{array}$ & $\begin{array}{l}\text { Nada bien le hace al ¿nuevo? } \\
\text { concepto del Vivir Bien, la } \\
\text { "idelalización" de los pueblos } \\
\text { indígenas }\end{array}$ & $\begin{array}{l}\text { A partir de um trabalho de campo com } 20 \text { povos indí- } \\
\text { genas em Bolívia, a autora discorre sobre sua hipótese } \\
\text { de conceber o Bem Viver como herdeiro de uma tradi- } \\
\text { ção intelectual de crítica a modernidade e a radical ho- } \\
\text { mogeneização cultural que a acompanha. A autora } \\
\text { aponta que não se pode aludir ao Bem Viver como um } \\
\text { conceito ancestral, pois conceitualizar não é uma práti- } \\
\text { ca dos povos originários, e nem uma prática da vida } \\
\text { cotidiana em geral, a produção de conceitos é uma } \\
\text { prática das ciências sociais. }\end{array}$ & Bolívia & Capítulo & $\begin{array}{l}\text { Universidad Mayor de } \\
\text { San Andrés - Bolívia }\end{array}$ \\
\hline 2014 & $\begin{array}{l}\text { Caria, Sara; Do- } \\
\text { minguez Martin, } \\
\text { Rafael }\end{array}$ & $\begin{array}{l}\text { El porvenir de una ilusión: la } \\
\text { ideología del Buen Vivir }\end{array}$ & $\begin{array}{l}\text { Analisa o conceito e as estratégias oficiais do Bem Vi- } \\
\text { ver através do filtro das principais definições de ideo- } \\
\text { logia das tradições marxistas, psicanalítica e cognitiva, } \\
\text { como falsa consciência, programa mobilizador ou dis- } \\
\text { curso hegemônico e como um mecanismo cognitivo de } \\
\text { redução de complexidade. }\end{array}$ & Espanha & Artigo & América Latina Hoy \\
\hline 2014 & $\begin{array}{l}\text { Caal, Cosme } \\
\text { Francisco }\end{array}$ & $\begin{array}{l}\text { The Pachamama worldview in } \\
\text { the Ecuadorian urban ayllu net- } \\
\text { work: Mashi identity and resist- } \\
\text { ance in early } 21 \text { st-century } \\
\text { Quito }\end{array}$ & $\begin{array}{l}\text { Postula que a compreensão da prática contemporânea } \\
\text { do sumak kawsay deve ocorrer através da compreen- } \\
\text { são da identidade indígena equatoriana e de sua mobi- } \\
\text { lização política no século XXI. No presente, o sumak } \\
\text { kawsay fornece apoio político, espiritual e econômico } \\
\text { para as comunidades familiares (ayllus) que, de outra } \\
\text { forma, têm pouco ou nenhum apoio do governo. }\end{array}$ & Equador & Tese & $\begin{array}{l}\text { University of Califor- } \\
\text { nia, Santa Barbara }\end{array}$ \\
\hline
\end{tabular}




\begin{tabular}{|c|c|c|c|c|c|c|}
\hline 2014 & $\begin{array}{l}\text { Ramírez Hita, Su- } \\
\text { sana }\end{array}$ & $\begin{array}{l}\text { Aspectos interculturales de la } \\
\text { reforma del sistema de salud en } \\
\text { Bolivia }\end{array}$ & $\begin{array}{l}\text { Crítica sobre como a interculturalidade, presente no } \\
\text { conceito de Bem Viver, não está contribuindo para a } \\
\text { melhoria da qualidade de vida e saúde das populações } \\
\text { mais vulneráveis da Bolívia. O discurso do Bem Viver } \\
\text { está ligado à intenção de salvar a vida em seu sentido } \\
\text { mais amplo, para isso seria necessário que tomadas de } \\
\text { decisão sobre saúde ambiental e política extrativista } \\
\text { considerassem os problemas de saúde que afetam os } \\
\text { povos indígenas. }\end{array}$ & Bolívia & Artigo & $\begin{array}{l}\text { Revista Peruana de } \\
\text { Medicina Experimental } \\
\text { y Salud Pública }\end{array}$ \\
\hline 2014 & $\begin{array}{l}\text { Condori, Porfidio } \\
\text { Tintaya }\end{array}$ & $\begin{array}{l}\text { Sentido de convivencia y cons- } \\
\text { trucción de saberes válidos }\end{array}$ & $\begin{array}{l}\text { O artigo discorre sobre o suma qamaña (viver bem) } \\
\text { como condição formativa que regula a convivência na } \\
\text { comunidade, as relações interpessoais, as atividades } \\
\text { produtivas e os processos de compreensão e interven- } \\
\text { ção. Aborda-se o sentido de viver bem como pressu- } \\
\text { posto que orienta a construção de saberes válidos, ou } \\
\text { seja, de conhecimentos que realmente sustentam a vida } \\
\text { da comunidade }\end{array}$ & Bolívia & Artigo & $\begin{array}{l}\text { Revista Investigacion } \\
\text { Psicologica }\end{array}$ \\
\hline 2014 & $\begin{array}{l}\text { Tortosa-Martinez, } \\
\text { Juan; Caus-Perte- } \\
\text { gaz, Nuria; Asun- } \\
\text { cion Martinez- } \\
\text { Roman, Maria }\end{array}$ & $\begin{array}{l}\text { Vida Triste and Buen Vivir ac- } \\
\text { cording to older adults in Ota- } \\
\text { valo, Ecuador }\end{array}$ & $\begin{array}{l}\text { O estudo avalia políticas de atenção e intervenções de- } \\
\text { correntes do Plano Nacional para o Bem Viver do Es- } \\
\text { tado equatoriano (2009-2013) junto à pessoas adultas } \\
\text { maiores, através de diagnósticos de suas condições } \\
\text { físicas e psicológicas. Dentre as conclusões destaca-se } \\
\text { a importância de considerar as opiniões dos beneficiá- } \\
\text { rios, suas próprias avaliações de possíveis melhorias } \\
\text { em suas condições de vida e a concepções subjetivas } \\
\text { de Bem Viver. Esta metodologia qualitativa fornece } \\
\text { uma nova perspectiva no desenho de indicadores de } \\
\text { Bem Viver. }\end{array}$ & Equador & Artigo & $\begin{array}{l}\text { Convergencia Revista } \\
\text { de Ciencias Sociales }\end{array}$ \\
\hline 2014 & Walsh, Catherine & $\begin{array}{l}\text { Pedagogías decoloniales cami- } \\
\text { nando y preguntando. Notas a } \\
\text { Paulo Freire desde Abya Yala }\end{array}$ & $\begin{array}{l}\text { Catherine Walsh em um diálogo com Paulo Freire, de- } \\
\text { safia e coloca em tensão suas propostas à luz de uma } \\
\text { (re) existência descolonial que impõe e exige a con- } \\
\text { cepção de outras pedagogias, próximas a freiriana no } \\
\text { sentido revolucionário, porém diferentes pelo seu dis- } \\
\text { tanciamento da modernidade ocidental e de suas op- }\end{array}$ & Equador & Artigo & $\begin{array}{l}\text { Revista Entramados - } \\
\text { Educación y Sociedad }\end{array}$ \\
\hline
\end{tabular}




\begin{tabular}{|c|c|c|c|c|c|c|}
\hline & & & $\begin{array}{l}\text { ções epistemológicas Eurocêntricas. Walsh discorre } \\
\text { sobre pedagogias baseadas em modos de viver de po- } \\
\text { vos originários, como o Bem Viver dos povos andinos. }\end{array}$ & & & \\
\hline 2014 & Lajo, Javier & Canal Javier Lajo & $\begin{array}{l}\text { Lajo é um dos intelectuais indígenas peruanos que } \\
\text { mais publica sobre as noções de Bem Viver. Lajo argu- } \\
\text { menta que o equilíbrio pleno para o Sumaq Kawsay é } \\
\text { produto do equilíbrio entre sentir e pensar, o que inci- } \\
\text { de num "agir pleno", equilibrado e consequente, no } \\
\text { qual o critério de verdade é a consciência plena do mo- } \\
\text { mento e a própria circunstância do Sumaq Kawsay } \\
\text { (existência esplêndida) }\end{array}$ & Peru & Vídeo & Canal Javier Lajo \\
\hline 2015 & $\begin{array}{l}\text { Meliá, Bartolo- } \\
\text { meu }\end{array}$ & El buen vivir se aprende & $\begin{array}{l}\text { Meliá discute aspectos místicos e religiosos, de perten- } \\
\text { cimento e de reciprocidade, enquanto experiência de } \\
\text { vida compartilhada e convivência pacífica. Segundo o } \\
\text { autor, o teko porá é formado por vários aspectos, den- } \\
\text { tre os quais destaca-se o tekó marangatu: o modo de } \\
\text { ser religioso expressado mediante as palavras dos mi- } \\
\text { tos e dos relatos exemplares. }\end{array}$ & Brasil & Artigo & $\begin{array}{l}\text { Revista Electrónica de } \\
\text { Educación Sinéctica }\end{array}$ \\
\hline 2015 & $\begin{array}{l}\text { Ruiz-Eslava, Lui- } \\
\text { sa Fernanda }\end{array}$ & $\begin{array}{l}\text { Salud mental en tiempos de } \\
\text { guerra, una reflexión sobre la } \\
\text { relación conflicto armado-salud } \\
\text { mental en la comunidad indíge- } \\
\text { na Emberá en situación de des- } \\
\text { plazamiento forzado }\end{array}$ & $\begin{array}{l}\text { O conflito armado foi entendido como um mecanismo } \\
\text { que força a população indígena Emberá a passar por } \\
\text { cenários desconhecidos e violentos, que juntos afetam } \\
\text { o bem-estar, o seu modo de viver (Bem Viver), suas } \\
\text { condições e qualidade de vida. Atualmente, não há in- } \\
\text { tervenções em saúde mental culturalmente apropriadas } \\
\text { e coerentes com as necessidades da população indíge- } \\
\text { na Emberá. Conclui-se que é necessário garantir seu } \\
\text { acesso ao território - e exercício do poder nesse espaço } \\
\text { - para que possam trabalhar e viver em comunidade, } \\
\text { de acordo com seus próprios modos de existir (Bem } \\
\text { Viver). }\end{array}$ & Colômbia & Artigo & $\begin{array}{l}\text { Revista de la Facultad } \\
\text { de Medicina }\end{array}$ \\
\hline 2015 & $\begin{array}{l}\text { Collin Harguinde- } \\
\text { guy, Laura }\end{array}$ & $\begin{array}{l}\text { De la identidad folclórica a la } \\
\text { reivindicación del buen vivir }\end{array}$ & $\begin{array}{l}\text { O autor argumenta sobre a necessidade de superar a vi- } \\
\text { são folclórica de cultura e identidade, para avançar em } \\
\text { direção a revalorização de lógicas implícitas, tal como } \\
\text { proposto nas filosofias do Bem Viver (conceito social }\end{array}$ & México & Artigo & $\begin{array}{l}\text { Revista pueblos y fron- } \\
\text { teras digital }\end{array}$ \\
\hline
\end{tabular}




\begin{tabular}{|c|c|c|c|c|c|c|}
\hline & & & e político). & & & \\
\hline 2015 & $\begin{array}{l}\text { Molina Bedoya, } \\
\text { Victor Alonso }\end{array}$ & $\begin{array}{l}\text { Existencia equilibrada. Metáfo- } \\
\text { ra del Buen Vivir de los pue- } \\
\text { blos indígenas }\end{array}$ & $\begin{array}{l}\text { Em pesquisa realizada na comunidade indígena Nasa } \\
\text { de Colômbia se descobriu que as categorias: existência } \\
\text { equilibrada, território e economia da reciprocidade } \\
\text { funcionam como um eixo integrador dos estilos de } \\
\text { vida da comunidade. A economia indígena aponta para } \\
\text { o autoconsumo e a autosubsistência; é uma economia } \\
\text { da solidariedade realizada coletivamente para o benefí- } \\
\text { cio de todos o que coloca no centro da sua atenção aos } \\
\text { seres humanos e não as mercadorias. Discute-se a co- } \\
\text { nexão com o Bem Viver de muitas das nossas culturas } \\
\text { americanas que resistem ao modelo produtivista que } \\
\text { prevalece em escala mundial. }\end{array}$ & Colômbia & Artigo & Polis (Santiago) \\
\hline 2015 & $\begin{array}{l}\text { Carrasco, Morita; } \\
\text { Ramirez, Silvina }\end{array}$ & $\begin{array}{l}\text { Somos un pueblo, precisamos } \\
\text { un territorio porque allí es don- } \\
\text { de se da la vida indígena; sin } \\
\text { territorio no hay identidad } \\
\text { como pueblo. Buen vivir en Ar- } \\
\text { gentina }\end{array}$ & $\begin{array}{l}\text { De uma perspectiva interdisciplinar que articula posi- } \\
\text { ções do direito, psicologia e antropologia, o artigo } \\
\text { propõe uma análise de alguns pronunciamentos e do- } \\
\text { cumentos de povos indígenas na Argentina para enten- } \\
\text { der o significado que eles dão para o Bem Viver, sem } \\
\text { nomeá-lo desta maneira. Os indígenas da Argentina es- } \\
\text { tão começando a enunciar suas reivindicações pela } \\
\text { perspectiva do Bem Viver, entendido como um concei- } \\
\text { to filosófico, embora como projeto político tenha esta- } \\
\text { do sempre presente em suas formulações. }\end{array}$ & Argentina & Artigo & $\begin{array}{l}\text { Revista pueblos y fron- } \\
\text { teras digital }\end{array}$ \\
\hline 2015 & Rozas, German & $\begin{array}{l}\text { Hacia una Psicología Social } \\
\text { Comunitaria del Sur }\end{array}$ & $\begin{array}{l}\text { Na América Latina, considerando-se os movimentos } \\
\text { sociais relacionados a comunidades indígenas, afro- } \\
\text { descendentes e outras, a psicologia deve ser reconfigu- } \\
\text { rada qualitativamente para dar conta dessas realidades. } \\
\text { Discute-se o sentido de desconstruir a colonização do } \\
\text { conhecimento e de aprofundar a interpretação da reali- } \\
\text { dade que faz cada comunidade a partir de suas particu- } \\
\text { laridades e cosmovisões. O autor argumenta que deve- } \\
\text { se enfatizar um tipo de transformação social voltada } \\
\text { para a construção de outra epistemologia, que incorpo- } \\
\text { ra a interculturalidade, a plurinacionalidade, os direitos }\end{array}$ & Chile & Artigo & $\begin{array}{l}\text { Revista Psicología, Co- } \\
\text { nocimiento y Sociedad }\end{array}$ \\
\hline
\end{tabular}




\begin{tabular}{|c|c|c|c|c|c|c|}
\hline & & & coletivos e o Bem Viver. & & & \\
\hline 2015 & $\begin{array}{l}\text { Caro, Leyla M.; } \\
\text { Varas, Pablo R. }\end{array}$ & $\begin{array}{l}\text { Principios orientadores en la in- } \\
\text { tervención psicosocial y comu- } \\
\text { nitaria centrada en infancia, in- } \\
\text { terculturalidad y Buen Vivir }\end{array}$ & $\begin{array}{l}\text { Este artigo apresenta uma experiência de intervenção } \\
\text { psicossocial e comunitária realizada num espaço de } \\
\text { educação não formal chamado Escolinha intercultural } \\
\text { para o Buen Vivir em Antofagasta, Chile. O principal } \\
\text { objetivo foi o de contribuir para a reflexão sobre os } \\
\text { princípios orientadores dentro da intervenção psicosso- } \\
\text { cial e comunitária, e simultaneamente, analisar o seu } \\
\text { potencial como modelo ou matriz de trabalho em in- } \\
\text { fância, interculturalidade e Buen Vivir. }\end{array}$ & Chile & Artigo & Polis (Santiago) \\
\hline 2015 & $\begin{array}{l}\text { Cabrales Salazar, } \\
\text { Omar }\end{array}$ & $\begin{array}{l}\text { El principo del buen vivir o Su- } \\
\text { mak Kawsay como fundamento } \\
\text { para el decrecimiento económi- } \\
\text { co }\end{array}$ & $\begin{array}{l}\text { O autor argumenta sobre a necessidade de implemen- } \\
\text { tar outros modelos ou ideais de vida e de progresso por } \\
\text { causa do dano ambiental e social gerado pela explora- } \\
\text { ção dos recursos naturais nos países latino-americanos } \\
\text { durante o período do neoliberalismo. Aludindo ao o } \\
\text { fim da Modernidade, ele discute a ideia de progresso } \\
\text { ocidental face ao surgimento de outros ideais e estilos } \\
\text { de vida. Finalmente, ele apresenta as razões para mu- } \\
\text { danças do modelo civilizatório, citando a redução vo- } \\
\text { luntária do consumo e o decrescimento econômico } \\
\text { como alternativas de desenvolvimento, baseado na } \\
\text { cosmovisão ancestral kichwa do Bem Viver. }\end{array}$ & Equador & Artigo & $\begin{array}{l}\text { Cuadernos de Filosofia } \\
\text { Latinoamericana }\end{array}$ \\
\hline 2015 & $\begin{array}{l}\text { Mina Rojas, Cha- } \\
\text { ro; Machado } \\
\text { Montero, Ma- } \\
\text { rilyn; Botero, Pa- } \\
\text { tricia M; Escobar, } \\
\text { Arturo }\end{array}$ & $\begin{array}{l}\text { Luchas del buen vivir por las } \\
\text { mujeres negras del Alto Cauca }\end{array}$ & $\begin{array}{l}\text { O texto traça a genealogia do Bem Viver negro como } \\
\text { forma de rastrear silenciamentos, resistências, tipos de } \\
\text { reexistência e emergências nas lutas do povo negro na } \\
\text { Colômbia. Tais existências promovem novas formas } \\
\text { de vida e política, apontando simetrias e sincretismo } \\
\text { entre Ubuntu e Bem Viver Andino. Aborda a Mobiliza- } \\
\text { ção de Mulheres Afrodescendentes pelo Cuidado da } \\
\text { Vida e os Territórios Ancestrais, e reconta a história } \\
\text { viva dos vínculos existentes entre ancestralidade e fu- } \\
\text { turidade. }\end{array}$ & Colômbia & Artigo & Nomadas (Colombia) \\
\hline 2015 & $\begin{array}{l}\text { Gomez, Patricia } \\
\text { Botero }\end{array}$ & $\begin{array}{l}\text { Subjetividades colectivas y } \\
\text { prácticas de paz en contextos }\end{array}$ & $\begin{array}{l}\text { A autora problematiza a noção de desenvolvimento hu- } \\
\text { mano a partir da psicologia política decolonial. Ela }\end{array}$ & Colômbia & Artigo & $\begin{array}{l}\text { Prospectiva: Revista de } \\
\text { Trabajo Social e Inter- }\end{array}$ \\
\hline
\end{tabular}




\begin{tabular}{|c|c|c|c|c|c|c|}
\hline & & $\begin{array}{l}\text { de guerra. Una perspectiva des- } \\
\text { de la psicología política decolo- } \\
\text { nial }\end{array}$ & $\begin{array}{l}\text { discorre sobre comunidades em contexto de guerra na } \\
\text { Colômbia que empregam formas de resistências ances- } \\
\text { trais e através delas propõem a noção de subjetivida- } \\
\text { des coletivas, a partir de suas filosofias plurais de Bem } \\
\text { Viver. Trata-se de uma revolução paradigmática e uma } \\
\text { transição civilizatória com implicações políticas para } \\
\text { lidar com os conflitos armados na Colômbia. }\end{array}$ & & & vencion Social \\
\hline 2015 & $\begin{array}{l}\text { Barreno Salinas, } \\
\text { Zoila; Macias Al- } \\
\text { varado, Jessica }\end{array}$ & $\begin{array}{l}\text { Estimulación temprana para po- } \\
\text { tenciar la inteligencia psicomo- } \\
\text { triz: importancia y relación }\end{array}$ & $\begin{array}{l}\text { Considerada a importância do desenvolvimento inte- } \\
\text { gral infantil e a estimulação das capacidades na Cons- } \\
\text { tituição de } 2008 \text { do Plano Nacional do Buen Vivir } \\
\text { 2013-2017 do Equador, o estudo aborda o desenvolvi- } \\
\text { mento infantil integral, através de várias ações, com } \\
\text { compromissos e responsabilidades do Estado e da fa- } \\
\text { mília. }\end{array}$ & Equador & Artigo & $\begin{array}{l}\text { Revista Ciencia UNE- } \\
\text { MI }\end{array}$ \\
\hline 2015 & $\begin{array}{l}\text { Articulação de } \\
\text { Mulheres Negras } \\
\text { Brasileiras }\end{array}$ & $\begin{array}{l}\text { Manifesto da Marcha } \\
\text { das Mulheres Negras Contra o } \\
\text { Racismo, a Violência } \\
\text { e Pelo Bem Viver de } 2015 \text { em } \\
\text { Brasília }\end{array}$ & $\begin{array}{l}\text { O manifesto documenta as principais demandas da } \\
\text { Marcha Nacional das Mulheres Negras de } 2015 \text { Contra } \\
\text { o Racismo, a Violência e pelo Bem Viver: O Bem Vi- } \\
\text { ver Como Nova Utopia". Este movimento foi o resul- } \\
\text { tado de mais de três anos de articulação de organiza- } \\
\text { ções da sociedade civil ligadas às mulheres negras. A } \\
\text { "Marcha" mobilizou cerca de } 50 \text { mil pessoas em Bra- } \\
\text { sília e reivindicava equidade, solidariedade e bem- } \\
\text { estar como valores inegociáveis e que devem ser mo- } \\
\text { nitorados com base em indicadores tais como o bem- } \\
\text { estar psicológico, a saúde, o uso do tempo, a educação, } \\
\text { a cultura e o padrão de vida, }\end{array}$ & Brasil & Manifesto & $\begin{array}{l}\text { Articulação de Organi- } \\
\text { zações de Mulheres } \\
\text { Negras Brasileiras }\end{array}$ \\
\hline 2016 & $\begin{array}{l}\text { Gomez-Restrepo, } \\
\text { Carlos; Rincon, } \\
\text { Carlos Javier; Ur- } \\
\text { rego-Mendoza, } \\
\text { Zulma }\end{array}$ & $\begin{array}{l}\text { Salud mental, sufrimiento emo- } \\
\text { cional, problemas y trastornos } \\
\text { mentales de indígenas colombi- } \\
\text { anos. Datos de la Encuesta Na- } \\
\text { cional de Salud Mental } 2015\end{array}$ & $\begin{array}{l}\text { Em estudos populacionais, verificou-se que as taxas de } \\
\text { problemas e distúrbios mentais dos povos indígenas } \\
\text { são geralmente mais altas do que as dos não-indígenas } \\
\text { que vivem nas mesmas áreas. É o produto das diferen- } \\
\text { ças socioeconômicas, da má qualidade de vida, da de- } \\
\text { terioração do tecido social, cultural e familiar e da vio- } \\
\text { lência. Os povos indígenas conceituam a saúde mental } \\
\text { de forma holística, contextual, ligada ao território, ao }\end{array}$ & Colômbia & Artigo & $\begin{array}{l}\text { Revista Colombiana de } \\
\text { Psiquiatria }\end{array}$ \\
\hline
\end{tabular}




\begin{tabular}{|c|c|c|c|c|c|c|}
\hline & & & $\begin{array}{l}\text { bem-estar coletivo e à harmonia com a Mãe Natureza. } \\
\text { Além disso, entre os povos indígenas colombianos, o } \\
\text { conceito de saúde é abrangente e comparável ao de um } \\
\text { Buen Vivir, sem distinções entre físico e mental. }\end{array}$ & & & \\
\hline 2016 & $\begin{array}{l}\text { Stumpf, Beatriz } \\
\text { Osorio; Berga- } \\
\text { maschi, Maria } \\
\text { Aparecida }\end{array}$ & $\begin{array}{l}\text { Elementos espirituais, simbóli- } \\
\text { cos e afetivos na construção da } \\
\text { escola mbyá guarani }\end{array}$ & $\begin{array}{l}\text { Investigação etnográfica que registrou vivências, diá- } \\
\text { logos e reflexões dentro e fora da escola. Foram obser- } \\
\text { vadas as dimensões da espiritualidade e da afetividade } \\
\text { na aprendizagem cognitiva, no desenvolvimento de ha- } \\
\text { bilidades e na internalização de valores presentes no } \\
\text { paradigma comunitário do Bem Viver. }\end{array}$ & Brasil & Artigo & Educação e Pesquisa \\
\hline 2016 & $\begin{array}{l}\text { Grondona-Opazo, } \\
\text { Gino }\end{array}$ & $\begin{array}{l}\text { Psicología Comunitaria y Po- } \\
\text { líticas Sociales para el "Buen } \\
\text { Vivir" em Ecuador }\end{array}$ & $\begin{array}{l}\text { O autor discorre sobre o debate en torno da conceitua- } \\
\text { lização do Bem Viver. Ele alega que o Bem Viver é } \\
\text { operado como um discurso mistificador do mundo an- } \\
\text { dino indígena, e seria, portanto, mais perto de um dis- } \\
\text { curso ideológico ou marketing político, do que uma } \\
\text { proposta transformadora No entanto, é reconhecido e } \\
\text { valorizado o fato de que estes debates colocam em } \\
\text { questão as formas e conteúdos dos projetos de desen- } \\
\text { volvimento, reiterando a necessidade de incluir aspec- } \\
\text { tos que reflitam cosmovisões dos povos originários } \\
\text { nos projetos políticos e sociais dos países da América } \\
\text { do Sul }\end{array}$ & Equador & Artigo & $\begin{array}{l}\text { Interamerican Journal } \\
\text { of Psychology }\end{array}$ \\
\hline 2016 & $\begin{array}{l}\text { Santos, Boaventu- } \\
\text { ra de Sousa }\end{array}$ & $\begin{array}{l}\text { Para uma nova visão da Euro- } \\
\text { pa: aprender com o Sul }\end{array}$ & $\begin{array}{l}\text { O autor discute a interculturalidade como uma via de } \\
\text { acesso à dignidade humana, a partir da premissa que } \\
\text { "temos o direito a ser iguais quando a diferença nos in- } \\
\text { ferioriza, temos o direito a ser diferentes quando a } \\
\text { igualdade nos descaracteriza". Ele frisa a importância } \\
\text { do conhecimento dos povos originários, das epistemo- } \\
\text { logias do sul, tanto para o resgate da dignidade huma- } \\
\text { na quanto para a continuidade da vida no planeta, su- } \\
\text { gerindo que "a defesa da interculturalidade e dos direi- } \\
\text { tos humanos é cada vez mais a mesma luta". No pris- } \\
\text { ma do Bem Viver, o autor apresenta como exemplo } \\
\text { concreto de diálogo intercultural os direitos da nature- }\end{array}$ & Portugal & Artigo & Revista Sociologias \\
\hline
\end{tabular}




\begin{tabular}{|c|c|c|c|c|c|c|}
\hline & & & za plasmados na Constituição do Equador de 2008. & & & \\
\hline 2016 & $\begin{array}{l}\text { Irigaray, C.T.J.H.; } \\
\text { Girard, P.; Iriga- } \\
\text { ray, M.; da Silva, } \\
\text { C.J. }\end{array}$ & $\begin{array}{l}\text { Ayahuasca and Sumak Kawsay: } \\
\text { Challenges to the Implementa- } \\
\text { tion of the Principle of Buen } \\
\text { Vivir. Religious Freedom, and } \\
\text { Cultural Heritage Protection }\end{array}$ & $\begin{array}{l}\text { Os autores afirmam que alternativas de transcendência } \\
\text { humana são identificadas na civilização inca para com- } \\
\text { pensar o mal-estar que caracteriza a crise ambiental } \\
\text { (crise civilizatória) dos dias atuais. Há uma dimensão } \\
\text { multicultural nas manifestações da Hoasca (ou Ayahu- } \\
\text { asca) que ocorrem nos países amazônicos, como parte } \\
\text { de uma herança cultural compartilhada. Os autores } \\
\text { postulam que, quando usado em contexto religioso, } \\
\text { Hoasca pode contribuir para a reconstrução de Buen } \\
\text { Vivir (ou em quíchua, sumak kawsay), que serviu } \\
\text { como princípio das civilizações que precederam a co- } \\
\text { lonização das Américas pelos europeus. }\end{array}$ & Brasil & Artigo & $\begin{array}{l}\text { Anthropology of Cons- } \\
\text { ciousness }\end{array}$ \\
\hline 2016 & $\begin{array}{l}\text { Burgos Ayala, } \\
\text { Aracely }\end{array}$ & $\begin{array}{l}\text { Buen vivir con la naturaleza en } \\
\text { las instituciones educativas: } \\
\text { una necesidad en Boyacá, Co- } \\
\text { lombia }\end{array}$ & $\begin{array}{l}\text { A autora argumenta que o atual modelo de desenvolvi- } \\
\text { mento econômico conseguiu desequilibrar a relação } \\
\text { entre os seres humanos e os outros seres da natureza. } \\
\text { Possibilidades de mitigação desse desequilíbrio são } \\
\text { discutidas através do desenvolvimento de práticas de } \\
\text { Buen Vivir em duas de suas variáveis e dimensões de- } \\
\text { rivadas: direitos humanos (educação e participação) e } \\
\text { direitos da natureza (respeito, proteção e restauração) } \\
\text { nas instituições de ensino. }\end{array}$ & Colômbia & Artigo & Culturales \\
\hline 2016 & $\begin{array}{l}\text { Sanchez Cabezas, } \\
\text { Patricia del Pilar; } \\
\text { Gonzalez Valare- } \\
\text { zo, Miguel; Zum- } \\
\text { ba Vera, Ingrid } \\
\text { Yolanda }\end{array}$ & $\begin{array}{l}\text { El psicólogo educativo y su res- } \\
\text { ponsabilidad en la sociedad } \\
\text { ecuatoriana actual: compromi- } \\
\text { sos, retos y desafios de la edu- } \\
\text { cación del siglo XXI }\end{array}$ & $\begin{array}{l}\text { Mudanças na sociedade equatoriana nos últimos anos } \\
\text { já alteraram a demanda e o papel da psicologia educa- } \\
\text { cional, especialmente com base nos objetivos do Plano } \\
\text { Nacional do Bem Viver. Este trabalho tem como obje- } \\
\text { tivo ajudar a identificar sinergias que caracterizam os } \\
\text { antigos e novos compromissos sociais desse profissio- } \\
\text { nal. Para tanto, são sistematizadas as posições teóricas } \\
\text { confrontadas com os resultados de pesquisas, entrevis- } \\
\text { tas, grupos de discussão com psicólogos educacionais. } \\
\text { Os resultados permitem desvendar compromissos des- } \\
\text { sa atividade profissional no Equador, também dão à } \\
\text { universidade a responsabilidade de desenvolver pro- }\end{array}$ & Equador & Artigo & $\begin{array}{l}\text { Revista Universidad y } \\
\text { Sociedad }\end{array}$ \\
\hline
\end{tabular}




\begin{tabular}{|c|c|c|c|c|c|c|}
\hline & & & $\begin{array}{l}\text { postas que permitam avaliar a qualidade das interven- } \\
\text { ções. }\end{array}$ & & & \\
\hline 2016 & $\begin{array}{l}\text { Conselho Regio- } \\
\text { nal de Psicologia } \\
\text { de São Paulo }\end{array}$ & $\begin{array}{l}\text { Povos indígenas e psicologia: a } \\
\text { procura do bem viver }\end{array}$ & $\begin{array}{l}\text { Ação do CRP visando avançar a construção da psico- } \\
\text { logia crítica brasileira, comprometida com a justiça so- } \\
\text { cial e a questão da condição das populações indígenas } \\
\text { no Brasil. O etnocídio insiste em destruir traços pró- } \\
\text { prios das culturas desses povos, sob a forma, sobretu- } \\
\text { do, do estabelecimento de padrões de moralidade a } \\
\text { partir da valorização das culturas dos povos dos países } \\
\text { dominantes. Tais processes produzem afetos, sofri- } \\
\text { mentos, medos, utopias e desejos que uma psicologia } \\
\text { brasileira necessita abraçar. Ação que visa contribuir } \\
\text { com as lutas pela dignidade, lutas pelo bem viver des- } \\
\text { ses povos, através de novas teorias, perspectivas de } \\
\text { análise da dimensão subjetiva apoiadas em seus sabe- } \\
\text { res e suas cosmovisões. }\end{array}$ & Brasil & Livro & $\begin{array}{l}\text { Portal do Conselho Re- } \\
\text { gional de Psicologia de } \\
\text { São Paulo }\end{array}$ \\
\hline 2016 & $\begin{array}{l}\text { Macena, Pedro } \\
\text { Luiz }\end{array}$ & $\begin{array}{l}\text { O tempo da criança e da nature- } \\
\text { za na educação diferenciada } \\
\text { guarani }\end{array}$ & $\begin{array}{l}\text { O intelectual discorre sobre as especificidades da } \\
\text { transmissão de conhecimento e noções de educação e } \\
\text { Bem Viver em sua comunidade Mbya Guarani, em Ja- } \\
\text { ragúa, SP. }\end{array}$ & Brasil & Capítulo & $\begin{array}{l}\text { Portal do Conselho Re- } \\
\text { gional de Psicologia de } \\
\text { São Paulo }\end{array}$ \\
\hline 2016 & Teixeira, Lumena & $\begin{array}{l}\text { A psicologia na promoção do } \\
\text { bem viver indígena }\end{array}$ & $\begin{array}{l}\text { Partindo de demandas formuladas por indígenas a psi- } \\
\text { cólogos, no campo da saúde mental, busca articulá-las } \\
\text { a referências na psicologia e nas políticas públicas ofi- } \\
\text { ciais, apontando para uma perspectiva emancipatória. } \\
\text { Aborda sobre a gênese do sofrimento psíquico, a no- } \\
\text { ção de bem viver e o modelo psicossocial, concluindo }\end{array}$ & Brasil & Capítulo & $\begin{array}{l}\text { Portal do Conselho Re- } \\
\text { gional de Psicologia de } \\
\text { São Paulo }\end{array}$ \\
\hline
\end{tabular}




\begin{tabular}{|c|c|c|c|c|c|c|}
\hline & & & $\begin{array}{l}\text { com algumas proposições da Psicologia Social Comu- } \\
\text { nitária e Psicologia da Libertação. }\end{array}$ & & & \\
\hline 2016 & $\begin{array}{l}\text { Conselho Indige- } \\
\text { nista Missionário }\end{array}$ & Bem Viver - um novo caminho & $\begin{array}{l}\text { O documentário do CIMI reúne vozes de lideranças e } \\
\text { intelectuais indígenas, intelectuais indigenistas e vo- } \\
\text { luntários do CIMI para refletir sobre suas percepções e } \\
\text { vivências em torno das ideias de Bem Viver. }\end{array}$ & Brasil & Vídeo & $\begin{array}{l}\text { Canal do Conselho } \\
\text { Missionário Indigenis- } \\
\text { ta }\end{array}$ \\
\hline 2016 & Mujica, Pepe & $\begin{array}{l}\text { Diálogos del Buen Vivir con } \\
\text { José Mujica }\end{array}$ & $\begin{array}{l}\text { Mujica apresenta suas visões sobre as noções de Bem } \\
\text { Viver enfatizando a necessidade de se repensar pa- } \\
\text { drões de consumo e o modo de vida capitalista. O po- } \\
\text { lítico percebe as noções como modos de vida anti-con- } \\
\text { sumismo, mais simples e mais saudáveis, com respeito } \\
\text { pelos ciclos da natureza e uma maior proximidade com } \\
\text { a terra. }\end{array}$ & Uruguai & Vídeo & Canal Buen Vivir TV \\
\hline 2017 & $\begin{array}{l}\text { Alcantara, Liliane } \\
\text { Cristine Schle- } \\
\text { mer; Sampaio, } \\
\text { Carlos Alberto } \\
\text { Cioce }\end{array}$ & $\begin{array}{l}\text { Bem Viver como paradigma de } \\
\text { desenvolvimento: utopia ou al- } \\
\text { ternativa possível? }\end{array}$ & $\begin{array}{l}\text { Na América Latina, surgem abordagens de desenvolvi- } \\
\text { mento, ancoradas em paradigmas e ideologias com lar- } \\
\text { ga existência, como o "Bem Viver". No esforço de } \\
\text { identificar o que já foi publicado sobre "Bem Viver", } \\
\text { "Bien Vivir/Vivir Bien" e "Good Living", analisou-se, } \\
\text { de } 2001 \text { a } 2015,66 \text { periódicos qualificados de forma } \\
\text { articulada, por meio de estudo bibliométrico, utili- } \\
\text { zando-se como técnica de medição a lei de dispersão } \\
\text { de periódicos de Bradford. }\end{array}$ & Brasil & Artigo & $\begin{array}{l}\text { Revista D\&MA - De- } \\
\text { senvolvimento e Meio } \\
\text { Ambiente }\end{array}$ \\
\hline 2017 & $\begin{array}{l}\text { Silva de Farias, } \\
\text { Eliane; Barcellos, } \\
\text { Lusival Antonio }\end{array}$ & $\begin{array}{l}\text { Jovens indígenas Tabajara: ân- } \\
\text { coras no processo de reivindi- } \\
\text { cações na busca do bem viver } \\
\text { no século XXI }\end{array}$ & $\begin{array}{l}\text { Investiga como os jovens Tabajara são âncoras atuan- } \\
\text { tes nas atividades das aldeias, nas lutas por reinvindi- } \\
\text { cações políticas, nos processos de retomadas, nas ree- } \\
\text { laborações e propagação da cultura, ou seja, na busca } \\
\text { do Bem Viver. A metodologia de cunho qualitativo uti- } \\
\text { liza entrevistas semiestruturadas. Os resultados reve- } \\
\text { lam a força da juventude Tabajara com ações para } \\
\text { apoiar as demandas contemporâneas, mas com visões } \\
\text { profundas na preservação do ser e do viver ancestral } \\
\text { indígena. }\end{array}$ & Brasil & Artigo & $\begin{array}{l}\text { Revista Tecnologia e } \\
\text { Sociedade }\end{array}$ \\
\hline 2017 & Roque Amaro, & Desenvolvimento ou Pos- & Discute o sentido, a pertinência e a atualidade do con- & Portugal & Artigo & Cadernos de Estudos \\
\hline
\end{tabular}




\begin{tabular}{|c|c|c|c|c|c|c|}
\hline & Rogério & $\begin{array}{l}\text { Desenvolvimento? Des-Envol- } \\
\text { vimento e... Noflay! }\end{array}$ & $\begin{array}{l}\text { ceito de desenvolvimento, tendo como provocação as } \\
\text { críticas que lhe têm sido dirigidas pelos autores da cor- } \\
\text { rente do "pós-desenvolvimento". Questiona a pertinên- } \\
\text { cia do conceito de desenvolvimento na perspectiva } \\
\text { pós-desenvolvimentista. Assume-se neste artigo que a } \\
\text { atitude mais interessante é a que coloca alguns destes } \\
\text { conceitos em diálogo e em interação uns com os outros } \\
\text { (diálogo intercultural). Conclui-se propondo um diálo- } \\
\text { go inovador entre o "des-envolvimento" (sugerindo re- } \\
\text { descoberta semântica do sentido original dessa pala- } \\
\text { vra) e o "noflay" (palavra que, em língua wolof, do } \\
\text { Senegal, quer dizer "Bem Viver" ou "estar bem"), } \\
\text { como uma das propostas mais recentes para este deba- } \\
\text { te a partir de África. }\end{array}$ & & & Africanos \\
\hline 2017 & $\begin{array}{l}\text { Bezerra Figueire- } \\
\text { do, W. }\end{array}$ & $\begin{array}{l}\text { A passagem do infans ao puer } \\
\text { no sistema mundo guarani }\end{array}$ & $\begin{array}{l}\text { A educação Guarani está imbricada no sistema pala- } \\
\text { vra-alma-mundo (Teko) onde a criança se desenvolve } \\
\text { em busca de um modo de ser belo e bom (um Bem Vi- } \\
\text { ver). Os elementos que levam os Guarani a compreen- } \\
\text { der a passagem de uma fase da infância a outra (tor- } \\
\text { nar-se falante) está relacionada com a maturidade da } \\
\text { palavra-alma divina, que amadurece dentro da criança. } \\
\text { Quando esta começa a falar é entendido que a mesma } \\
\text { alcançou o momento da imposição do nome. Este perí- } \\
\text { odo do pré-natal até dois ou mais anos da criança é re- } \\
\text { pleto de cuidados, que pressupõe um sistema mundo } \\
\text { complexo, na permissão ao lúdico, e a experimentação } \\
\text { das crianças como forma de compreensão profunda do } \\
\text { processo psicomotor e do desenvolvimento cognitivo. }\end{array}$ & Brasil & Artigo & $\begin{array}{l}\text { Revista da Abordagem } \\
\text { Gestaltica: Phenome- } \\
\text { nological Studies }\end{array}$ \\
\hline 2017 & $\begin{array}{l}\text { Silva, Klaus Pe- } \\
\text { reira da; Guedes, } \\
\text { Ana Lucia }\end{array}$ & $\begin{array}{l}\text { Buen Vivir Andino: Resistência } \\
\text { e/ou alternativa ao modelo he- } \\
\text { gemônico de desenvolvimento }\end{array}$ & $\begin{array}{l}\text { Ensaio teórico que problematiza a ética do Buen Vivir } \\
\text { como forma de alternativa ao modelo hegemônico de } \\
\text { desenvolvimento que tem sido disseminado e imple- } \\
\text { mentado por organizações internacionais e corpora- } \\
\text { ções. O Buen Vivir é uma visão de mundo distinta da } \\
\text { ordem internacional liberal; fundamenta-se nas noções } \\
\text { de cosmovisão relacional e pluriverso (ESCOBAR, }\end{array}$ & Brasil & Artigo & Cadernos EBAPE.BR \\
\hline
\end{tabular}




\begin{tabular}{|c|c|c|c|c|c|c|}
\hline & & & $\begin{array}{l}\text { 2011), multiverso (MAMANI, 2010) ou ecosofia andi- } \\
\text { na (ESTERMANN, 2013). O ensaio enfatiza a impor- } \\
\text { tância de repensar, segundo uma abordagem decoloni- } \\
\text { al, o papel desempenhado pelos Estados e organiza- } \\
\text { ções governamentais internacionais no que diz respeito } \\
\text { ao desenvolvimento local. A análise crítica da literatu- } \\
\text { ra sugere a existência de múltiplas visões acerca do de- } \\
\text { senvolvimento que devem ser debatidas no âmbito de } \\
\text { estudos organizacionais. }\end{array}$ & & & \\
\hline 2017 & $\begin{array}{l}\text { Oliveros Fortiche, } \\
\text { Diana Esperanza }\end{array}$ & $\begin{array}{l}\text { Plan de vida yukpa: relaciones } \\
\text { entre el territorio y el buen vi- } \\
\text { vir }\end{array}$ & $\begin{array}{l}\text { Este artigo apresenta impressões sobre o pensamento e } \\
\text { a experiência do grupo indígena Yukpa, em Serranía } \\
\text { del Perijá na Colômbia, em torno da constituição de } \\
\text { seu Plano de Vida. A criação do Plano de Vida desse } \\
\text { grupo iniciou-se há vários anos, quando foi realizado } \\
\text { um dos primeiros diagnósticos que buscava compreen- } \\
\text { der sua situação social, política, territorial, produtiva e } \\
\text { cultural. O plano procura criar condições para a reali- } \\
\text { zação do Bem Viver do grupo (concepção dos povos } \\
\text { indígenas latino-americanos em contradição com o de- } \\
\text { senvolvimento). A metodologia de trabalho foi baseada } \\
\text { na prática de pesquisa-ação participante (IAP). As con- } \\
\text { clusões mostram a particularidade da noção de Bem } \\
\text { Viver para esse grupo e a relevância do território como } \\
\text { base fundamental de sua identidade, vida e trafegar. } \\
\text { Palavras-chave: plano de vida, território, boa vida, } \\
\text { yukpa, lei, cultura. }\end{array}$ & Colômbia & Artigo & Nomadas \\
\hline 2017 & $\begin{array}{l}\text { Sampaio, Carlos } \\
\text { Alberto Cioce; } \\
\text { Parks, Craig Da- } \\
\text { vid; Mantovaneli } \\
\text { Junior, Oklinger; } \\
\text { Quinlan, Robert } \\
\text { Joseph; Alcantara, } \\
\text { Liliane Cristine } \\
\text { Schlemer }\end{array}$ & $\begin{array}{l}\text { Bem viver para a proxima gera- } \\
\text { ção: entre subjetividade e bem } \\
\text { comum a partir da perspectiva } \\
\text { da ecossocioeconomia }\end{array}$ & $\begin{array}{l}\text { Ensaio cujo objetivo é dialogar sobre o tema do BV, } \\
\text { relevando o interesse das gerações futuras, a partir da } \\
\text { relação dialética entre subjetividade e bem comum e } \\
\text { da complementaridade entre a dinâmica entre ser hu- } \\
\text { mano e natureza. A discussão remete à visão ecocêntri- } \\
\text { ca, em que sugere que o sistema social está interconec- } \\
\text { tado ao ecológico, sobretudo na ocasião em que se } \\
\text { considera a produção do BV para gerações futuras. } \\
\text { Subjetividade e bem comum podem se reconciliar no }\end{array}$ & Brasil & Artigo & Saúde e Sociedade \\
\hline
\end{tabular}




\begin{tabular}{|c|c|c|c|c|c|c|}
\hline & & & $\begin{array}{l}\text { plano de uma esfera societária que não seja reduzida a } \\
\text { mero cálculo e em que o ser humano não deponha, } \\
\text { nem ao outro (política) nem a si (psique), na produção } \\
\text { de caminho ecossocioeconômico, o que constitui uma } \\
\text { vida humana associada que não relegue sistemicamen- } \\
\text { te o seu próprio processo de socialização. }\end{array}$ & & & \\
\hline 2017 & $\begin{array}{l}\text { Gutierrez Salinas, } \\
\text { Sandra; Guerrero } \\
\text { De la Torre, Ny- } \\
\text { dia Karina; Guti- } \\
\text { errez Becerril, } \\
\text { Jaime Rodolfo; } \\
\text { Difu, CDID Ctr } \\
\text { Documentacion } \\
\text { Invest }\end{array}$ & $\begin{array}{l}\text { Psicologia Social Comunitaria } \\
\text { y el concepto Suma Qamaña }\end{array}$ & $\begin{array}{l}\text { Ensaio sobre as repercussões psicossociais para a saú- } \\
\text { de comunitária do trabalho de intervenção da psicolo- } \\
\text { gia comunitária em sua relação com o modo de inter- } \\
\text { pretar a vida (Suma Qamaña) de certos grupos aimara. } \\
\text { Os autores utilizaram um exercício de comparação de } \\
\text { três fatores, o de Maritza Montero (2001), que enfatiza } \\
\text { o fundamento ético da psicologia comunitária, o de } \\
\text { Nila Heredia (2012), que explica o significado de } \\
\text { Suma Qamaña para o povo aimara, como conceito de } \\
\text { boa vida, e o de Fernando Huanacuni (2010) sobre a } \\
\text { cosmovisão ancestral indígena. Entre as possíveis res- } \\
\text { postas para a questão colocada, constatou-se que a éti- } \\
\text { ca no trabalho comunitário pode ocorrer por si só em } \\
\text { uma relação de afeto, onde não ocorram manipulação } \\
\text { nem abuso, mas sim o cuidado e o respeito. }\end{array}$ & Bolívia & Artigo & $\begin{array}{l}\text { EUREKA Revista Ci- } \\
\text { entifica de Psicologia }\end{array}$ \\
\hline
\end{tabular}




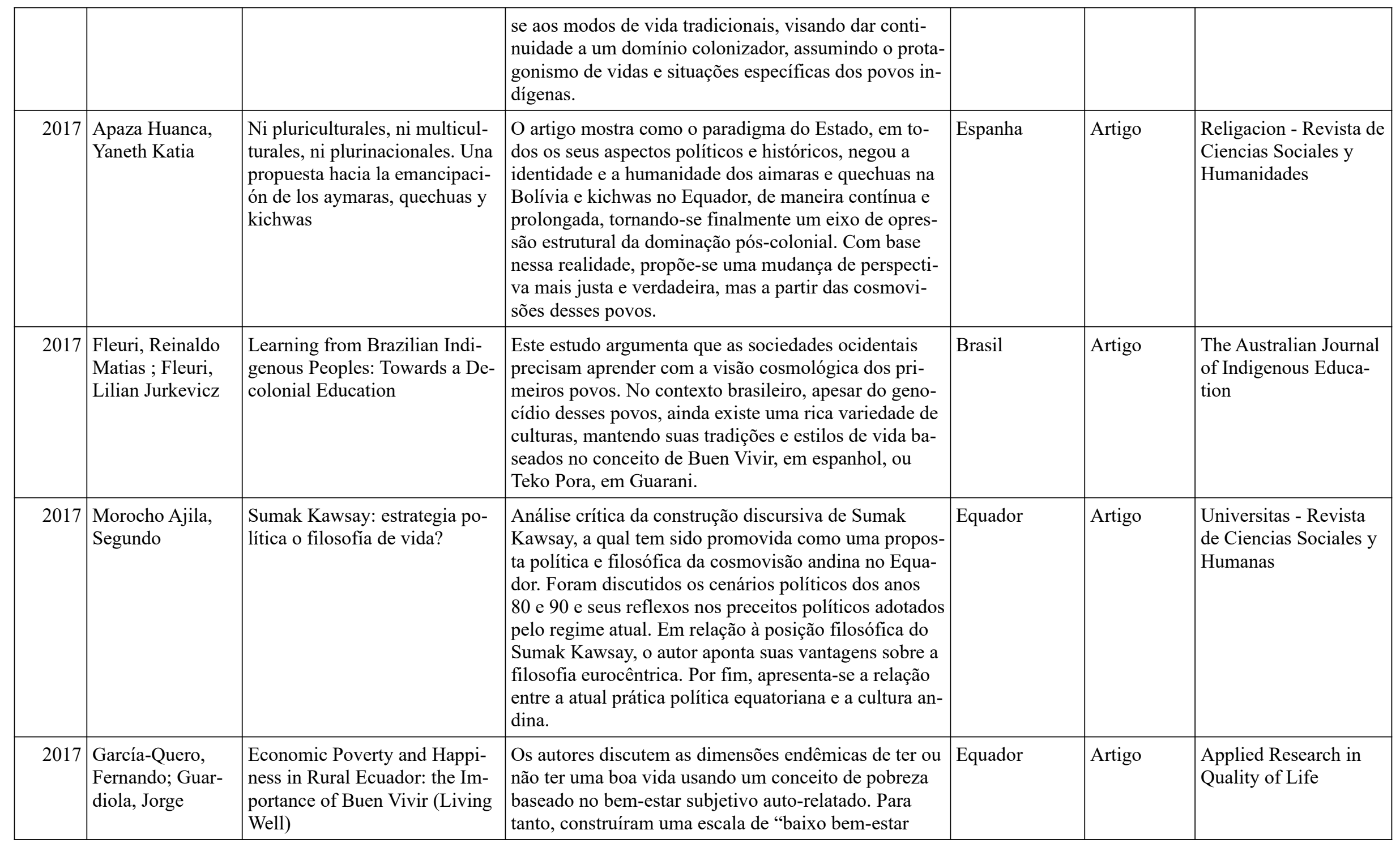




\begin{tabular}{|c|c|c|c|c|c|c|}
\hline & & & $\begin{array}{l}\text { subjetivo" e compararam com duas escalas de "baixa- } \\
\text { renda". A dimensão endêmica veio da zona rural do } \\
\text { Equador e da noção indígena de felicidade presente na } \\
\text { noção de Buen Vivir. Os resultados sugerem uma cor- } \\
\text { relação positiva entre baixa renda (BR) e baixo bem- } \\
\text { estar subjetivo. No entanto, famílias de baixa renda } \\
\text { que cultivam seus próprios alimentos e estão em uma } \\
\text { comunidade indígena tendem a reportar um nível mai- } \\
\text { or de bem-estar subjetivo. Os resultados sugerem que } \\
\text { valores altos de bem-estar subjetivo presentes em fa- } \\
\text { mílias de baixa renda podem ser explicados por com- } \\
\text { ponentes idiossincráticos da filosofia Buen Vivir. Os } \\
\text { componentes do ethos do Buen Vivir contrastados com } \\
\text { bem-estar subjetivo apontam a necessidade do desen- } \\
\text { volvimento de conceitos multidimensionais de pobreza } \\
\text { baseados no que determinados grupos étnicos conside- } \\
\text { ram bom ou ruim para o seu modo de vida específico }\end{array}$ & & & \\
\hline 2017 & $\begin{array}{l}\text { Rousseau, Malena } \\
\text { V }\end{array}$ & $\begin{array}{l}\text { Seeking buen vivir: Re-imagin- } \\
\text { ing livelihoods in the shifting } \\
\text { political economic landscape of } \\
\text { Cangahua, Ecuador. }\end{array}$ & $\begin{array}{l}\text { Nesta dissertação a pesquisadora investigou como mo- } \\
\text { radores de Cangahua, uma comunidade rural empobre- } \\
\text { cida localizada a uma hora ao norte de Quito, procu- } \\
\text { ram realizar um Buen Vivir de acordo com parâmetros } \\
\text { governamentais e ao mesmo tempo preservar sua cul- } \\
\text { tura local, em um cenário de perspectivas limitadas de } \\
\text { prosperidade econômica e intensa imersão na econo- } \\
\text { mia global. Foi utilizada uma combinação de entrevis- } \\
\text { tas com residentes e pessoas envolvidas com a comu- } \\
\text { nidade, uma pesquisa domiciliar com } 126 \text { chefes de fa- } \\
\text { mília e registros de sua observação participante para } \\
\text { examinar se e como a ideologia os programas gover- } \\
\text { namentais de Buen Viver promovem o bem-estar na } \\
\text { vida cotidiana dos residentes. Apesar de todos os desa- } \\
\text { fios para viver bem, os residentes desenvolveram e } \\
\text { mantêm várias vias de resiliência coletiva para criar } \\
\text { bem-estar e se proteger das incertezas da economia } \\
\text { instável. Esta pesquisa contribui para a literatura do }\end{array}$ & Equador & Dissertação & $\begin{array}{l}\text { University of North } \\
\text { Carolina at Chapel Hill }\end{array}$ \\
\hline
\end{tabular}




\begin{tabular}{|c|c|c|c|c|c|c|}
\hline & & & $\begin{array}{l}\text { Buen Vivir investigando os efeitos no terreno da políti- } \\
\text { ca de Buen Vivir. }\end{array}$ & & & \\
\hline 2017 & $\begin{array}{l}\text { Varea, S.; Zarago- } \\
\text { cin, S. }\end{array}$ & $\begin{array}{l}\text { Feminismo Y Buen Vivir: Uto- } \\
\text { pias Decoloniales }\end{array}$ & $\begin{array}{l}\text { As autoras discutem as relações entre as noções de } \\
\text { Bem Viver do Equador e da Bolívia com o Feminismo } \\
\text { latinoamericano. }\end{array}$ & Equador & Livro & $\begin{array}{l}\text { PYDLOS Ediciones-- } \\
\text { Universidad de Cuenca }\end{array}$ \\
\hline 2018 & $\begin{array}{l}\text { Noguera, Renato; } \\
\text { Barreto, Marcos }\end{array}$ & $\begin{array}{l}\text { Infancialização, Ubuntu e Teko } \\
\text { Porã: encruzilhadas das artes, } \\
\text { educação, ética e estética }\end{array}$ & $\begin{array}{l}\text { Os autores discutem sobre o conceito de infância e as } \\
\text { dinâmicas das ações do cotidiano escolar. Partindo do } \\
\text { pressuposto que a infância é um conceito polissêmico, } \\
\text { os autores apresentam reflexões sobre o conceito de } \\
\text { infancialização como possibilidade de rompimento } \\
\text { com as práticas atuais de experimentação da realidade, } \\
\text { a partir de orientações filosóficas africanas e indíge- } \\
\text { nas. Para tal, estabelecem diálogo com noções africa- } \\
\text { nas de Ubuntu e guarani de Teko Porã com objetivo de } \\
\text { trazer - ao âmbito educacional - as relações de cons- } \\
\text { trução do indivíduo na coletividade, reconhecendo e } \\
\text { respeitando a diversidade numa visão planificada, } \\
\text { onde os seres vivos vivem numa relação de interde- } \\
\text { pendência. Tais conceitos abandonam a perspectiva } \\
\text { colonizadora de que somos preparados para dominar, } \\
\text { enfatizando que seres humanos, animais não-humanos } \\
\text { e o meio ambiente não estão à disposição e devemos } \\
\text { tratar os seres vivos sem utilitarismo, ou seja, como } \\
\text { parte de nós. }\end{array}$ & Brasil & Artigo & $\begin{array}{l}\text { childhood \& philo- } \\
\text { sophy }\end{array}$ \\
\hline 2018 & $\begin{array}{l}\text { Martínez Novo, } \\
\text { Carmen }\end{array}$ & $\begin{array}{l}\text { Discriminación y colonialidad } \\
\text { en el Ecuador de Rafael Correa } \\
\text { (2007-2017) }\end{array}$ & $\begin{array}{l}\text { A autora examinou duas formas de discriminação con- } \\
\text { tra povos indígenas no Equador: ventriloquismo, quan- } \\
\text { do não-indígenas falam por povos indígenas, e racismo } \\
\text { público, quando as autoridades estatais usam formas } \\
\text { de repressão baseadas em humilhações típicas do perí- } \\
\text { odo colonial. O exemplo do ventriloquismo discutido é } \\
\text { o conceito de boa vida ou sumak kawsay no governo } \\
\text { do presidente Rafael Correa. Exemplos de racismo pú- } \\
\text { blico são extraídos das práticas repressivas das forças } \\
\text { de segurança do regime. É feita uma reflexão sobre o }\end{array}$ & Equador & Artigo & Alteridades \\
\hline
\end{tabular}




\begin{tabular}{|c|c|c|c|c|c|c|}
\hline & & & $\begin{array}{l}\text { papel que alguns acadêmicos da inflexão decolonial } \\
\text { desempenharam no aconselhamento e promoção das } \\
\text { políticas do regime de Correa em relação aos povos in- } \\
\text { dígenas e ao meio ambiente. Argumenta-se que, embo- } \\
\text { ra esses acadêmicos tenham apresentado o regime de } \\
\text { Correa como decolonial, suas práticas, atos ventrílo- } \\
\text { quos e repressivos têm sido baseados em um repertório } \\
\text { de ações com fortes raízes coloniais. }\end{array}$ & & & \\
\hline 2018 & Raby, Dominique & $\begin{array}{l}\text { Nuestra Madre sufre y llora. Vi- } \\
\text { olencia intrafamiliar y Buen Vi- } \\
\text { vir desde la relación con el } \\
\text { maíz en una comunidad nahua } \\
\text { de Guerrero, México }\end{array}$ & $\begin{array}{l}\text { A autora relata que a violência infrafamiliar é um pro- } \\
\text { blema frequente e de difícil superação para mulheres } \\
\text { indígenas no México. Grupos de mulheres indígenas } \\
\text { têm se organizado para promover a equidade de gêne- } \\
\text { ro dentro dos limites de suas culturas, a despeito de } \\
\text { costumes e tradições permeados pela hierarquia de gê- } \\
\text { nero. Este artigo fornece elementos de reflexão a partir } \\
\text { da análise da relação com o mundo em uma comunida- } \\
\text { de Nahua da região de Guerrero, México. Com base } \\
\text { em três relatos tradicionais, discute como o milho, } \\
\text { considerado como sujeito feminino, encarna valores } \\
\text { fundamentais de não-violência contra mulheres. Como } \\
\text { o milho forma tradicionalmente o núcleo da vida eco- } \\
\text { nômica e familiar, o seu valor diferencial altamente } \\
\text { positivo tem um potencial transformador na luta contra } \\
\text { a violência de gênero. Esse potencial é analisado no } \\
\text { estudo através de noções indígenas como a comple- } \\
\text { mentaridade e o Buen Vivir. }\end{array}$ & México & Artigo & $\begin{array}{l}\text { Relaciones. Estudios } \\
\text { de historia y sociedad }\end{array}$ \\
\hline 2018 & Gañán, R.P. & $\begin{array}{l}\text { El fuego que arde en las calles, } \\
\text { también arde en la cocina". } \\
\text { Mujeres indígenas y otras for- } \\
\text { mas de hacer política en los es- } \\
\text { pacios rurales del Buen Vivir } \\
\text { Ecuatoriano y el Vivir Bien Bo- } \\
\text { liviano] }\end{array}$ & $\begin{array}{l}\text { A autora investigou estratégias de empoderamento em- } \\
\text { pregadas por mulheres indígenas no Equador e na Bo- } \\
\text { lívia para poderem participar politicamente de um con- } \\
\text { texto no qual são pilares das estruturas e relações co- } \\
\text { munitárias. Através de uma abordagem qualitativa, a } \\
\text { autora apresenta dois casos específicos de comunida- } \\
\text { des rurais, Cuenca no Equador e Sucre na Bolívia, } \\
\text { onde foram feitas tentativas de tornar visível a resis- } \\
\text { tência que essas mulheres indígenas exercem em face }\end{array}$ & Equador & Artigo & Arenal \\
\hline
\end{tabular}




\begin{tabular}{|c|c|c|c|c|c|c|}
\hline & & & $\begin{array}{l}\text { dos papéis impostos, por um lado, a partir de um de- } \\
\text { senvolvimentismo ocidentalizado de tutelagem e, por } \\
\text { outro, de uma hierarquia de gênero dentro de sua pró- } \\
\text { pria cultura, dentro dos marcos do Buen Vivir equato- } \\
\text { riano e do Vivir Bien boliviano. Conclui-se que suas } \\
\text { estratégias de resistência e participação política ainda } \\
\text { estão presentes em todas as esferas e se tornam mais } \\
\text { notáveis a cada dia, sobretudo, na tentativa de partici- } \\
\text { par da construção de um modelo diferente de desen- } \\
\text { volvimento que privilegie a unidade familiar, os laços } \\
\text { de solidariedade e o bem comum. }\end{array}$ & & & \\
\hline 2018 & $\begin{array}{l}\text { Silva, Karen G. } \\
\text { G.; Garcia, Tami- }\end{array}$ & $\begin{array}{l}\text { Ecofeminismo e os direitos da } \\
\text { pachamama na constituição }\end{array}$ & $\begin{array}{l}\text { Neste estudo sobre o ecofeminismo as autoras apresen- } \\
\text { tam razões pelas quais consideram que é fundamental }\end{array}$ & Equador & Artigo & $\begin{array}{l}\text { XXVII Congresso Na- } \\
\text { cional do CONPEDI }\end{array}$ \\
\hline
\end{tabular}




\begin{tabular}{|c|c|c|c|c|c|c|}
\hline & res O. & equatoriana (2008) & $\begin{array}{l}\text { realizar uma aproximação entre ecologia e feminismo, } \\
\text { mais precisamente acerca dos pontos em comum entre } \\
\text { mulher e natureza na sociedade. Relacionando o ecofe- } \\
\text { minismo e o giro ecocêntrico presente na constituição } \\
\text { equatoriana de } 2008 \text {, as autoras apresentam aproxima- } \\
\text { ções entre o ecofeminismo e a cosmovisão andina do } \\
\text { "buen vivir" e os direitos da natureza presentes na } \\
\text { constituição do Equador (2008). }\end{array}$ & & & Porto Alegre \\
\hline 2018 & $\begin{array}{l}\text { Sousa, Flaviana } \\
\text { Rodrigues de }\end{array}$ & $\begin{array}{l}\text { Povos indígenas e saúde men- } \\
\text { tal: a luta pelo habitar sereno e } \\
\text { confiado }\end{array}$ & $\begin{array}{l}\text { A pesquisadora discute pontos de tensões emergidos } \\
\text { do diálogo interétnico em torno das questões de saúde } \\
\text { indígena, dando ênfase ao tema da saúde mental. De } \\
\text { um lado a perspectiva ocidental, Estado e afins, do ou- } \\
\text { tro a perspectiva dos povos originários, especialmente } \\
\text { de grupos Mbya Guarani, a partir da noção de Teko } \\
\text { Porã (modo de Bem Viver pleno em seus territórios) } \\
\text { baseada em revisão bibliográfica. Dentre os resultados, } \\
\text { destaca-se a importância central do território nos pro- } \\
\text { cessos de saúde/doença para os povos estudados. A } \\
\text { morada simbólica desses povos está em colapso e por } \\
\text { isso há um grande sofrimento mental, ilustrado por da- } \\
\text { dos epidemiológicos alarmantes quando comparados a } \\
\text { população em geral, altos índices de suicídio e consu- } \\
\text { mo prejudicial de álcool e outras drogas. Conclui-se } \\
\text { que embora não haja objeto comum entre as duas no- } \\
\text { ções perspectivas de saúde, existem pontos de articula- } \\
\text { ção entre esses mundos, por exemplo: alimentaçãa, } \\
\text { corporeidade, práticas de prevenção e cura, religião, a } \\
\text { força da palavra, a relação com os remédios da mata e } \\
\text { a natureza, o respeito à sua tradição e ao conhecimento } \\
\text { ocidental de saúde. Os povos originários vivenciam } \\
\text { cosmologias próprias o que requer direcionamentos } \\
\text { pertinentes para cada grupo, para cada cosmovisão. }\end{array}$ & Brasil & Tese & $\begin{array}{l}\text { Biblioteca Digital de } \\
\text { Teses e Dissertações da } \\
\text { USP }\end{array}$ \\
\hline 2018 & $\begin{array}{l}\text { Prestes, Clélia } \\
\text { Rosane dos San- } \\
\text { tos }\end{array}$ & $\begin{array}{l}\text { Estratégias de promoção da } \\
\text { saúde de mulheres negras: in- } \\
\text { terseccionalidade e bem viver }\end{array}$ & $\begin{array}{l}\text { Considerando a noção de Bem Viver, disseminada pela } \\
\text { Marcha das Mulheres Negras de } 2015 \text { pelo Bem Viver, } \\
\text { a pesquisadora investiga estratégias de compreensão e }\end{array}$ & Brasil & Tese & $\begin{array}{l}\text { Biblioteca Digital de } \\
\text { Teses e Dissertações da } \\
\text { USP }\end{array}$ \\
\hline
\end{tabular}




\begin{tabular}{|c|c|c|c|c|c|c|}
\hline & & & $\begin{array}{l}\text { promoção da saúde de mulheres negras, pela perspecti- } \\
\text { va dos direitos humanos e do feminismo negro, utili- } \\
\text { zando a interseccionalidade como método de análise e } \\
\text { de ação, orientada no sentido do Bem Viver. A noção } \\
\text { de Bem Viver adotada pela Marcha relaciona a saúde } \\
\text { pessoal com a saúde do grupo de pertencimento e da } \\
\text { natureza como um todo. Combinando a intersecciona- } \\
\text { lidade e o Bem Viver a pesquisadora afirma ter atingi- } \\
\text { do uma compreensão mais sofisticada da saúde, conce- } \\
\text { bendo-a como o equilíbrio harmonioso entre demandas } \\
\text { e recursos, na encruzilhada entre aspectos pessoais (or- } \\
\text { gânicos, psíquicos, energéticos e interpessoais), coleti- } \\
\text { vos, sociais, ecológicos e espirituais, no sentido da } \\
\text { saúde integral. A interseccionalidade aponta que a con- } \\
\text { cepção de saúde dessas mulheres tem relação direta } \\
\text { com uma multidimensionalidade de forças, a partir de } \\
\text { sua raça, gênero, classe, território, orientação sexual, } \\
\text { capacidades físicas e mentais, entre outras. }\end{array}$ & & & \\
\hline 2018 & $\begin{array}{l}\text { Siqueira, Gabriel; } \\
\text { Santos, Alessan- } \\
\text { dro O. }\end{array}$ & $\begin{array}{l}\text { A felicidade segundo o povo } \\
\text { Guarani Mbya: a noção de bem } \\
\text { viver }\end{array}$ & $\begin{array}{l}\text { Com base em revisão livre de literatura, os autores dis- } \\
\text { cutem sobre felicidade, qualidade de vida e bem-estar } \\
\text { tomando em consideração o modo de viver do povo } \\
\text { Guarani Mbya, o Teko Porã. Esse modo de vida privi- } \\
\text { legia aspectos coletivos da constituição subjetiva que } \\
\text { abrangem diversas dimensões da existência, como a } \\
\text { espiritual, a territorial, a afetiva, a educacional e a da } \\
\text { saúde. O Teko Porã pressupõe uma vida comunitária } \\
\text { em comunhão com a natureza, uma economia de reci- } \\
\text { procidade, a experiência cotidiana do sagrado e a ale- } \\
\text { gria de viver. A noção de bem-viver é um contraponto } \\
\text { a ideologia de felicidade promovida pelo sistema capi- } \\
\text { talista, estimulando a reflexão sobre outras formas de } \\
\text { considerar a alteridade, capazes de fomentar projetos } \\
\text { de sociedades mais justas e sustentáveis. O resgate dos } \\
\text { saberes dos povos autóctones da América Latina é uma } \\
\text { alternativa para o desenvolvimento de estratégias de }\end{array}$ & Brasil & Artigo & $\begin{array}{l}\text { Revista Acta Psicosso- } \\
\text { mática }\end{array}$ \\
\hline
\end{tabular}




\begin{tabular}{|c|c|c|c|c|c|c|}
\hline & & & $\begin{array}{l}\text { enfrentamento para lidar com o sofrimento biopsicos- } \\
\text { social gerado por hábitos de consumo excessivo e pelo } \\
\text { individualismo exacerbado. }\end{array}$ & & & \\
\hline 2018 & $\begin{array}{l}\text { Cuestas-Caza, Ja- } \\
\text { vier }\end{array}$ & $\begin{array}{l}\text { Sumak Kawsay is not Buen } \\
\text { Vivir }\end{array}$ & $\begin{array}{l}\text { O autor argumenta que Buen-Vivir não é sinônimo de } \\
\text { Sumak Kawsay, nem o Suma Qamaña das comunida- } \\
\text { des Aymara, nem o Balu Wala das comunidades Kuna } \\
\text { da América Central, nem o Ñande Reko das comunida- } \\
\text { des Guarani, nem qualquer outro termo indígena que } \\
\text { expresse uma aspiração de vida, uma utopia. Para as } \\
\text { comunidades investigadas, Sumak Kawsay é entendi- } \\
\text { do como uma "tradição recriada" que representa seu } \\
\text { projeto social de vida, sua utopia, e embora seja um } \\
\text { termo recente em seu vocabulário ele vem sendo in- } \\
\text { corporado por muitos grupos. }\end{array}$ & Equador & Artigo & $\begin{array}{l}\text { Repositorio de la Uni- } \\
\text { versidad Andina Simón } \\
\text { Bolivar }\end{array}$ \\
\hline 2018 & Rozas, German & $\begin{array}{l}\text { Decolonialidad, desde la psico- } \\
\text { logía social comunitaria }\end{array}$ & $\begin{array}{l}\text { O eixo central do livro é o conceito de colonialidade } \\
\text { na perspectiva da psicologia comunitária, enquanto pa- } \\
\text { radigma moderno dominante, que coloniza as subjeti- } \\
\text { vidades, as maneiras de pensar, ou seja, a própria exis- } \\
\text { tência. O autor reflete e discorre sobre alternativas e } \\
\text { estratégias de enfrentamento contra a naturalização } \\
\text { dos parâmetros da perspectiva hegemônica, capitalista, } \\
\text { eurocêntrica. }\end{array}$ & Chile & Livro & $\begin{array}{l}\text { Universidad Austral de } \\
\text { Chile }\end{array}$ \\
\hline 2018 & Turra, Gregory & $\begin{array}{l}\text { Nhe'e vy'aa: reflexões etno- } \\
\text { gráficas sobre o bem viver e } \\
\text { práticas cosmopolíticas entre os } \\
\text { Mbya Guarani no Sul do Brasil }\end{array}$ & $\begin{array}{l}\text { O autor aponta que em relação ao paradigma contra } \\
\text { hegemônico do Buen Vivir / Bem Viver há pouca res- } \\
\text { sonância conceitual entre os Guarani Mbya do Sul do } \\
\text { Brasil. A noção nativa de teko porã, elencada pela lite- } \\
\text { ratura e por espaços não acadêmicos a fim de apro- } \\
\text { ximá-los, apresenta-se como um horizonte distante que } \\
\text { desvia a atenção para referenciais etnológicos que es- } \\
\text { tejam próximos ao teko axy, seu polo oposto que ex- } \\
\text { prime a ideia de sofrimento e doença. Viver bem im- } \\
\text { plica, para os Mbya, em manter e buscar constante- } \\
\text { mente "o que traz a alegria pros espíritos", ou, nhe'ẽ } \\
\text { vy'aa. }\end{array}$ & Brasil & Monografia & $\begin{array}{l}\text { Universidade Federal } \\
\text { do Rio Grande Do Sul }\end{array}$ \\
\hline
\end{tabular}




\begin{tabular}{|c|c|c|c|c|c|c|}
\hline 2018 & Dussel, Enrique & Enrique Dussel - Buen Vivir & $\begin{array}{l}\text { Dussel discorre sobre as noções de Bem Viver, a partir } \\
\text { da perspectiva da filosofia da libertação, referindo-se à } \\
\text { noções de regras do universo, exigências comunitárias, } \\
\text { dentro de todo um sentido e uma ordem, num projeto } \\
\text { que se chama Buen Vivir, la vida buena. O filósofo en- } \\
\text { fatiza que as noções de Bem Viver podem ser projetos } \\
\text { alternativos para garantir a continuidade da vida na } \\
\text { terra, na contramão dos projetos extrativistas capitalis- } \\
\text { tas. }\end{array}$ & México & Vídeo & Canal C. Paizanni \\
\hline 2018 & Avila, Thiago & Canal Bem Vivendo & $\begin{array}{l}\text { Canal inaugurado em 2018, produzido pelo socialista } \\
\text { ambiental Thiago Ávila e seguido por mais de } 21 \text { mil } \\
\text { inscritos. Os vídeos do canal são pautados por noções } \\
\text { de ecossocialismo, enquanto corrente de pensamento e } \\
\text { de ação pautada na defesa ecológica do meio ambiente } \\
\text { e da luta por uma sociedade socialista, inspirada nos } \\
\text { valores de liberdade, igualdade e solidariedade. }\end{array}$ & Brasil & Vídeo & Canal Bem Vivendo \\
\hline 2019 & & $\begin{array}{l}\text { Lekil kuxlejal: Bem Viver na } \\
\text { saúde autônoma do movimento } \\
\text { zapatista }\end{array}$ & $\begin{array}{l}\text { O Exército Zapatista de Liberação Nacional (EZLN) e } \\
\text { suas bases de apoio são formados predominantemente } \\
\text { por indígenas que vivem na região de Chiapas, no } \\
\text { México. O movimento constrói uma profunda expe- } \\
\text { riência de autonomia, o que passa por diferentes di- } \\
\text { mensões da vida coletiva. Neste artigo, a autora pre- } \\
\text { tende, a partir de um trabalho de campo realizado na } \\
\text { região, ampliar a compreensão da noção de saúde au- } \\
\text { tônoma. Identificam nesse movimento modos de lidar } \\
\text { com as diferenças culturais e percebem os efeitos dire- } \\
\text { tos que essa valorização pode ter sobre a saúde das } \\
\text { pessoas. }\end{array}$ & México & Artigo & $\begin{array}{l}\text { Revista Eletrônica de } \\
\text { Comunicação, Infor- } \\
\text { mação e Inovação em } \\
\text { Saúde }\end{array}$ \\
\hline 2019 & & $\begin{array}{l}\text { La evaluación del bienestar en } \\
\text { pueblos originarios: desarrollo } \\
\text { de una escala para la comuni- } \\
\text { dad andina lickan-antay }\end{array}$ & $\begin{array}{l}\text { Baseando-se em noções de Bem Viver do Equador e } \\
\text { da Bolívia e em noções ocidentais hedônicas e eudai- } \\
\text { mônicas de bem-estar, os pesquisadores desenharam e } \\
\text { validaram um instrumento específico para medir o } \\
\text { bem-estar do povo lickan-antay (andino) do Chile. } \\
\text { Esse povo de lógica comunitária habita o Deserto do }\end{array}$ & Chile & Artigo & $\begin{array}{l}\text { Interciencia: Revista de } \\
\text { ciencia y tecnología de } \\
\text { América }\end{array}$ \\
\hline
\end{tabular}




\begin{tabular}{|c|c|c|c|c|c|c|}
\hline & & & $\begin{array}{l}\text { Atacama, o mais árido do mundo. Seu complexo siste- } \\
\text { ma de vida em proximidade com a natureza tem sofri- } \\
\text { do imensamente com o crescimento do turismo de lar- } \\
\text { ga escala e pela instalação de mineradoras transnacio- } \\
\text { nais. Considerando que o significado de bem-estar va- } \\
\text { ria de acordo com a cultura, valores e cosmovisão, os } \\
\text { autores desenvolveram uma escala para medir o bem- } \\
\text { estar desse povo como expressão decolonial do conhe- } \\
\text { cimento, com o fim de obter dados culturalmente re- } \\
\text { presentativos. Como resultado, os autores apresentam } \\
\text { uma escala de } 51 \text { itens, agrupados em dimensões de } \\
\text { equilíbrio: interno, comunitário, com a natureza, social } \\
\text { e de desenvolvimento étnico cultural lickan-antay. }\end{array}$ & & & \\
\hline 2019 & $\begin{array}{l}\text { Vallejo Real, Ivet- } \\
\text { te Rossana; Du- } \\
\text { halde Ruiz, Co- } \\
\text { rinne }\end{array}$ & $\begin{array}{l}\text { Las mujeres indígenas amazó- } \\
\text { nicas: actoras emergentes en las } \\
\text { relaciones estado - organizacio- } \\
\text { nes indígenas amazónicas, du- } \\
\text { rante el gobierno de alianza } \\
\text { país en el ecuador }\end{array}$ & $\begin{array}{l}\text { As autoras apresentam como mulheres indígenas ama- } \\
\text { zônicas têm se organizado para lutar contra injustiças, } \\
\text { reivindicar direitos e resistir a destruição de seus terri- } \\
\text { tórios, sobretudo, contra as explorações de minérios e } \\
\text { petróleo intensificadas durante os } 10 \text { anos de governo } \\
\text { de Rafael Correa e continuadas por Lenin Moreno. } \\
\text { Dentre as promessas de Buen Vivir de Alianza País, } \\
\text { havia a diretriz de substituição de um capitalismo soci- } \\
\text { almente excludente e ecologicamente catastrófico ba- } \\
\text { seada na exploração de recursos naturais, no entanto, o } \\
\text { que se assistiu nos dois mandatos de Correa foi um au- } \\
\text { mento do extrativismo petroleiro e da mineração de } \\
\text { larga escala. }\end{array}$ & Equador & Artigo & $\begin{array}{l}\text { Polis: Revista Latinoa- } \\
\text { mericana }\end{array}$ \\
\hline 2019 & Foiatto, Jordana & $\begin{array}{l}\text { Bolívia e Equador: um breve } \\
\text { estudo comparado acerca da } \\
\text { real efetivação das políticas de } \\
\text { gênero, voltadas para mulheres, } \\
\text { após as mudanças constitucio- } \\
\text { nais }\end{array}$ & $\begin{array}{l}\text { Tendo em vista a maior participação das mulheres na } \\
\text { política boliviana e equatoriana, a partir do processo } \\
\text { de mudança constitucional em ambos os países, o pre- } \\
\text { sente artigo responde a seguinte questão: quais são as } \\
\text { diferenças entre as políticas de gênero implementadas, } \\
\text { no âmbito das políticas equatorianas e bolivianas, a } \\
\text { partir das novas Constituições que entraram em vigor, } \\
\text { respectivamente, em } 2008 \text { e } 2009 \text { ? O resultado encon- } \\
\text { trado salienta que no Equador a lacuna entre imple- }\end{array}$ & Brasil & Artigo & $\begin{array}{l}\text { Portal do Centro La- } \\
\text { tino-Americano de Es- } \\
\text { tudos em Cultura }\end{array}$ \\
\hline
\end{tabular}




\begin{tabular}{|c|c|c|c|c|c|c|}
\hline & & & $\begin{array}{l}\text { mentação e efetivação das políticas de gênero é maior } \\
\text { do que na Bolívia, todavia, há pouca diferença entre os } \\
\text { Estados }\end{array}$ & & & \\
\hline 2019 & $\begin{array}{l}\text { Conselho Federal } \\
\text { de Psicologia }\end{array}$ & $\begin{array}{l}\text { Referências técnicas para atua- } \\
\text { ção de psicólogas(os) com po- } \\
\text { vos tradicionais }\end{array}$ & $\begin{array}{l}\text { O caderno reflete sobre princípios e posturas ético- } \\
\text { políticos e ontoepistemológicas para orientar a profis- } \\
\text { são junto aos povos e comunidades tradicionais, dentro } \\
\text { das seguintes perspectivas: as cosmovisões e seus sis- } \\
\text { temas simbólicos; o território e a produção de subjeti- } \\
\text { vidades; práticas comunitárias e o entendimento das } \\
\text { noções de Bem-Viver enquanto alternativas decoloni- } \\
\text { zadoras. }\end{array}$ & Brasil & Livro & $\begin{array}{l}\text { Conselho Federal de } \\
\text { Psicologia }\end{array}$ \\
\hline 2019 & $\begin{array}{l}\text { Munduruku, Da- } \\
\text { niel; Werá, Kaká }\end{array}$ & $\begin{array}{l}\text { A arte do Bem Viver: Conversa } \\
\text { com Kaká Werá }\end{array}$ & $\begin{array}{l}\text { Conversa entre os intelectuais indígenas Kaká Werá e } \\
\text { Daniel Munduruku. Werá compartilha a noção de Bem } \\
\text { Viver que aprendeu junto ao povo Guarani da aldeia } \\
\text { Krukutu, em São Paulo. Nessa visão, o Bem Viver está } \\
\text { ligado a ideia de Tekoa, um bom lugar para se viver. } \\
\text { Munduruku ratifica a visão de Werá, afirmando que as } \\
\text { noções de Bem Viver representam um contraponto a } \\
\text { sociedade de consumo. }\end{array}$ & Brasil & Vídeo & $\begin{array}{l}\text { Canal Daniel Mundu- } \\
\text { ruku }\end{array}$ \\
\hline
\end{tabular}




\section{Anexo 1 - Guia para execução de Revisões de Escopo (PRISMA-ScR)}

\begin{tabular}{|c|c|c|}
\hline \multicolumn{3}{|l|}{ Título } \\
\hline Título & 1 & Identificar o documento como sendo uma Revisão de Escopo. \\
\hline \multicolumn{3}{|r|}{ 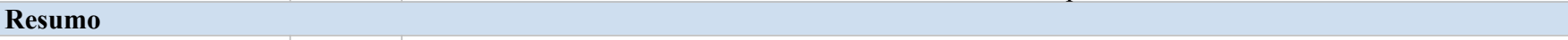 } \\
\hline Resumo estruturado & 2 & $\begin{array}{l}\text { Estrutura do resumo (quando aplicável): Contextualização, objetivos, critérios de eligibilidade, fontes } \\
\text { de evidência, métodos de mapeamento de dados, resultados e conclusões relacionadas a questão } \\
\text { principal e objetivos. }\end{array}$ \\
\hline \multicolumn{3}{|l|}{ Introdução } \\
\hline Justificativa & 3 & $\begin{array}{l}\text { Descrever a justificativa para a revisão na área escolhida. Explique por que as perguntas / objetivos de } \\
\text { revisão se prestam a uma abordagem de revisão de escopo. }\end{array}$ \\
\hline Objetivos & 4 & $\begin{array}{l}\text { Fornecer uma declaração explícita das questões e objetivos sendo abordados com referência aos seus } \\
\text { elementos-chave (ex: participantes, conceitos e contexto) }\end{array}$ \\
\hline \multicolumn{3}{|l|}{ Métodos } \\
\hline Protocolo e registro & 5 & $\begin{array}{l}\text { Indicar se existe um protocolo de revisão. Indicar se e onde pode ser acessado (endereço da Web); e, se } \\
\text { disponível, fornecer informações de registro, incluindo o número de registro. }\end{array}$ \\
\hline Critério de elegibilidade & 6 & $\begin{array}{l}\text { Especificar as características das fontes de evidência usadas como critérios de elegibilidade (por } \\
\text { exemplo, anos considerados, idioma e status de publicação) e forneça uma justificativa. }\end{array}$ \\
\hline Fontes de informação & 7 & $\begin{array}{l}\text { Descreva todas as fontes de informação na pesquisa (por exemplo, bancos de dados com datas de } \\
\text { cobertura e contato com os autores para identificar fontes adicionais). }\end{array}$ \\
\hline Estratégia de Busca & 8 & $\begin{array}{l}\text { Apresentar a estratégia de busca eletrônica completa para pelo menos } 1 \text { banco de dados, incluindo } \\
\text { quaisquer limites utilizados, de modo que possa ser repetido. }\end{array}$ \\
\hline Seleção de fontes & 9 & Declarar o processo de seleção de fontes de evidência \\
\hline $\begin{array}{l}\text { Processo de extração de } \\
\text { dados }\end{array}$ & 10 & $\begin{array}{l}\text { Descrever os métodos de mapeamento de dados das fontes de evidência incluídas (por exemplo, } \\
\text { formulários ou formulários calibrados que foram testados pela equipe antes de seu uso, e se os gráficos } \\
\text { de dados foram feitos independentemente ou em duplicado) }\end{array}$ \\
\hline $\begin{array}{l}\text { Especificar as variáves } \\
\text { relacionadas aos dados }\end{array}$ & 11 & $\begin{array}{l}\text { Listar e definir todas as variáveis para as quais dados foram coletados e quaisquer suposições e } \\
\text { simplificações feitas. }\end{array}$ \\
\hline $\begin{array}{l}\text { Avaliação crítica de } \\
\text { fontes individuais de } \\
\text { evidência }\end{array}$ & 12 & $\begin{array}{l}\text { Se aplicável, fornecer uma justificativa para a condução de uma avaliação crítica das fontes de } \\
\text { evidência incluídas; Descrever os métodos utilizados e como essa informação foi usada em qualquer } \\
\text { síntese de dados (se apropriado). }\end{array}$ \\
\hline Síntese dos resultados & 13 & Descrever os métodos de manipulação e resumo dos dados extraídos. \\
\hline \multicolumn{3}{|l|}{ Resultados } \\
\hline $\begin{array}{l}\text { Seleção das fontes de } \\
\text { evidência }\end{array}$ & 14 & $\begin{array}{l}\text { Especificar o número de fontes de evidências selecionadas, avaliadas para elegibilidade e incluídas na } \\
\text { revisão, com motivos para exclusões em cada estágio, idealmente usando um fluxograma. }\end{array}$ \\
\hline $\begin{array}{l}\text { Características das } \\
\text { fontes de evidência }\end{array}$ & 15 & $\begin{array}{l}\text { Para cada fonte de evidência, apresentar as características que justificaram a inclusão dos dados e } \\
\text { fornecer as citações. }\end{array}$ \\
\hline $\begin{array}{l}\text { Apreciação crítica de } \\
\text { fontes de evidência }\end{array}$ & 16 & Se aplicável, apresentar dados da avaliação crítica das fontes de evidência incluídas (ver item 12). \\
\hline $\begin{array}{l}\text { Resultados } \\
\text { de cada fontéficos } \\
\text { evidência }\end{array}$ & 17 & $\begin{array}{l}\text { Para cada fonte de evidência incluída, apresente os dados relevantes que foram relacionados com as } \\
\text { perguntas e objetivos de revisão. }\end{array}$ \\
\hline Síntese dos resultados & 18 & Resumir e / ou apresentar os resultados relacionados às questões e objetivos da revisão. \\
\hline \multicolumn{3}{|l|}{ Discussão } \\
\hline Resumo das evidências & 19 & $\begin{array}{l}\text { Resumir os principais resultados (incluindo uma visão geral dos conceitos, temas e tipos de evidências } \\
\text { disponíveis), vincule-os às perguntas e objetivos da revisão e considere a relevância para os grupos- } \\
\text { chave (leitores, audiência, público). }\end{array}$ \\
\hline Limites & 20 & Discuta as limitações do processo de revisão do escopo. \\
\hline Conclusões & 21 & $\begin{array}{l}\text { Forneça uma interpretação geral dos resultados com relação às perguntas e objetivos da revisão, bem } \\
\text { como possíveis implicações e / ou próximas etapas. }\end{array}$ \\
\hline \multicolumn{3}{|l|}{ Financiamento } \\
\hline Financiamento & 22 & Descrever fontes de financiamento para as fontes e da análise de escopo. \\
\hline
\end{tabular}

